\title{
IMPLEMENTASI BAURAN PROMOSI DALAM UPAYA MENINGKATKAN VOLUME PENJUALAN PADA TOKO BANGUNAN TUNGGAL TATA DI TUBAN JAWA TIMUR
}

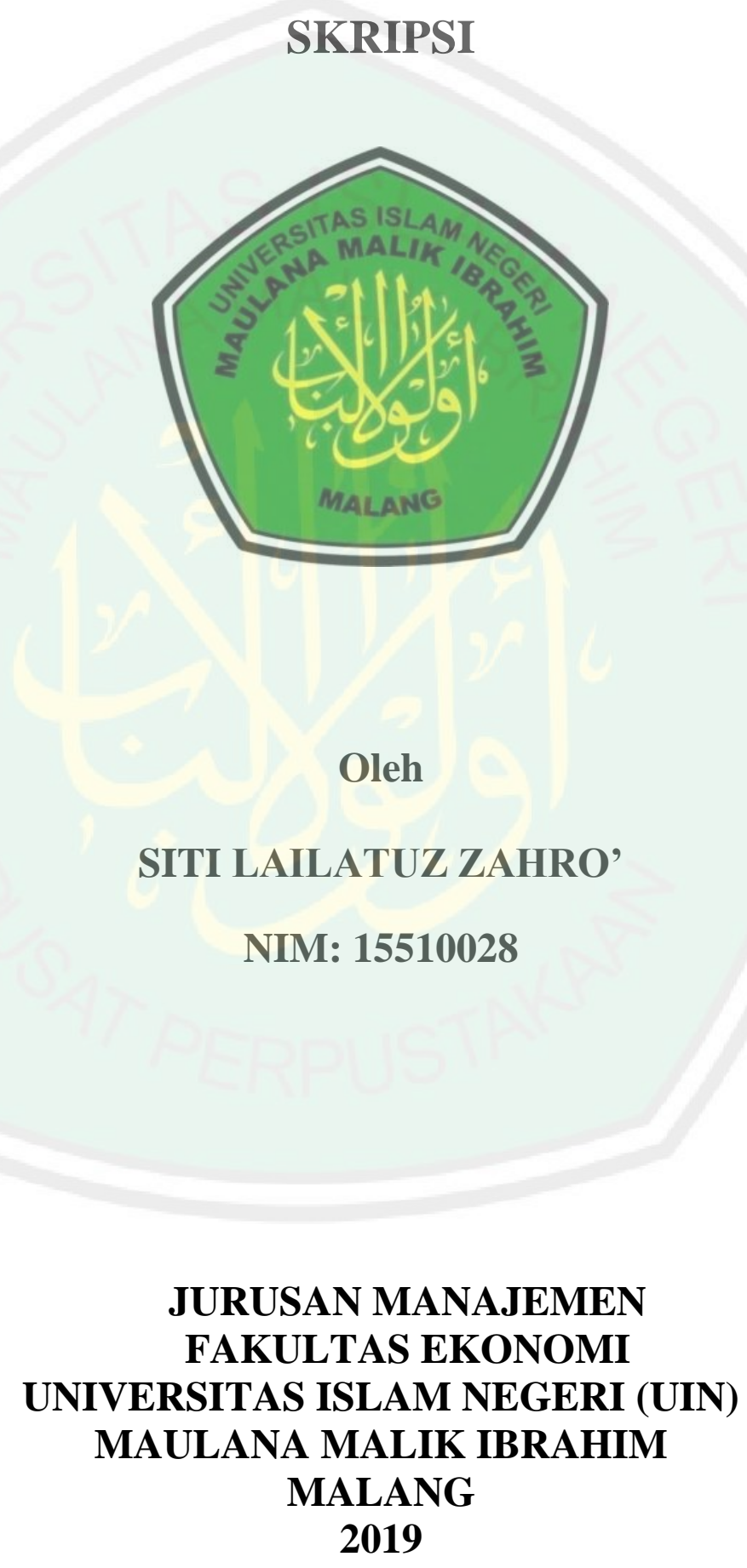




\section{IMPLEMENTASI BAURAN PROMOSI DALAM UPAYA MENINGKATKAN VOLUME PENJUALAN PADA TOKO BANGUNAN TUNGGAL TATA DI TUBAN JAWA TIMUR}

\section{SKRIPSI}

Diajukan Kepada:

Universitas Islam Negeri (UIN) Maulana Malik Ibrahim Malang

Untuk Memenuhi Salah Satu Persyaratan

Dalam Memperoleh Gelar Sarjana Ekonomi (SE)

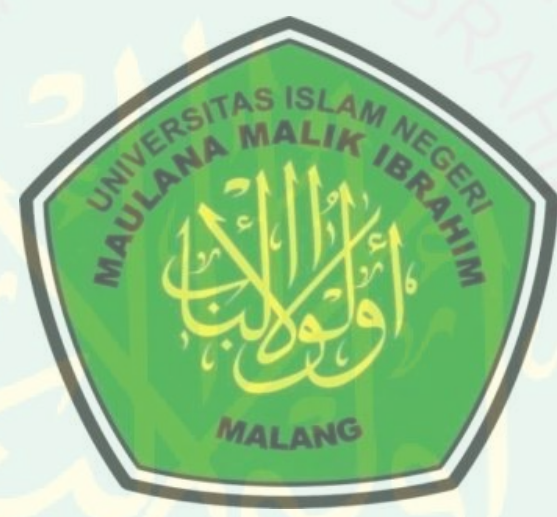

Oleh

SITI LAILATUZ ZAHRO'

NIM: 15510028

JURUSAN MANAJEMEN

FAKULTAS EKONOMI

UNIVERSITAS ISLAM NEGERI (UIN)

MAULANA MALIK IBRAHIM

MALANG

2019 


\section{LEMBAR PERSETUJUAN}

\section{IMPLEMENTASI BAURAN PROMOSI DALAM UPAYA MENINGKATKAN VOLUME PENJUALAN}

PADA TOKO BANGUNAN TUNGGAL TATA DI TUBAN JAWA TIMUR

\section{SKRIPSI}

$\mathrm{Oleh}$

SITI LAILATUZ ZAHRO' NIM : 15510028

Telah disetujui 13 Mei 2019

Dosen Pembimbing,

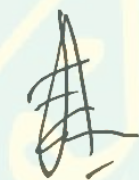

Fani Firmansyah, S.E., M.M

NIP. 197701232009121001

Mengetahui:

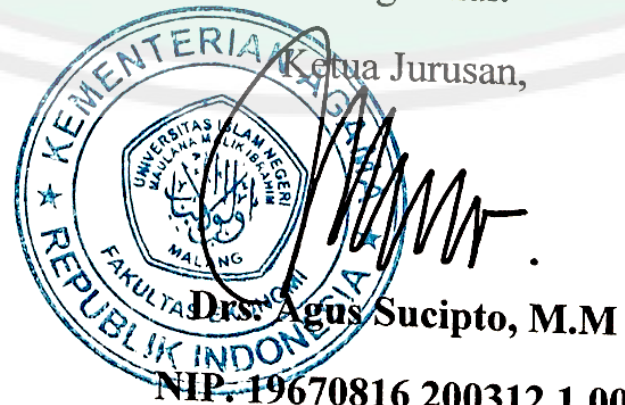

NPP-19670816 2003121001 


\section{LEMBAR PENGESAHAN}

IMPLEMENTASI BAURAN PROMOSI DALAM UPAYA MENINGKATKAN VOLUME PENJUALAN

PADA TOKO BANGUNAN TUNGGAL TATA DI TUBAN

JAWA TIMUR

\section{SKRIPSI}

Oleh

\section{SITI LAILATUZ ZAHRO' \\ NIM: 15510028}

Telah Dipertahankan di Depan Dewan Penguji Dan dinyatakan Diterima Sebagai

Salah Satu Persyaratan Untuk Memperoleh Gelar Sarjana Ekonomi (SE)

Pada 28 Mei 2019

Susunan Dewan Penguji:

Tanda Tangan

1. Ketua

Dr. Lailatul Farida, S.Sos.,M.AB

NIP. 19791010201802012192

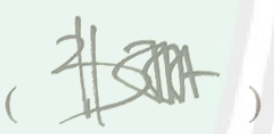

2. Dosen Pembimbing/Sekretaris

Fani Firmansyah, SE., M.M

NIP. 197701232009121003

3. Penguji Utama

Dr. H. Salim Al Idrus, M.M., M.Ag

NIP. 196201151998031001
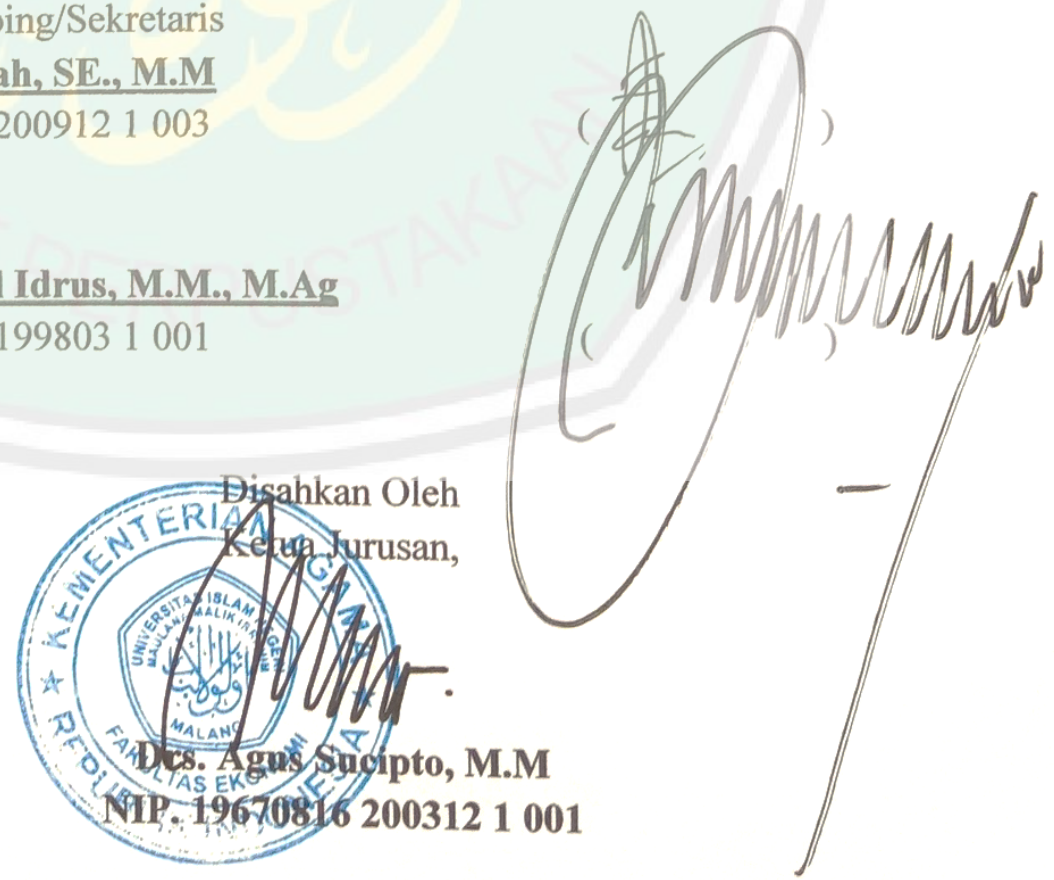


\section{SURAT PERNYATAAN}

Yang bertanda tangan di bawah ini:

$\begin{array}{ll}\text { Nama } & : \text { Siti Lailatuz Zahro' } \\ \text { NIM } & : 15510028 \\ \text { Fakultas/Jurusan } & : \text { Ekonomi/Manajemen }\end{array}$

Menyatakan bahwa "SKRIPSI" yang saya buat untuk memenuhi persyaratan kelulusan pada Jurusan Manajemen Fakultas Ekonomi Universitas Islam Negeri (UIN) Maulana Malik Ibrahim Malang, dengan judul:

IMPLEMENTASI BAURAN PROMOSI DALAM UPAYA MENINGKATKAN VOLUME PENJUALAN PADA TOKO BANGUNAN TUNGGAL TATA DI TUBAN JAWA TIMUR

Adalah hasil karya saya sendiri, bukan "duplikasi" dari karya orang lain.

Selanjutnya apabila di kemudian hari ada "klaim" dari pihak lain, bukan menjadi tanggung jawab Dosen Pembimbing dan atau pihak Fakultas Ekonomi, tetapi menjadi tanggung jawab saya sendiri.

Demikian surat pernyataan ini saya buat dengan sebenarnya dan tanpa paksaan dari siapapun.

Malang, 31 Mei 2019

Hormat saya, MIETERAI
TEMPEL 67999AFF707930602 6000

Siti Lailatuz Z.

NIM: 15510028 


\section{HALAMAN PERSEMBAHAN}

Ucapan rasa syukur kepada Allah SWT berkat rahmat-Nya saya dapat menyelesaikan skripsi ini dengan lancar.

Dengan ini, hasil dari penelitian skripsi ini saya persembahkan untuk kedua orang tua saya dan adik saya tercinta yang telah memberikan dukungan moril serta selalu memberikan doa, nasihat, dan motivasi. Tak terkecuali untuk

keluarga besar yang selalu memberikan dukungan dan doa.

Kepada guru-guru saya tercinta dan kepada sahabat serta semua temanteman saya yang telah memberikan dukungan. 


\section{MOTTO}

"Don't You Think to be The Best But You Must Think to do The Best" "Selalu Bersyukur Dalam Setiap Keadaan" 


\section{KATA PENGANTAR}

Segala puji syukur kehadirat Allah SWT, karena atas rahmat dan hidayahNya penelitian ini dapat terselesaikan dengan judul "Implementasi Bauran Promosi Dalam Upaya Meningkatkan Volume Penjualan Di Tuban Jawa Timur”.

Shalawat serta salam semoga tetap tercurahkan kepada junjungan kita Nabi besar Muhammad SAW yang telah membimbing kita dari kegelapan menuju jalan kebaikan, yaknui Din al-Islam.

Penulis menyadari bahwa dalam penulisan tugas akhir skripsi ini tidak akan berhasil dengan baik tanpa ada bimbingan dan sumbangan pemikiran dari berbagai pihak. Pada kesempatan ini penulis menyampaikan teruma kasih yang tak terhingga kepada:

1. Bapak Prof. Dr. Abdul Haris, M.Ag selaku Rektor Universitas Islam Negeri (UIN) Maulana Malik Ibrahim Malang.

2. Bapak Dr. H. Nur Asnawi, M.Ag selaku Dekan Fakultas Ekonomi Universitas Islam Negeri (UIN) Maulana Malik Ibrahim Malang.

3. Bapak Drs. Agus Sucipto, SE., MM selaku Ketua Jurusan Manajemen Universitas Islam Negeri (UIN) Maulana Malik Ibrahim Malang.

4. Bapak Fani Firmansyah, SE., MM selaku Dosen Pembimbing Skripsi.

5. Bapak/Ibu Dosen Fakultas Ekonomi Universitas Islam Negeri (UIN) Maulana Malik Ibrahim Malang.

6. Kedua Orang Tua, Bapak H. Royom dan Hj. Wasmi serta Adik Siti Shochibatul Ashfiya yang senantiasa memberikan do'a dan dukungan secara moril maupun sepiritual.

7. Pihak Internal dan eksternal Toko Bangunan Tunggal Tata yakni Pemilik dan Karyawan serta Konsumen dari Toko Bangunan Tunggal Tata.

8. KH. Yahya Dja'far dan ibu Hj. Syafi'iyah Fatah yang telah memberikan kesempatan kepada penulis untuk menuntut ilmu dan mendapat banyak pengalaman di PPP. Al-Hikmah Al-Fatimiyyah dalam menyelesaikan skripsi ini 
9. Seluruh teman-teman seperjuanganku, Ulfa, Lutfia, Imaniah, Ifa, Musyarofah, Fauziyah, Nurin, dan seluruh teman-teman jurusan Manajemen angkatan 2015 yang selalu memberi dukungan dalam menyelesaikan skripsi ini.

10. Seluruh rekan-rekan PPP. Al-Hikmah Al-Fatimiyyah, dan Mbak Hilma, Mbak Liya, Mbak Zakiya, Ifud, Hafidzah, Inas, Widad, Milkha, Nuris, Iin, Fatimah, Fika, yang selalu memberi dukungan dalam menyelesaikan skripsi ini.

11. Serta semua pihak yang tidak dapat penulis sebutkan satu-persatu yang telah membantu terselesaikannya skripsi ini.

Dalam penyusunan karya tulis ini masih banyak kekurangan dan jauh dari kesempurnaan, oleh karena itu segala kritikan dan saran yang sifatnya konstruktif dari berbagai pihak sangat diharapkan demi kesempurnaan karya tulis ini dan untuk penulis karya tulis ini selanjutnya.

Akhir kata, penulis mengharapkan semoga dari karya tulis ini dapat diambil hikmah dan manfaatnya sehingga dapat memberikan inspirasi terhadap pembaca. Semoga Allah SWT senantiasa memberikan petunjuk kepada kita semua agar apa yang kita cita-citakan terwujud.

Malang, 12 Juni 2019

Penulis 


\section{DAFTAR ISI}

HALAMAN SAMPUL DEPAN

HALAMAN JUDUL ...................................................................... i

LEMBAR PERSETUJUAN ....................................................... ii

LEMBAR PENGESAHAN ..................................................... iii

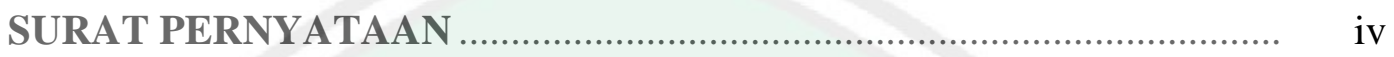

HALAMAN PERSEMBAHAN .................................................. V

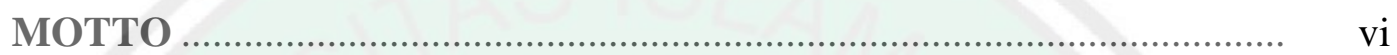

KATA PENGANTAR ........................................................................ vii

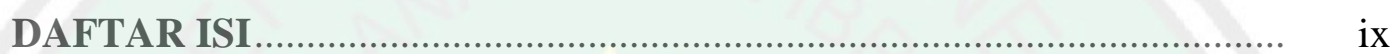

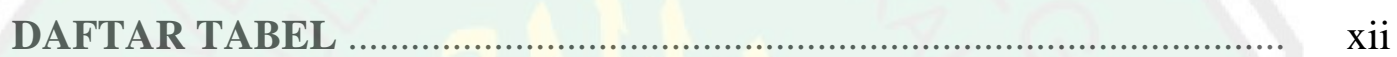

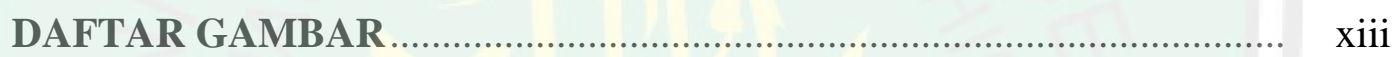

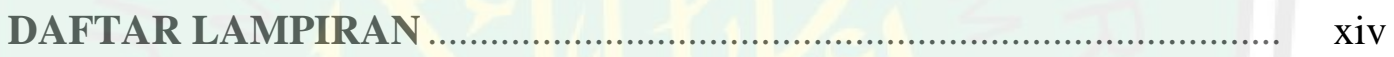

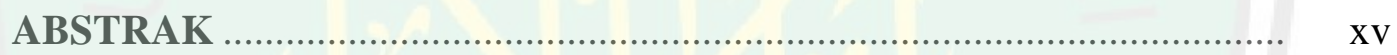

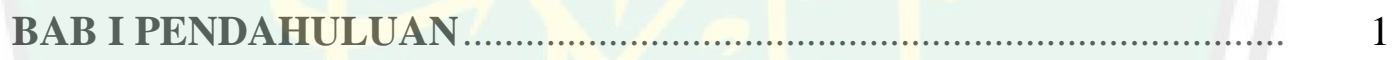

1.1 Konteks Penelitian ................................................................ 1

1.2 Fokus Penelitian .................................................................. 8

1.3 Tujuan Penelitian................................................................... 8

1.4 Manfaat Penelitian ................................................................. 8

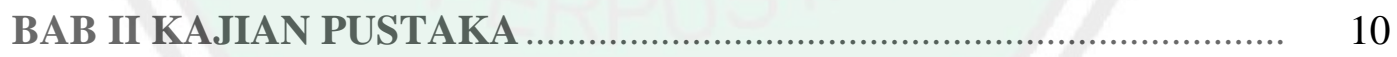

2.1 Hasil Penelitian Terdahulu ..................................................... 10

2.2 Kajian Teoritis ..................................................................... 15

2.2.1 Definisi Promosi ............................................................. 15

2.2.2 Definisi Bauran Promosi ....................................................... 17

2.2.3 Bentuk-bentuk Bauran Promosi ........................................... 18

2.2.4 Tujuan Promosi .............................................................. 41

2.2.5 Promosi dalam Pemasaran Syariah .................................... 45

2.2.6 Volume Penjualan ......................................................... 51 
2.3 Kerangka Berfikir

BAB III METODE PENELITIAN ..................................................... 53

3.1 Lokasi Penelitian .................................................................. 53

3.2 Jenis dan Pendekatan Penelitian ................................................. 53

3.3 SubyekPenelitian ............................................................. 55

3.4 Sumber Data ..................................................................... 55

3.5 Teknik Pengumpulan Data ......................................................... 56

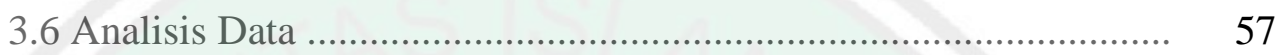

3.6.1 Tahap Analisis Data ...................................................... 58

3.6.2 Kredibilitas Data ......................................................... 58

BAB IV PAPARAN DAN PEMBAHASAN HASIL PENELITIAN ........ 61

4.1 Paparan Data Hasil Penelitian .................................................... 61

4.1.1 Sejarah Singkat Toko Bangunan Tunggal Tata ................... 61

4.1.2 Visi dan Misi ......................................................................... 62

4.1.3 Struktur Organisasi .............................................................. 62

4.1.4 Lokasi ......................................................................... 64

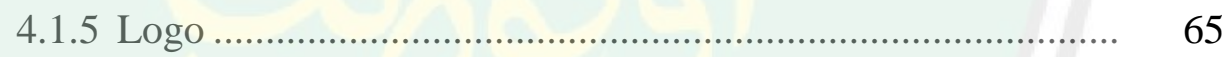

4.2 Hasil Pembahasan Implementasi Bauran Promosi ....................... 66

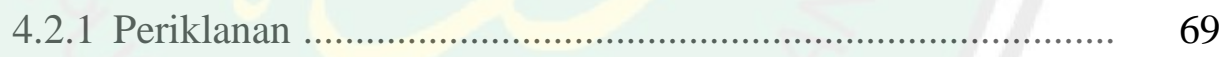

4.2.2 Penjualan Pribadi .................................................................. $\quad 74$

4.2.3 Promosi Penjualan............................................................... 80

4.2.4 Pemasaran Langsung....................................................... 85

4.2.5 Dari Mulut ke Mulut ............................................................ 89

4.2.6 Penemuan Lapangan ...................................................... 93

4.3 Implikasi dari Implementasi Bauran Promosi .............................. 96

4.3.1 Periklanan ….................................................................... 96

4.3.2 Penjualan Pribadi ................................................................. 98

4.3.3 Promosi Penjualan............................................................ 101

4.3.4 Pemasaran Langsung......................................................... 105

4.3.5 Dari Mulut ke Mulut ............................................................. 107 
4.3.6 Penemuan Lapangan ............................................................ 109

4.4 Hambatan dan Solusi dari Implementasi Bauran Promosi .............. 110

4.4.1 Periklanan ......................................................................... 110

4.4.2 Penjualan Pribadi ............................................................... 111

4.4.3 Promosi Penjualan..................................................................... 114

4.4.4 Pemasaran Langsung .............................................................. 114

4.4.5 Dari Mulut ke Mulut ............................................................ 116

4.4.6 Penemuan Lapangan .............................................................. 116

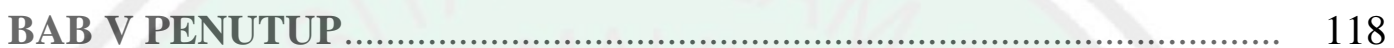

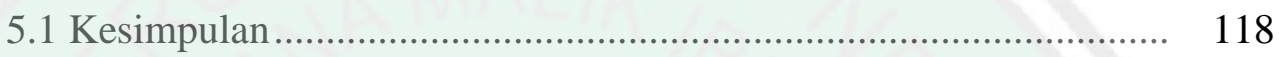

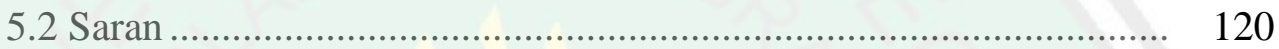

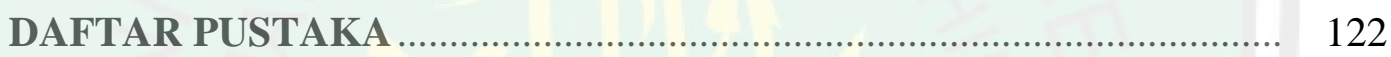

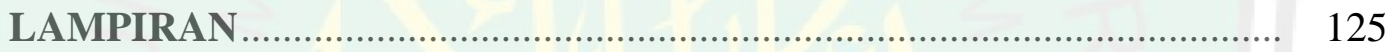




\section{DAFTAR TABEL}

Tabel 1.1 Data Pesaing Toko Tunggal Tata ................................................ 5

Tabel 1.2 Data Penjualan Toko Tunggal Tata Tahun 2015-1018 ................. 6

Tabel 2.1 Hasil-hasil Penelitian Terdahulu .................................................... 13

Tabel 4.1 Data Penjualan Toko Tunggal Tata Tahun 2015-2018................. 104 


\section{DAFTAR GAMBAR}

Gambar 4.1 Struktur Organisasi .......................................................... 63

Gambar 4.2 Lokasi Toko Bangunan Tunggal Tata .................................. 64

Gambar 4.3 Logo Toko Bangunan Tunggal Tata.................................... 65 


\section{DAFTAR LAMPIRAN}

Lampiran 1 Instrumen Penelitian

Lampiran 2 Foto Wawancara

Lampiran 3 Foto Aktivitas Toko Tunggal Tata 


\begin{abstract}
ABSTRAK
Siti Lailatuz Zahro'. 2019. SKRIPSI. Judul: “Implementasi Bauran Promosi dalam upaya Meningkatkan Volume Penjualan pada Toko Bangunan Tunggal Tata di Tuban Jawa Timur"

Pembimbing : Fani Firmansyah, SE., MM

Kata Kunci : Implementasi, Bauran Promosi, Volume Penjualan
\end{abstract}

Material merupakan bahan baku yang mendukung proses pembangunan infrastruktur yang menyebabkan munculnya bisnis dalam bidang material bangunan, maka banyak pesaing muncul sehingga diperlukan bauran promosi dalam mempertahankan maupun meningkatkan jumlah penjualan. Bauran promosi mempunyai enam elemen yaitu Advertising, Personal Selling, Sales Promotion, Direct marketing, Public Relation and Publisity, Word of Mouth. Pada saat ini toko bangunan Tunggal Tata berkembang pesat dengan jumlah volume penjualan yang meningkat, sehingga penelitian ini bertujuan untuk mengungkapkan bagaimana implementasi bauran promosi yang dilakukan oleh toko bangunan Tunggal Tata.

Penelitian ini dilakukan dengan menggunakan metode penelitian kualitatif deskriptif. Pengumpulan data dilakukan dengan teknik wawancara, dan observasi, serta dokumentasi. Dalam menganalisis data menggunakan teknik interaktive Model.

Hasil Penelitian menunjukkan bahwa toko bangunan Tunggal Tata menerapkan bauran promosi melalui lima elemen yaitu Advertising melalui media logo, Personal Salling melalui media pelayanan, Sales Promotion melalui media pemberian hadiah, Direct Marketing melalui media katalog, dan Word of Mouth. Berdasarkan temuan dilapangan, selain lima elemen dari bauran promosi tersebut, toko bangunan Tunggal Tata menggunakan media tambahan yakni memberikan keringanan pada pelanggan dalam proses pembayaran bahan bangunan dalam bentuk pemberian hutang. Oleh karena itu toko bangunan Tunggal tata berhasil dalam meningkatkan volume penjualan dalam empat tahun terakhir. 


\section{ABSTRACT}

Siti Lailatuz Zahro'. 2019, THESIS. Title: "Implementation of the Promotion Mix in an effort to Increase the Volume of Sales in the Shop Material Building Tunggal Tata in Tuban East Java"

Advisor : Fani Firmansyah, SE., MM

Keywords : Implementation, promotion mix, sale's volume

Material is the raw materials in development process favor of infrastructure that led to the business in the field of the material then a contender appeared so needed promotion mix to defend and increase the number of sales.Mix promotion has six elements, namely Advertising Personal Selling, Sales Promotion, Direct marketing, Public Relations and Publisity, Word of Mouth. At this time building material shop Tunggal Tata flourishing with the number of the volume sales increased, so that this study aims to express how implementationt promotion mix carried out by building material shop Tunggal Tata.

This Study was conducted by using the studying descriptive of qualitative. Collecting data with interview, observation, and documentation. In the analyzed data use a technique interaktive Model.

The results of study shows that Tunggal Tata of applying promotion mix through five elements, namely Advertising through the media logo, Personal Salling through the media service, Sales Promotion through the media giving a gift, Direct Marketing through the media catalog, and the Word of Mouth.Based on the findings in fact, in addition to the five elements of promotion mix, the building material shop Tunggal Tata of using the media that provide additional dispensation to customers in the payment process of building materials in the form of giving a debt. Therefore Tunggal Tata shop the succeeded in improving the volume sale in four years. 


\section{المستخلص}

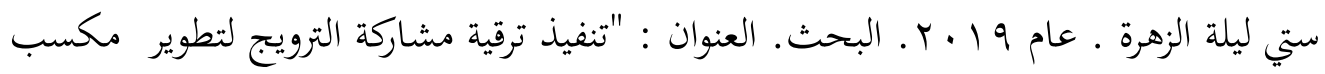

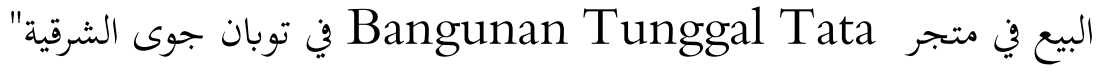
SE.,MM المشرف الكلمة الرئيسية : : تنفيذ, ترقية مشاركة الترويج, مكسب البيع

مواد البناء هي المواد الخامة التي تساعد عملية بنية التحتية تسبب نشأة شركة فيها

وكثير من المتباري الذي يبارعها. إذن يحتاج التنافس إلى ترقية مشاركة الترويج لاحتفاظ على عدد ثمرة البيع أو تطويرها. لترقية مشاركة الترويج ستة عناصر وهي إعلان, البيع الشخصي, ترويج المبيعات, التسويق المباشر , العلاقات العامة والدعاية, وكلمة الفم. قرد ازدهر متجر

تمة Bangunan Tunggal Tata ترقية مشاركة الترويج الذي يعمله متجر Bangunan Tunggal Tata ومنهج هذا البحث وصفيّ ونوعيّ. وجمُعتِت المعلومات بالمقابلة والمرصاد والتوثيق. وتحُُِلِّتُ المعلومات بطريقة تفاعُلِيّي.

تدُلّ نتيجة البحث أنّ متجر Bangunan Tunggal Tata يطبّق ترقية

مشاركة الترويج بخمسة عناصر وهي إعلان بواسطة الرمز والبيع الشخصي بواسطة الخدمة و ترويج المبيعات بواسطة الهدايا والتسويق المباشر بواسطة القائمة, وكلمة الفم. في الحقيقة هناك شيء آخر سوى الخمس وهو إعطاء الخصم على الزبون في دفعة مواد البناء بطريقة الدَّين. لذلك يجصل متجر Bangunan Tunggal Tata على تطوير مكسب البيع مدّة أربع سنوات الأخيرة. 


\section{BAB I \\ PENDAHULUAN}

\subsection{Konteks Penelitian}

Bisnis pada industri material bangunan merupakan usaha yang tidak mudah, salah satu alasannya adalah membutuhkan modal yang besar. Dalam industri ini, material bagunan memiliki prospek yang bagus untuk waktu jangka panjang karena material bangunan merupakan elemen yang sangat dibutuhkan masyarakat dalam membangun tempat tinggal. Hal tersebut juga diungkapkan oleh Dirjen Industri Agro Panggah Susanto bahwa masyarakat yang sejahtera memberikan kontribusi besar dalam perkembangan industri material bangunan karena material bangunan merupakan komponen utama dalam pembangunan infrastruktur (Kemenperin:2013). Kemudian bisnis material bangunan dapat memperoleh keuntungan besar dan barang yang dijual tidak akan mengalami penyusutan.

Industri material bangunan memiliki pesaing yang terus meningkat setiap tahunnya. Hal tersebut sesuai dengan pernyataan yang pernah diungkapkan oleh pihak pemerintah pada tahun 2015 bahwa sektor industri material bagunan terus berkembang secara signifikan di Indonesia sehingga menjadi peluang luas bagi industri pendukung material bangunan atau bisa disebut dengan pebisnis material bagunan yang masih berskala kcil/pemula. Perkembangan sektor industri material bangunan yang semakin meluas menjadikan toko material bangunan di Indonesia 
yang masih berskala kecil berusaha menerapkan strategi untuk menghadapi pesaing agar tingkat volume penjualan tetap setabil.

Jumlah volume penjualan yang terus meningkat dapat diperoleh karena memaksimalkan kinerja dan memperkuat strategi dengan beberapa bauran pemasaran. Sebagaimana yang dikatakan oleh Hasan (2013:4) bahwa pemasaran disebut sebagai proses mengidentifikasi, membangun dan mengkomunikasikan nilai, serta menjaga hubungan yang dapat memuaskan pelanggan untuk memaksimalkan keuntungan yang akan diperoleh perusahaan. Sehingga dinyatakan bahwa pemasaran memang sangat berperan dalam kegiatan bisnis. Menurut Kotler dan Amstrong (2003:78), bauran pemasaran adalah perangkat alat pemasaran taktis dan dapat dikendalikan produk, harga, distribusi, dan promosi yang dipadukan oleh para penjual untuk menghasilkan tanggapan yang diinginkan dalam pasar sasaran. Selain itu, dalam mengatasi pesaing maka harus memahami kekuatan dan kelemahan dari pesaing agar mampu menciptakan tameng dalam menghadapi para pesaing tersebut, sebagaimana yang disampaikan oleh Al Idrus (2018:85) bahwa seorang pemasar dalam mempertahankan bisnisnya harus memperhatikan oriantasi pesaing dengan memahami kelemahan dan kekuatan yang dimiliki pesaing baik itu jangka pendek maupun jangka panjang, karena pesaing yang perlu diperhatikan bukan hanya pesaing saat ini namun pesaing potensial pada masa yang akan datang.

Ketika akan dilakukannya penyampaian informasi kepada konsumen yang sesuai dengan sasaran maka formula hal yang penting diterapkan adalah bauran promosi, karena promosi merupakan cara terbaik bauran pemasaran dalam 
menyampaikan tentang produk kepada target secara efektif sehingga dapat menumbuhkan keinginan konsumen untuk melakukan pembelian. Dalam hal ini, Kotler (2005:264) menyatakan bahwa elemen-elemen bauran promosi terdiri dari lima perangkat utama, yaitu Advertising Sales Promotion, Personal Selling,Direct marketing, Public Relation and Publisity, dan. Melalui media-media promosi tersebut, para penjual dapat mengatasi pesaing-pesaing yang marak dalam bisnis di era globalisasi.

Promosi memang sangat diperlukan dalam berbisnis, dinyatakan pula pada penelitian terdahulu bahwa diperlukan promosi yang efektif untuk mengatasi pesaing dengan produk yang sejenis (Cayadi, dkk. 2013). berdasarkan teori tersebut maka para pelaku bisnis harus mampu dan memiliki pengetahuan tentang produk yang dijual agar mampu mempromosikan dengan baik. Terbatasnya pengetahuan yang dimiliki oleh para penjual dapat mengakibatkan kurang meluasnya informasi yang diterima oleh para konsumen terkait produk yang ditawarkan, sehingga berdampak pada peningkatan volume penjualan yang disebabkan karena kurang tepatnya penerapan media promosi. Pernyataan tersebut terbukti sesuai dengan kutipan penelitian terdahulu bahwa perancangan promosi sangat dibutuhkan pada jasa transportasi wisata unik di kota solo karena media promosi yang digunakan untuk memperkenalkan aset-aset negara masih kurang tepat. (Onggo, dkk. 2014). Dari penelitian-penelitian terdahulu tersebut maka bauran promosi sangat perlu dilakukan sebagai alat pemasaran untuk meningkatkan volume penjualan karena menurut Wilson (1983:45) menuturkan bahwa dengan adanya dukungan promosi dan lain-lain maka dapat 
memprakirakan volume penjualan, laba kotor, dan laba bersih yang di harapkan. Jumlah volume penjualan didapatkan dari hasil penjualan seluruh produk dalam jangka watu tertentu.

Namun, biaya juga sering menjadi kendala bagi para penjual dalam melaksanakan kegiatan promosi secara maksimal sehingga diperlukan strategi untuk menggunakan media bauran promosi yang paling efektif dan efisien dalam meningkatkan keputusan pembelian konsmen dengan biaya yang sesuai dengan budget yang dimiliki oleh perusahaan tersebut. Hal itu dibuktikan dari hasil penelitian terdahulu bahwa media promosi dibutuhkan untuk memberikan informasi kepada masyarakat tentang produk tersebut dan diperlukan dana dalam melaksanakan promosi tersebut. (Afrianti \& Yunaldi. 2012). Berdasarkan teori dan penelitian terdahulu tersebut, bahwa diperlukan media yang tepat untuk meningkatkan volume penjualan ditengah banyaknya pesaing, salah satunya adalah media promosi.

Potensi bisnis pada bidang material yang sangat besar mejadikan para pengusaha di kabupaten Tuban menjajaki bisnis material bangunan. Pada saat ini terdapat lebih dari 30 toko material yang ada di tiga kecamatan di Tuban, yakni merakurak, kerek, dan jenu. Salah satu toko material bangunan adalah toko Tunggal tata dengan pesaing yang sangat berat di dua kecamatan di Tuban sebagaimana tabel 1.1. 
Tabel 1.1

Data Pesaing Toko Tunggal Tata

\begin{tabular}{|l|l|}
\hline \multicolumn{1}{|c|}{ Alamat Toko Material } & \multicolumn{1}{c|}{ Nama Toko Material } \\
\hline Semampir, Merakurak & Sumber Family \\
\hline Senori, Merakurak & Jago \\
\hline Senori, Merakurak & Barokah Bumi \\
\hline Kec Jenu & Lebu Mas \\
\hline
\end{tabular}

Sumber: Data Toko Tunggal Tata 2019

Berdasarkan informasi awal pada tanggal 27/01/2019, pemilik toko tunggal tata yakni Bapak H. Royom menyampaikan bahwa empat toko material bangunan pada data diatas tergolong sebagai pesaing berat karena mereka menggunakan media promosi modern yakni dengan media sosial dan sistem dalam proses penjualan juga menggunakan sistem scan barcode sehingga lebih efektif dalam proses pelayanan. Sedangkan toko Tunggal Tata hanya menggunakan sistem manual dalam proses penjualan dan menggunakan promosi cara tradisional yakni penjualan pribadi melalui pelayanan yang ramah serta menjaga komunikasi yang baik dengan pelanggan, kemudianterjadi promosi dari mulut ke mulut yang dilakukan oleh pelanggan secara alamiah karena merasa puas dengan pelayanan yang diberikan oleh toko Tunggal Tata, hal tersebut disampaikan oleh beberapa pelanggan di toko Tunggal Tata pada tanggal 27/01/2019. Namun karena hanya menggunakan dua bauran promosi maka toko Tunggal Tata memiliki keterbatasan pada luasnya segmentasi pasar, segmentasi 
pasar dari toko Tunggal Tata hanya sampai pada tiga kecamatan dan belum bisa merata di kabupaten Tuban.

Sistem penjualan yang di lakukan oleh para pesaing toko Tungal Tata sesuai dengan paparan teori dan penelitian terdahulu diatas, karena menggunakan media promosi yang lebih efektif dan efisien, sementara itu toko Tunggal Tata masih menggunakan media promosi yang kurang efektif. Namun toko Tunggal Tata tetap mampu menghadapi pesaing dengan terus meningkatnya jumlah volume penjualan berdasarkan data pada tabel 1.2 yakni data penjualan lima tahun terkhir.

Tabel 1.2

Data Penjualan Toko Tunggal Tata Tahun 2015-2018

\begin{tabular}{|c|c|c|}
\hline Tahun & Penjualan & $\begin{array}{c}\text { Presentase } \\
\text { Kenaikan }\end{array}$ \\
\hline 2015 & Rp. 7.099.250.000 & $19,5 \%$ \\
\hline 2016 & Rp. 8.484.900.000 & \\
& Rp. 10.639.750.000 & $25,4 \%$ \\
2017 & Rp. 13.519.600.000 & \multirow{2}{*}{$27,1 \%$} \\
\hline 2018 & Rp. 39.013.500.000 & \\
\hline Total & Rp. 9.753.375.000 & \\
\hline Rata-rata & R. \\
\hline Sumber: Data Toko Tunggal Tata 2019
\end{tabular}

Berdasarkan uraian diatas, maka toko Tunggal Tata merupakan salah satu pebisnis yang berhasil dalam menerapkan dua bauran promosi yaitu personal salling \& word of mouth karena jumlah volume penjualan tidak pernah menurun. Hal tersebut berbeda dengan penelitian terdahulu yang di lakukan 
oleh Nel Arianty (2014) bahwa personal salling dan sales promotion tidak mempengaruhi peningkatan volume penjualan karena personal salling cenderung bergantung pada sales promotion. Selain dari penerapan dua bauran promosi tersebut, salah satu faktor yang menyebabkan toko Tunggal Tata menjadi lebih unggul dibandingkan dengan toko lain karena di awal tahun 2003 pihak toko Tunggal Tata sebagai wirausahawan mampu membaca kondisi bahwa banyak masyarakat yang memerlukan material bangunan sehingga termotivasi untuk menyediakan bahan bangunan, hal tersebut sesuai dengan pernyataan yang disampaikan oleh Al Idrus (2017:15) bahwa seorang wirausaha adalah orang yang kreatif dan inovatif. Kreatif apabila ia memiliki kemampuan untuk menciptakan sesuatu yang baru atau mengadakan sesuatu yang belum ada, sebagai misal apabila di lingkungan kampus ini memerlukan toko buku dan kita bisa mewujudkannya maka kita adalah orang yang kreatif, namun tidak bisa inovatif jika toko buku kita tidak memiliki keberbedaan dengan toko lainnya, jika kita orang inovatif maka toko buku yang kita dirikan memiliki ciri khas tersendiri, apakah itu dalam harga, kehususan bukunya, layout ruangannya, promosi penjualannya, atau yang lainnya.

Maka pada penelitian ini yang berjudul "Implementasi Bauran Promosi dalam upaya Meningkatkan Volume Penjualan pada Toko Bangunan Tunggal Tata di Tuban Jawa Timur"dilakukan untuk mengungkapkan bagaimana implementasi bauran promosi yang dilakukan oleh toko Tunggal Tata sehingga jumlah volume penjualannya dapat meningkat di setiap tahunnya. 


\subsection{Fokus Penelitian}

1. Bagaimana implementasi bauran promosi pada toko bangunan Tunggal Tata di Tuban Jawa Timur?

2. Bagaimana implikasi dari implementasi bauran promosi pada toko bangunan Tunggal Tata di Tuban Jawa Timur?

3. Apa faktor penghambat dan pendukung dari implementasi bauran promosi pada toko bangunan Tunggal Tata di Tuban Jawa Timur?

\subsection{Tujuan Penelitian}

1. Untuk mengetahui implementasi bauran promosi pada toko bangunan Tunggal Tata di Tuban Jawa Timur

2. Untuk mengetahui implikasi dari implementasi bauran promosi pada toko bangunan Tunggal Tata di Tuban Jawa Timur

3. Untuk mengetahui faktor penghambat dan pendukung dari implementasi bauran promosi pada toko bangunan Tunggal Tata di Tuban Jawa Timur

\subsection{Manfaat Penelitian}

Berikut manfaat yang di harapkan dari penelitian ini:

\section{Manfaat Teoritis}

Penulis dapat menggunakan hasil penelitian ini sebagai pembanding teoriteori yang telah dipelajari selama perkuliahan dengan penerapan teori tersebut di dunia bisnis yang nyata, yaitu penerapan teori bauran promosi pada toko Tunggal Tata. 
2. Manfaat Praktis

Sebagai ilmu tambahan bagi toko tradisional material bangunan dalam menjalankan bisnis melalui bauran promosi yang lebih efektif untuk meningkatkan volume penjualan sehingga semakin mudah untuk berkembang. 


\section{BAB II \\ KAJIAN PUSTAKA}

\subsection{Hasil Penelitian Terdahulu}

Hasil penelitian terdahulu dari Marceline Livia Hedynata \& Wirawan E.D.Radianto (2016) yang berjudul"Strategi Promosi dalam Meningkatkan Penjualan Luscious Chocolate Potato Snack" bertujuan ingin mengungkapkan strategi promosi apa yang dapat digunakan Luscious tersebut untuk meningkatkan penjualan, dan hasilnya telah terungkap bahwa luscious dapat menggunakan lima model bauran promosi yakni acara dan pengalaman, pemasaran langsung, promosi penjualan, pemasaran interaktif online, dan pemasaran dari mulut ke mulut, kelima model tersebut merupakan bauran promosi yang paling dan di butuhkan oleh perusahaan untuk meningkatkan penjualan.

Kemudian penelitian dari Jeffrey Andi Kesuma, Karim Budiono \& Bagus Qomaruzaman Ratu Edi (2015) yang berjudul "Pengaruh Bauran Promosi terhadap Volume Penjualan Holcim Solusi Rumah Bintang Jaya di Jember" berupaya untuk menguji bauran promosi yang mana yang paling perbengaruh pada volume penjualan, dan hasil penelitian menyatakan bahwa bauran yang dapat mempengaruhi volume penjualan adalah promosi penjualan, penjualan personal, dan periklanan.Sementara untuk penelitian dari Chintiya Betari Avinda, I Nyoman Sudiarta \& Ni Made Oka Karini (2016) yang berjudul "Strategi Promosi Banyuwangi sebagai Destinasi Wisata (Studi Kasus pada Dinas Kebudayaan dan 
Pariwisata)" dilakukan untuk mengungkapkan strategi promosi manakah yang digunakan destinasi wisata tersebut untuk memeratakan kunjungan wisatawan, dan hasil penelitian mengungkapkan bahwa strategi bauran promosiyang digunakan hanyalah Advertising dan direct marketing.

Penelitian juga telah dilakukan oleh Fendy Soebijanto \& Yohanes Sondang Kunto (2013) dengan judul“Analisa Efektifitas Program Promosi Top Gondola Kopi Kapal Api Ditinjau dari Peningkatan Ekuitas Merek dan Minat Beli (Studi Kasus di PT Fastrata Buana Surabaya)" tujuannya adalah untuk mengukur keefektifan program promosi yang sudah digunakan oleh top gondola kopi kapal api, dan hasilnya adalah promosi word of mouth memang sangat efektif digunakan untuk meningkatkan ekuitas merek dan minat pembeli.

Erna Areks, Muh. Nadjib \& Syaifullah Cangara (2015) melakukan penelitian dengan judul "Pengaruh Penggunaan Bauran Promosi terhadap Tingkat Kunjungan Wisatawan pada Objek Wisata Alam di Kabupaten Pangkajene dan Kepulauan" penelitian dilakukan guna untuk menguji seberapa berpengaruhnya bauran promosi terhadap tingkat kunjungan wisatawan, dan hasilnya adalah bahwa bauran promosi word of mouth memang sangat dominan mempengaruhi tingkat kunjungan wisatawan.Sementara penelitian dilakukan oleh Didik Darmadi (2013) dengan judul "Pengaruh Promosi Penjualan terhadap Penjualan (Studi Kasus PT. Astra Internasional Tbk-Tso Cabang Soetoyo Malang)" penelitian tersebut dilakukan atas dasar ingin menguji apakah bauran promosi memang berpengaruh pada tingkat penjualan, dan hasil menyatakan bahwa dengan 
meningkatkan promosi penjualan maka akan menyebabkan volume penjualan menjadi meningkat.

Merujuk pada penelitian-penelitian sebelumnya, maka penelitian ini mengembangkan peranan bauran promosi yang menitikberatkan pada fenomena yang terjadi di lokasi, sehingga diharapkan mampu mengungkapkan peningkatan volume penjualan dengan menggunakan sistem tradisional dalam penerapan bauran promosi pada toko material tersebut. 
Tabel 2.1

Hasil-hasil Penelitian Terdahulu

\begin{tabular}{|c|c|c|c|}
\hline No & Penulis, & $\begin{array}{l}\text { Metode } \\
\text { Penelitian }\end{array}$ & Hasil Penelitian \\
\hline 1. & $\begin{array}{l}\text { Strategi Promosi } \\
\text { dalam } \\
\text { Meningkatkan } \\
\text { Penjualan Luscious } \\
\text { Chocolate Potato } \\
\text { Snack, Marceline } \\
\text { Livia Hedynata \& } \\
\text { Wirawan, } \\
\text { E.D.Radianto, } 2016\end{array}$ & $\begin{array}{l}\text { Jenis penelitian } \\
\text { yang digunakan } \\
\text { adalah metode } \\
\text { kualitatif } \\
\text { dengan } \\
\text { pendekatan } \\
\text { studi kasus. }\end{array}$ & $\begin{array}{l}\text { Hasil dari penelitian ini adalah } \\
\text { bahwa untuk melakukan } \\
\text { perbaikan strategi promosi serta } \\
\text { peningkatan strategi promosi } \\
\text { maka dilakukan melalui delapan } \\
\text { elemen bauran promosi }\end{array}$ \\
\hline 2. & $\begin{array}{lr}\text { Pengaruh } & \text { Bauran } \\
\text { Promosi terhadap } \\
\text { Volume Penjualan } \\
\text { Holcim } \\
\text { Rumah Bintang Jaya } \\
\text { di Jember, Jeffrey } \\
\text { Andi Kesuma, } \\
\text { Karim Budiono \& } \\
\text { Bagus } \\
\text { Qomaruzaman Ratu } \\
\text { Edi, 2015 }\end{array}$ & $\begin{array}{l}\text { Penelitian ini } \\
\text { menggunakan } \\
\text { metode } \\
\text { kuantitatif } \\
\text { deskriptif } \\
\text { dengan empat } \\
\text { variabel. }\end{array}$ & $\begin{array}{l}\text { Hasil dari penelitian ini } \\
\text { menunjukan bahwa pengaruh } \\
\text { bauran promosi pada produk } \\
\text { konstruksi terhadap volume } \\
\text { penjualan memiliki pengaruh } \\
\text { signifikan dengan variable } \\
\text { personal selling. }\end{array}$ \\
\hline 3. & $\begin{array}{l}\text { Strategi Promosi } \\
\text { Banyuwangi sebagai } \\
\text { Destinasi } \\
\text { Wisata (Studi Kasus } \\
\text { Padar Dinas } \\
\text { Kebudayaan Dan } \\
\text { Pariwisata), } \\
\text { Chintiya Betari } \\
\text { Avinda, I Nyoman } \\
\text { Sudiarta \& Ni Made } \\
\text { Oka Karini, } 2016\end{array}$ & $\begin{array}{l}\text { Penelitian ini } \\
\text { menggunakan } \\
\text { metode } \\
\text { deskriptif } \\
\text { kualitatif. }\end{array}$ & $\begin{array}{l}\text { Hasil penelitian menunjukan } \\
\text { bahwa bauran promosi sudah } \\
\text { memberikan dampak positif } \\
\text { pengunjungan wisatawan. } \\
\text { Namun, bauran promosi } \\
\text { tersebut belum cukup efektif } \\
\text { untuk digunakan. }\end{array}$ \\
\hline 5 . & $\begin{array}{lr}\text { Analisa } & \text { Efektifitas } \\
\text { Program Promosi } \\
\text { Top Gondola Kopi } \\
\text { Kapal Api ditinjau } \\
\text { dari Peningkatan } \\
\text { Ekuitas } \text { Merek dan }\end{array}$ & $\begin{array}{l}\text { Jenis } \text { penelitian } \\
\text { yang digunakan } \\
\text { pada penelitian } \\
\text { ini adalah } \\
\text { metode } \\
\text { kuantitatif } \\
\end{array}$ & $\begin{array}{l}\text { Hasil penelitian menunjukkan } \\
\text { bahwa program promosi top } \\
\text { gondola berhasil meningkatkan } \\
\text { ekuitas merek dari segi brand } \\
\text { association dan brand } \\
\text { loyalitaas serta } \quad \text { berhasil }\end{array}$ \\
\hline
\end{tabular}




\begin{tabular}{|c|c|c|c|}
\hline & $\begin{array}{lr}\text { Minat Beli } & \text { Studi } \\
\text { Kasus pada } & \text { PT } \\
\text { Fastrata Buana di } \\
\text { Surabaya), Fendy } \\
\text { Soebijanto } \\
\text { Yohanes Sondang } \\
\text { Kunto, } 2013\end{array}$ & $\begin{array}{l}\text { dengan metode } \\
\text { statistik. }\end{array}$ & meningkatkan minat beli. \\
\hline 6. & $\begin{array}{l}\text { Pengaruh } \\
\text { Penggunaan Bauran } \\
\text { Promosi terhadap } \\
\text { Tingkat Kunjungan } \\
\text { Wisatawan pada } \\
\text { Objek Wisata Alam } \\
\text { di Kabupaten } \\
\text { Pangkajene dan } \\
\text { Kepulauan, Erna } \\
\text { Areks, Muh. Nadjib } \\
\text { \& Syaifullah } \\
\text { Cangara, } 2015\end{array}$ & $\begin{array}{l}\text { Penelitian ini } \\
\text { menggunakan } \\
\text { pendekatan } \\
\text { kuantitatif }\end{array}$ & $\begin{array}{l}\text { Hasil analisis dari penelitian } \\
\text { tersebut bahwa unsur bauran } \\
\text { promosi yang paling dominan } \\
\text { berpengaruh terhadap tingkat } \\
\text { kunjungan wisatawan pada } \\
\text { objek wisata alam di Kabupaten } \\
\text { Pangkep, yakni word of mouth } \\
\text { marketing. }\end{array}$ \\
\hline 7. & $\begin{array}{lr}\text { Pengaruh Promosi } \\
\text { Penjualan } \\
\text { Penjualan } \\
\text { Kasus PT. } & \text { Studi } \\
\text { Internasional Tba } \\
\text { Tso Cabang Soetoyo } \\
\text { Malang), Didik } \\
\text { Darmadi, 2013 }\end{array}$ & $\begin{array}{l}\text { Penelitian ini } \\
\text { menggunakan } \\
\text { penelitian } \\
\text { deskriptif. }\end{array}$ & $\begin{array}{lr}\text { Hasil dari } & \text { penelitian } \\
\text { menyatakan bahwa pengaruh } \\
\text { promosi penjualan dengan } \\
\text { volume penjualan bersifat } \\
\text { positif artinya jika biaya } \\
\text { promosi penjualan ditingkatkan } \\
\text { maka volume penjualan akan } \\
\text { mengalami peningkatan. }\end{array}$ \\
\hline 8 . & $\begin{array}{l}\text { Implementasi } \\
\text { Bauran Promosi } \\
\text { dalam rpaya } \\
\text { Meningkatkan } \\
\text { Volumer Penjualan } \\
\text { padarr Toko } \\
\text { Bangunan Tunggal } \\
\text { Tata di Tuban Jawa } \\
\text { Timur, Siti Lailatuz } \\
\text { Zahro', } 2019\end{array}$ & $\begin{array}{l}\text { Metode } \\
\text { penelitian yang } \\
\text { digunakan } \\
\text { dengan } \\
\text { pendekatan } \\
\text { kualitatif } \\
\text { deskriptif }\end{array}$ & $\begin{array}{l}\text { Hasil dari penelitian ini dapat } \\
\text { dinyatakan bahwa dalam } \\
\text { meningkatkan } \\
\text { penjualan toko Tunggal Tata } \\
\text { menggunakan lima elemen } \\
\text { bauran promosi, dan satu } \\
\text { penemuan lapangan yakni } \\
\text { sistem pelunasan barang di } \\
\text { akhir (dapat dihutang). }\end{array}$ \\
\hline
\end{tabular}

Sumber:Data diolah peneliti 


\subsection{Kajian Teoritis}

\subsubsection{Definisi Promosi}

Menurut Kotler (1999:41) Promosi disebut sebagai segala aktivitas yang dilakukan oleh penjual untuk menonjolkan kelebihan-kelebihan dari produk yang di jual dan membujuk para konsumen. Kemudian dituturkan kembali oleh Kotler dan Armstrong (2014:77) bahwa promosi merupakan suatu aktivitas yang di dalamnya terjadi komunikasi dengan menyebutkan kenunggulan produk serta membujuk pelanggan untuk membeli produk tersebut. Kotler (2003:22) mengungkapkan bahwa promosi merupakan komunikasi yang terdiri dari berbagai pesan dari pedagang yang didesain untuk menstimulasi terjadinya kesadaran, ketertarikan, dan berakhir dengan tindakan membeli yang dilakukan oleh para pelanggan terhadap produk yang tawarkan.

Sementara itu menurut Swastha (2002:237) promosi merupakan arah informasi yang dibuat agar seseorang melakukan tindakan yang menciptakan pertukaran dalam pemasaran, kemudian Swastha \& Irawan (2006:349) mempertegas kembali bahwa promosi merupakan salah satu pemasaran yang dilakukan untuk mendorong permintaan.

Sistaningrum (2002:98) mengatakan bahwa promosi merupakan kegiatan untuk memberi pengaruh pada konsumen aktual maupun konsumen potensial agar mereka melakukan pembelian terhadap produk yang dijual saat ini ataupun di masa berikutnya. Sementara, menurut Gitosudarmo (2000:237) promosi adalah aktivitas yang dilakukan penjual untuk memberi pengaruh konsumen agar 
mengenal produk yang dijual dan kemudian konsumen tersebut memiliki ketertarikan pada produk yang dijual sehingga melakukan pembelian.Sedangkan menurut Mursid (2006:95) promosi merupakan komunikasi yang persuasi, mengajak dan membujuk serta meyakinkan. Lupiyadi (2013:92) juga mendefinisikan promosi sebagai aktivitas dalam perdagangan untuk mengkomuniukasikan manfaat dari produk yang dijual dan untuk mempengaruhi pelanggan dalam kegiatan pembelian produk sesuai dengan kebutuhan. Sementara itu. Menurut Rangkuti (2009:51) promosi merupakan aktivitas perusahaan yang menyebarkan informasi agar konsumen terus mengingatnya sehingga timbul keinginan konsumen untuk mencoba dan membeli produk perusahaan.

Maka, pada intinya promosi merupakan suatu kegiatan atau aktivitas yang di dalamnya mengandung komunikasi yang mendorong seseorang untuk melakukan pembelian terhadap produk-produk yang ditawarkan. Karena menurut Simamora (2002:753) dalam promosi tersebut terjadi proses penyajian pesan-pesan yang ditunjukan untuk membantu penjualan barang dan jasa, dan promosi merupakan aktivitas pemasaran yang paling kentara serta kontroversial yang secara rutin dilakukan oleh sebuah perusahaan. Apabila promosi atau komunikasi yang kita sampaikan baik dan tepat maka akan mampu memberi pengaruh bagi para pelanggan untuk memunculkan minat beli sehingga melakukan keputusan pembelian yang nantinya akan mampu meningkatkan volume penjualan pada perusahaan tersebut. 


\subsubsection{Definisi Bauran Promosi}

Simamora (2000:756) menyebutkan bahwa istilah dari bauran promosional mengacu pada pilihan alat promosi yang digunakan dalam rangka memasarkan sebuah produk atau jasa yang pengertiannya mencakup segenap elemen dari proses komunikasi pemasaran yakni periklanan, promosi penjualan, penjualan pribadi, dan hubungan masyarakat.Sementara, Kotler (2005:264) mengungkapkan bahwa bauran promosi terdiri atas beberapa unsur yakni Advertising "merupakan penyajian melalui non personal, ide-ide, promosi produk atau jasa melalui sponsor yang dibayar", Sales Promotion "yang merupakan berbagai insentif untuk mendorong keinginan mencoba suatu produk atau membelinya pada skala jangka pendek", Public Relation and Publicity " promosi dengan berbagai program dan untuk melindungi citra perusahaaan atau produk tersebut", Personal selling “ interaksi langsung dengan calon pembeli melalui suatu presentasi dan menjawab langsung dari pesan yang telah diterima", Direct Marketing "penggunaan telepon, surat, faksimil, e-mail dan alat penghubung non personal lainnya untuk berkomunikasi dengan mendapat tanggapan langsung dari calon pembeli dan pelanggan.

Sedangkan menurut Mursid (2006:96) bahwa secara garis besar cara promosi hanya terbagi menjadi empat kelompok, diantaranya adalah Advertising, personal selling, dan publisitas, serta sales promotion. Madura (2007:273) menuturkan bahwa bauran promosi merupakan bauran metode dari promosi yang digunakan oleh perusahaan agar permintaan produk-produknya dapat meningkat. Metode yang digunakan diantaranya adalah iklan, Penjualan perorangan, dan 
promosi penjualan, serta hubungan masyarakat. Huda, dkk (2017:22) menambah ungkapan bahwa bauran promosi merupakan program yang berisi komunikasi pemasaran total sebuah perusahaan yang terdiri dari iklan, penjualan pribadi, promosi penjualan, dan hubungan masyarakat yang digunakan oleh perusahaan untuk mencapai tujuan pemasarannya.

Berdasarkan berbagai pengertian dari bauran promosi diatas, bahwa untuk melakukan promosi ada berbagai elemen diantaranya adalah periklanan, penjualan pribadi, promosi penjualan, pemasaran langsung, dan hubungan masyarakat. Elemen-elemen tersebut dapat dijadikan sebagai alat promosi, dan alat yang akan dipilih dapat disesuaikan dengan kondisi penjualan pada perusahaan.

\subsubsection{Bentuk-bentuk Promosi}

Meskipun berbagai bauran promosi memiliki fungsi yang sama, namun memiliki perbedaan berdasarkan tugas-tugas khususnya, sebagaimana yang disampaikan oleh Tjiptono (1997:222) bahwa tugas khusus dari promotion mix diantaranya adalah:

\section{Personal Selling}

Bauran promosi ini merupakan komunikasi secara tatap muka antara penjual dan calon pembeli untuk memperkenalkan produk yang dijual dan memberikan pemahaman kepada calon pembeli agar mereka mencoba dan membeli produk yang ditawarkan. Personal selling memiliki tiga sifat yaitu:personal confrontation, maknanya bahwa ada hubungan yang nyata, langsung, dan 
interaktif antara dua orang atau lebih. Kemudian sifat Cultivation, yaitu sifat yang memungkinkan adanya hubungan yang lebih dari hubungan jual beli yaitu munculnya keakraban. Dan sifat yang terakhir dari personal selling adalah response yang memiliki arti bahwa keadaan mengharuskan calon pembeli untuk mendengar, memperhatikan, dan menanggapi apa yang disampaikan oleh penjual.

Bauran promosi personal selling memiliki berbagai fungsiuntuk mendukung metode dari bauran promosi yang lain, berikut fungsi personal selling:

a. Prospecting, yaitu mencari pembeli dan kemudian menjalin hubungan baik dengan mereka

b. Targeting, demi kenyamanan pembeli maka penjual mengalokasikan waktu yang tepat

c. Comunicating, maknanya bahwa penjual selalu memberikan informasi tentang produk yang dijual kepada pembeli

d. Selling, yaitu mendekati, memaparkan dan mendemonstrasikan, mengatasi terjadinya penolakan, serta menjual produk pada pembeli

e. Servicing, untuk memberi kepuasan pada pembeli maka penjual memberikan berbagai jasa dan pelayanan

f. Informating gathering, dengan melakukan intelijen dan riset pasar

g. Allocating, merupakan penentuan pelanggan yang dituju. 
Penjual dapat melakukan tugas personal selling secara baik dengan memenuhi beberapa keriteria, diantaranya adalah:

a. Salesmanship, Penjual yang memiliki peran pada proses personal selling harus memiliki pengetahuan tentang produk yang ditawarkan, memahami seni dalam melakukan penjualan.

b. Negotiating, dalam proses penjualan produk selalu ada syarat dan ketentuan sehingga penjual harus mampu bernegosiasi kepada pelanggan.

c. Relationship marketing, dan kriteria ini yang paling penting bahwa penjual harus mampu membina dan memelihara hubungan yang baik kepada pelanggan.

Alat yang dapat digunakan pada proses promosi personal selling diantaranya adalah:
a. Presentasi penjualan
b. Pertemuan antara penjual dan pembeli
c. Program insentif yang disepakati pihak penjual dan pembeli
d. Pemberian sampel kepada calon pembeli
e. Dilakukan dalam kegiatan pameran dagang

\section{Mass Selling}

Bauran promosi ini merupakan pendekatan yang digunakan untuk menyampaikan informasi pada khalayak tentang produk yang dijualdalam satu waktu, metode ini merupakan alternatif sangat muran dan mudah untuk tersebar luas yaitu melalui dua bentuk yaitu: 
a. Periklanan: merupakan komunikasi tidak langsung yang disusun yang mampu menimbulkan rasa menyenangkan sehingga mampu mengubah pikiran seseorang untuk melakukan pembelian. Hal tersebut dapat dilakukan karena informasi yang disampaikan pada proses periklanan adalah tentang keunggulan dan keuntungan pada produk yang ditawarkan.

Alat yang dapat digunakan pada proses promosi periklanan diantaranya: iklan cetak, film, brosur, poster, selebaran, direktori, billboard, bahan auduio visual, logo atau simbul, dan lain-lain.

b. Publisistas: merupakan bentuk penyajian dan penyebaran ide tentang barang dan jasa secara personal. Bauran promosi pada bentuk ini merupakan pemanfaatan nilai-nilai berita yang terkandung pada produk sehingga mampu membangun citra produk yang bersangkutan. Dan publisitas memiliki kredibilitas yang lebih baik dibandingkan iklan.

\section{Sales Promotion}

Promosi penjualan merupakan bentuk promosi persuasi langsung karena menggunakan berbagai insentif untuk menarik pelanggan sehingga mampu meningkatkan jumlah barang yang dibeli. Melalui promosi penjualan maka penjual dapat menarik pelanggan baru, memberi pengaruh agar pelanggan mencoba produk baru, kemudian mendorong pelanggan untuk menambah jumlah barang yang dibeli, bahkan dengan promosi penjualan maka dapat mudah menyerang aktivitas promosi dari pesaing kemudian meningkatkan timbulnya 
impulse buying pada konsumen, serta mempererat hubungan penjual dengan pengecer.

Alat yang dapat digunakan pada proses promosi penjualan diantaranya adalah:

a. Undian, permainan, atau kontes

b. Hadiah

c. Produk sampel

d. Diadakan pada pameran dagang

e. Pemberian kupon

f. Tawaran pengembalian uang

g. Diskon

h. Jaminan produk

i. Dan lain-lain.

\section{Public Relations}

Promosi yang dilakukan dalam bentuk public relations ini merupakan upaya secara menyeluruh melalui adanya komunikasi untuk mempengaruhi opini, persepsi, dan keyakinan, serta sikap dari berbgai kelompok. Kelompok yang dimaksudkan adalah mereka yang terlibat dan memiliki kepentingan dalam perusahaan sehingga mempengaruhi tujuan dari perusahaan tersebut. Untuk mendukung proses pemasaran maka promosi melalui public relations dibentuk dalam seksi kusus yang disebut dengan Marketing Public Relations (MPR). Tujuan dari pembentukan seksi ini agar menyelaraskan anara kegiatan pemasaran dengan kegiatan public relations diantaranya adalah kegiatan pelucuran produk 
baru, membangun minat pada suatu kelompok produk, mempertahankan produkproduk yang bermasalah dengan masyarakat, dan lain-lain.

\section{Direct Marketing}

Promosi pada bentuk ini adalah sistem pemasaran yang bersifat interaktif. Pada promosi direct marketing, komunikasi yang terjadi dilakukan kepada konsumen individual agar tujuan dari pesan-pesan tersebut tersampaikan dan ditanggapi langsung oleh konsumen yang bersangkutan, baik melalui telepon, pos, atau dengan datang langsung ke tempat pemasar. Melalui direct marketing maka konsumen dapat memperoleh manfaat berupa penghemat waktu dalam berbelanja bahkan proses berbelanja yang dilakukan dapat bersifat rahasia. Namun teidak menutup kemungkinan melalui direct marketing dapat timbul penipuan akibat dari penjual yang agresif dan tidak bertanggung jawab sehingga mudah memperburuk citra perusahaan.

Alat yang dapat digunakan pada proses promosi direct marketing diantaranya adalah:
a. Katalog
b. Surat
c. Electronic shopping
d. Radio, megazine
e. Dan lain-lain 
Menurut Simamora (2000:756) setiap perusahaan memilih bauran promosional yang unik, tergantung pada tujuan dan kemampuan serta pasar dari perusahaan itu sendiri, sementara itu simamora menjelaskan elemen-elemen dalam promosi sebagai berikut:

\section{Periklanan}

Advertising sebagai komunikasi yang bersifat nonpribadi melalui berbagai macam media yang dibayar oleh sebuah perusahaan bisnis, atau organisasi niralaba, atau individu, yang dalam beberapa cara teridentifikasi dalam pesan periklanan dan berharap menginformasikan atau membujuk pemirsanya. Dan peruiklanan biasanya terfokus pada media massa, seperti surat kabar, televisi, dan radio, serta papan iklan.

\section{Promosi Penjualan}

Sales Promotion disebut sebagai beberapa kumpulan alat insentif, yang lebih dominan digunakan dalam waktu jangka pendek untuk memancing pembeli produk atau jasa tertentu secara lebih cepat atau dalam jumlah banyak oleh para konsumen. Aktivitas dari promosi penjualan meliputi pameran dagang, kontes, sampel, insentif perdagangan, dan kupon, yang tujuannya untuk meyakinkan orang agar mencoba produk baru, mendorong pelanggan supaya memakai produk lebih sering, dan menggerakkan pembeli potensial dari minat ke tindakan.

\section{Penjualan Pribadi}

Personal Selling penyajian lisan dalam suatu percakapan dengan calon pembeli dengan tujuan agar melakukan suatu pembelian. Dalam penjualan pribadi 
percakapan tersebut terjadi secara eksklusif, audiens penjualan pribadi dapat berupa pelanggan perorangan, pelanggan organisasi, atau perantara pemasaran.

\section{Hubungan Masyarakat}

Public Relations adalah komunikasi dan hubungan perusahaan dengan beragam jenis publiknya yang meliputi para pelanggan, pemasok, pemegang saham, karyawan, pemerintah, masyarakat umum, dan masyarakat dimana organisasi berkecimpung. Hubungan masyarakat dapat bersifat formal maupun informal.

Swastha (2002:350) mengemukaan definisi dari beberapa perangkat bauran promosi diantaranya:

\section{.1. Advertising}

Promosi ini merupakan komunikasi dalam bentuk presentasi yang bersifat non pribadi melalui berbagai alat dengan mengeluarkan sejumlah biaya, kegiatan tersebut dilakukan oleh perusahaan, lembaga, maupun secara individu.

\section{Promosi Penjualan}

Pada promosi penjualan terdapat aktivitas selain Personal selling, periklanan dan Publisitas yang dilakukan untuk mendorong terjadinya pembelian konsumen dengan pedagangsecara efektif menggunakan berbagai alat, diantaranya demonstrasi, pameran dagang, dan lain-lain.

\section{Penjualan Pribadi}

Penjualan pribadi merupakan komunikasi antar individu yang saling bertatap muka yang bertujuan untuk memunculkan dan memperbaiki hubungan pertukaran antara pembeli dan konsumen yang saling menguntungkan. 


\section{Publisitas}

Sementara itu pada elemen publisitas, promosi terjadi melalui penyebaran sejumlah informasi tentang barang ataupunu individu dan kelompok menggunakan media tanpa biaya, dan tanpa pengawasan dari sponsor.

Madura (2007:274) juga menuturkan bahwa beberapa perusahaan hanya menggunakan salah satu metode dalam mempromosikan produknya, namun agar lebih optimal dalam mempromosikan produk maka perusahaan tersebut bergantung pada karakteristik target pasar.

Berikut metode-metode promosi yang dapat digunakan:

1. Iklan

Advertising adalah presentasi penjualan nonpersonal yang dikomunikasikan dalam bentuk media atau non media dengan tujuan untuk memberi pengaruh sebagian besar pelanggan. Meskipun biasanya iklan membutuhkan biaya yang lebih mahal dibandingkan dengan metode lainnya, namun metode iklan tersebut mampu menjangkau lebih banyak pelanggan.

\section{Penjualan Perorangan}

Personal Selling merupakan presentasi penjualan bersifat peroangan yang digunakan untuk memberi pengaruh satu atau lebih pelanggan, metode ini membutuhkan usaha secara pribadi. Para tenaga penjualan peroangan yang berbasis ritel umumnya tidak menantang karena sebagian besar tenaganya 
menangani pelanggan yang telah memasuki toko dengan maksud melakukan pembelian.

\section{Promosi Penjualan}

Sales Promotion terdiridari sekumpulan aktivitas yang tujuannya untuk memberi pengaruhi pada pelanggan, cara tersebut dapat digunakan sebagai sarana yang efektif untuk mengerakkan pelanggan agar membeli produk tertentu melaui beberapa strategi berikut:

a. Pengembalian uang

b. Kupon

c. Pemberian sampel

d. Display

e. Premi

4. Hubungan Masyarakat

Public Relations merujuk kepada tindakan-tindakan yang diambil dengan tujuan menciptakan atau mempertahankan citra publik yang menguntungkan. Beberapa perusahaan mencoba untuk membangun hubungan masyarakat yang baik melalui komunikasi dengan calon pelanggan ataupun dengan masyarakat umum sehingga dapat meningkatkan citra dari suatu produk yang di tawarkan ataupun citra dari perusahaan itu sendiri.

Sementara menurut kotler \& Amstrong (2008:135) bahwa ada lima sarana untuk melakukan promosi, diantaranya:

\section{Periklanan}


Melalui iklan maka penjual akan mampu menjangkau para konsumen yang berada di berbagai wilayah dengan biaya yang rendah, selain itu iklan juga memiliki skala yang besar dalam memaparkan suatu hal yang positif tentang ukuran, popularitas dan keberhasilan penjual karena konsumen lebih memandang bahwa produk yang diiklankan tersebut memiliki jaminan yang terpercaya.

2. Penjualan pribadi

Sarana promosi ini merupakan interaksi antara penjualan dengan satu atau lebih konsumen secara pribadi, sehingga mereka dapat memeberi penilaian terkadap produk yang dijual secara cepat.

\section{Promosi Penjualan}

Promosi penjualan merupakan sarana untuk membangun preferensi merek jangka pendek, dan cenderung tidak efektif apabila digunakan pada skala jangka panjang.

\section{Hubungan Masyarakat}

Promosi dengan membangun hubungan kepada masyarakat sangat terpercaya, karena informasi yang disampaikan terlihat sangat nyata bagi para konsumen.

\section{Pemasaran Langsung}

Sarana promosi ini biasanya ditujukan kepada orang tertentu dengan bentut yang sesuai dengan konsumen tersebut, karena promosi ini bersifat nonpublik. Selain itu, pemasaran langsung bersifat interaktif karena memungkinkan terjadinya dialog antara penjual dengan konsumen yang dapat berubah sesuai dengan repson konsumen. 
Menurut Lupiyoadi (2001:108) bahwa Prangkat dari promosi mencakup beberapa aktivitas, yakni:

\section{Periklanan}

Advertising merupakan bentuk komunikasi impersonal yang digunakan oleh perusahaan barang/jasa. Tujuan dari periklanan diantaranya adalah memberikan informasi, membujuk, pengingat, dan pemantapan atau memberikan keyakinan pada konsumen.. media yang digunakan adalah:
a. Surat Kabar
b. Majalah
c. Radio
d. Televisi
e. Papan Reklame
f. Direct mail

2. Penjualan Pribadi

Personal Selling disebut sebagai elemen yang lebih lues karena penjualnya dapat secara langsung menyelaraskan penawaran yang diberikan sesuai dengan sesuatu yang dibutuhan konsumen serta perilaku masing-masing calon pembeli, kemudian dapat melihat reaksi calon pembeli terhadap penawaran yang dilontarkan oleh tenaga penjual, sehingga dapat mengadakan penyesuaian dengan calon pembeli pada saat itu juga. 


\section{Promosi Penjualan}

Sales Promotion dilakukan atas dasar untuk meningkatkan arus buarang dan jasa dari produser sampai pada penjualan akhuirnya. Promosi penjualan dapat diberikan kepada Customer, Intermediaries, dan Sales Force.

4. Hubungan Masyarakat

Public Relation merupakan salah satu kiat pemasaran yang terpenting, selain berhubungan dengan pemasok, penyalur, dan pelanggan, perusahaan juga perlu membangun hubungan denagn kumpulan kepentingan publik secara luas. Berikut program dari hubungan masyarakat:

a. Publikasi

b. Events

c. Hubungan dengan investor

d. Pameran

e. Mensponsori beberapa acara

5. Dari Mulut ke mulut

Word of Mouth sangat mempengaruhi pemasaran dibandingkan dengan aktivitas komunikasi lainnya, karena peranan konsumen dalam mempromosikan jasa tersebut sangat penting melalui pembicaraannnya kepada pelanggan lainnya tentang pengalaman dalam menerima jasa dari perusahaan tersebut.

\section{Pemasaran Langsung}

Direct Marketing adalah elemen terakhuir dalam bauran promosi, area yang digunakan dalam pemasaran langsung terdiri dari: 
a. Direct mail

b. Mail order

c. Direct response

d. Direct selling

e. Telemarketing

f. Digital marketing

Sementara itu, bauran promosi meurut kasmir (2010:156) terdiri dari empat komponen, diantaranya:

1. Periklanan

Periklanan merupakan promosi dalam bentuk gambar ataupun kata-kata yang disajikan melalui majalah, spanduk, ataupun tayangan di televisi. Untuk pelaksanaan kegiatan promosi periklanan dapat dilakukan dengan berbagai media, yaitu:
a. Pencetak brosur kemudian dapat disebarkan
b. Pemasagan spanduk di lokasi yang strategis
c. Di cantumkan pada koran atau majalah
d. Di tayangkan dalam tayangan televisi
e. Di putar pada radio

Namun, untuk menggunakan media-media tersebut dalam proses promosi maka diperlukan beberapa pertimbangan:
a. Jangkauan media yang akan digunakan
b. Konsumen yang akan dijadikan sasaran 


\section{c. Biaya yang akan dibutuhkan}

\section{Promosi Penjualan}

Bentuk promosi ini adalah dengan memberikan hadiah atau potongan harga pada barang-barang tertentu yang bertujuan untuk meningkatkan penjualan. Media yang diperlukan dalam melakukan promosi penjualan yaitu dengan memberikan diskon, kontes, ataupun sample produk. Melalui media-media tersebut dapat memberikan manfaat, yakni:

a. Mudah dalam memberikan informasi uyang dapat menarik konsumen untuk melakukan pembelian

b. Memberikan dorongan kepada konsumen untuk segera melakukan pembelian

c. Invitasi mengharapkan nasabah segera merealisasikan pembelian

\section{Publisitas}

Promosi pada bentuk ini dilakukan untuk memancing konsumen melalui berbagai kegiatan masyarakan, salah satunya adalah pameran. Kegiatan publisitas ini dapat memunculkan sisi positif penjual dihadapan konsumen sehingga sangat penting untuk diterapkan secara berkala.

\section{Penjualan Pribadi}

Promosi Peersonal Selling merupakan kegiatan komunikasi secara langsung oleh satu penjual kepada satu atau lebih konsumen dengan harapan untuk mendapatkan keberhasilan dalam melakukan penjualan. 
Berdasarkan teori yang disampaikan Hermawan (2012:72) bahwa terdapat berbagai macam elemen bauran promosi diantaranya:

\section{Periklanan/ Advertising}

Periklanan/ advertising adalah semua bentuk penyajian dan promosi nonpersonal atas ide, barang atau jasa yang dilakukan oleh perusahaan tertentu. Periklanan juga penting untuk menghubungkan konsumen yang sudah ada dan mengingatkan mereka akan alasan dalam memilih produk yang diiklankan. Konsumen yang sudah ada juga dibuat untuk tetapmenjaga hubungan dengan produk dan jasa terbaru yang tesedia bagi mereka, dengan mengingatkan keberadaan produk secara intensif

\section{Promosi Penjualan (Sales Promotion)}

Elemen berikutnya yang termasuk dalam bauran promosi adalah promosi penjualan. Promosi penjualan adalah bentuk persuasi secara langsung melalui penggunaan berbagai insentif yang dapat diatur untuk merangsang pembelian produk dengan segera dan atau berbagai insentif yang dapat meningkatkan jumlah barang yang dibeli pelanggan.

Berikut tujuan dari promosi penjualan secara umum:

a. meningkatkan permintaan dari para pengguna industry dan atau konsumen akhir

b. meningkatkan kinerja bisnis 
c. mendukung dan mengkoordinasikan kegiatan penjualan personal dan iklan

\section{Hubungan Masyarakat (Public Relation)}

Hubungan masyarakat dapat didefinisikan sebagai fungsi manajemen yang memberikan penilaian tentang beberapa hal diantaranya adalah sikap masyarakat, identitas kebijaksanaan dan prosedur dari individu atau organisasi dengan keinginan masyarakat, dan melakukan program tindakan untuk mendapatkan pengertian serta pengakuan masyarakat.

\section{Penjualan Personal (Personal Selling)}

Personal selling merupakan salah satu metode promosi untuk mencapai suatu tujuan dalam proses penjualan, dan usaha ini memerlukan lebih banyak tenaga kerja atau tenaga penjual. Personal selling adalah pemasaran produk atau jasa dimana penjual bertemu secara langsung dengan pembeli untuk menjajaki prospek adanya peluang. Penjualan personal dilakukan dengan interaksi langsung penjual kepada satu calon pembeli atau lebih guna melakukan persentasi, menjawab pertanyaan, dan menerima pesanan.

Dalam strategi pemasaran diperlukan bauran promosi yang efektif. Tiga elemen bauran pemasaran yang lain, yaitu produk, harga, dan distribusi, sangat memerlukan bauran promosi. Bauran promosi terdiri atas lima variabel meskipun dapat pula ditambahkan satu variabel lagi seperti yang dikemukakan oleh Kotler dan Keller dalam Dharmmesta (2014: 9) sebagai berikut. 


\section{Periklanan}

Periklanan merupakan promosi dalam bentuk presentasi dan promosi nonpribadi tentang ide, barang, dan jasa yang dibayar oleh sponsor tertentu. Yang dimaksud dengan sponsor dalam pengertian tersebut tidak hanya berupa perusahaan, tetapi juga lembaga-lembaga nonlaba seperti lembaga pemerintahan, perguruan tinggi, yayasan, dan sebagainya serta individu-individu.

Komunikasi yang dilakukan oleh sponsor bersifat massa karena menggunakan media massa seperti:

a. Surat kabar

b. Majalah

c. Televisi

d. Radio

e. Papan luar ruang atau baliho, dan sebagainya.

Iklan yang dipasang pada media-media tersebut dapat memberikan umpan balik kepada sponsornya (berupa tanggapan) meskipun dalam tenggang waktu tertentu atau tidak secepat penjualan tatap muka yang sifatnya langsung.

\section{Penjualan tatap muka (personal selling)}

Penjualan tatap muka terjadi melalui interaksi langsung, saling bertemu muka antara pembeli dan penjual. Komunikasi ini dilakukan antara kedua belah pihak dan bersifat individual dan atau dua arah, sehingga penjual dapat langsung memperoleh tanggapan sebagai umpan balik tentang keinginan dan kesukaan dari pembeli. Penyampaian pesan atau percakapan yang mereka lakukan sangat 
fleksibel karena dapat menyesuaikan dengan situasi yang ada. Kegiatan penjualan tatap muka ini tidak hanya terjadi di tempat pembeli saja, tetapi juga dapat dilakukan di tempat penjualan, toko atau ditempat lain.

\section{Hubungan masyarakat dan publisitas}

Hubungan masyarakat (humas) atau Public Relation (PR) dirancang untuk mempengaruhi sikap masyarakat terhadap suatu organisasi, produknya, dan kebijakannya. Sebagai kegiatan promosi, humas ini ditempatkan oleh banyak organisasi jauh dibelakang periklanan, penjualan tatap muka dan promosi penjualan.

Kegiatan humas dimaksudkan untuk membangun dan mempertahankan citra jangka panjang bagi perusahaan dari masyarakat:
a. pelanggan
b. calon pelanggan
c. pemilik
d. karyawan
e. serikat kerja
f. masyarakat local
g. pemerintah.

Untuk mengkomunikasikan pesan yang ingin disampaikan kepada masyarakat perusahan tidak menggunakan media. Beberapa kegiatan yang dapat diamasukkan kedalam humas adalah sebagai berikut. 
a. Konferensi pers untuk menyampaikan pesan tentang organisasi dari sisi yang sangat positif.

b. Publisitas produk dengan carapensponsoran untuk mempublikasi produkproduk spesifik.

c. Komunikasi korporat dengan cara mempromosikan pemahaman tentang organisasi melalui komunikasi internal dan eksternal.

d. Melobi, yaitu kegiatan mendekati dan mempengaruhi pembuat kebijakan (pemerintah) dan pembuat peraturan untuk mempromosikan atau sebaliknya, menghilangkan peraturan.

e. Counseling yaitu memberi saran kepada manajemen tentang suatu isu-isu publik, posisi dan citra perusahaan selama waktu yang tepat maupun tidak tepat. Publisitas merupakan bagian dari fungsi yang lebih luas, yaitu hubungan masyarakat, dan meliputi upaya-upaya untuk menciptakan dan mempertahankan hubungan yang menguntungkan antara organisasi dengan masyarakat, termasuk pemilik perusahaan, karyawan, lembaga pemerintahan, penyalur, serikat buruh, serta calon pembeli. Komunikasi dengan masyarakat luas melalui hubungan masyarakat ini dapat mempengaruhi kesan terhadap sebuah organisasi maupun produk atau jasa yang ditawarkan.

\section{Promosi penjualan}

Promosi penjualan merupakan kegiatan promosi selain periklanan, penjualan tatap muka, maupun publisitas dan humas. Kegiatan-kegiatan yang termasuk dalam promosi dalam penjualan ini, antara lain: 
a. peragaan

b. pertunjukan dan pameran

c. demonstrasi penggunaan barang

d. pemberian kupon

e. rabat

f. contoh produk gratis, dan sebagainya.

Biasanya kegiatan ini dilakukan bersama-sama dengan kegiatan promosi lain, dan biayanya relatif lebih murah dibandingkan periklanan dan penjualan tatap muka. Selain itu promosi penjualan juga lebih fleksibel karena dapat dilakukan setiap saat dengan biaya yang tersedia dan dimana saja.

\section{Pemasaran langsung}

Pemasaran langsung atau direct marketing merupakan suatu sistem pemasaran interaktif yang mnggunakan satu atau beberapa media periklanan untuk mempengaruhi suatu tanggapan dan/atau transaksi yang terukur dilokasi manapun yang terukur, yaitu pesanan pelanggan. Dengan kata lain, komunikasi secara langsung dilakukan ke calon pelanggan atau pelanggan yang ada atau mencari tanggapan langsung dari mereka.

kegiatan ini biasanya memanfaatkan alat-alat seperti:
a. surat
b. telepon
c. fax, e-mail
d. alat nonpribadi lainnya. 
Kemajuan teknologi komunikasi yang ada saat ini sangat mendukung kegiatan tersebut. Berbagai kegiatan yang tercakup dalam pemasaran langsung ini adalah:
a. penertiban catalog
b. surat menyurat
c. telemarketing
d. belanja secara elektronik, melalui katalog komputer yang on-line dari rumah ke toko (electronic shopping)
e. tv shopping
f. fax
g. E-mail

6. Event dan pengalaman

Banyak aktifitas yang dapat disponsori oleh perusahaan dan dapat dimanfaatkan sebagai promosi, seperti pertunjukan music, pertandingan olah raga, pertunjukan tari, perjalanan berkendara (touring), dan sebagainya. tujuan-tujuan yang ingin dicapai oleh perusahaan dalam pensponsoran aktivitas adalah:

a. Mengidentifikasi pasar sasaran menurut faktor segmentasinya atau mengidentifikasi gaya hidup pasar sasaran

b. Meningkatkan kesadaran pasar sasaran terhadap perusahaan atau nama produk

c. Meningkatkan atau memperkuat persepi pelanggan tentang asosiasi citra merek

\section{d. Meningkatkan citra perusahaan}


e. Menciptakan pengalaman dan membangkitkan perasaan

f. Memperlihatkan komitmen pada masyarakat atau pada isu-isu sosial

Kemudian, Word of mouth yang merupakan salah satu bauran promosi memiliki pengaruh pada keputusan konsumen dalam membeli produk atau jasa. Disampaikan juga oleh hasan (2010:33) bahwa promosi dari mulut ke mulut merupakan suatu pujian, rekomendasi dan komentar pelanggan tentang pengalaman yang didapatkan dari pelayanan jasa dan produk yang benar-benar mempengaruhi keputusan pelanggan untuk melakukan pembelian. Berikut manfaat dari komunikasi word of mouth:

a. Sebagai sumber informasi yang jujur yang disampaikan oleh seoran teman tanpa ada association dari penjual

b. Informasi yang disampaikan sangat kuat karena memberikan manfaat bagi yang bertanya tentang pengalaman langsung tentang produk melalui pengalaman dari teman

c. Seseorang tidak akan bergabung pada percakappan kecuali topi yang di sampaikan tersebut menarik, sehingga word of mouth disesuaikan dengan orang-orang terbaik di dalamnya.

d. Menghasilkan media iklan secara informal

e. Informasi melalui word of mouth dapat berasal dari satu sumber, tergantung seberapa kuat influencer itu menyebar dengan cepat kepada orang lain

f. Komunikasi ini tidak dibatasi oleh ruang atau kendala apapun seperti ikatan sosial, waktu, keluarga, ataupun hambatan fisik lainnya. 


\subsubsection{Tujuan Promosi}

Menurut Label (2001:56) bahwa Fungsi promosi adalah untuk meyakinkan target pelanggan bahwa barang dan jasa yang ditawarkan memiliki keunggulan yang berbeda dibandingkan para pesaing serta dapat terjadinya pertukaran yang saling memuaskan dengan pasar yang dituju melalui penyampaian organisasi atau suatu produk. Kemudian Menurut Mursid (2008: 95), tujuan promosi adalah :

1. Karena ada banyak hal mengenai perusahaan kita yang sebaiknya diketahui oleh pihak luar.

2. Karena kita ingin meningkatkan penjualan.

3. Karena kita ingin agar perusahaan dikenal sebagai perusahaan yang baik.

Sementara itu menurut Tjiptono (2008:221)mengemukakan pendapatnuya bahwa tujuan utama dari promosi adalah menginformasikan, mempengaruhi, dan membujuk, serta mengingatkan pelanggan sasaran tentang perusahaan dan bauran pemasarannya. Secara rinci ketiga tujuan promosi tersebut dapat dijabarkan sebagai berikut:

1. Menginformasikan (informing) dapat berupa:

a. Menginformasikan pasar mengenai keberadaan suatu produk baru

b. Mengenalkan cara pemakaian yang baru dari suatu produk

c. Menyampaikan perubahan harga kepada pasar

d. Menjelaskan cara kerja suatu produk,Menginformasikan jasa-jasa yang disediakan oleh perusahaan

e. Meluruskan kesan yang keliru 


\section{f. Mengurangi ketakutan atau kehawatira pembeli \\ g. Membangun citra perusahaan}

2. Membujuk pelanggan sasaran (persuading) untuk:
a. Membentuk pilihan merek
b. Mengalihkan pilihan ke merek tertentu
c. Mengubah persepsi pelanggan terhadap atribut produk
d. Mendorong pembeli untuk belanja saat itu juga
e. Mendorong pembeli untuk menerima kunjungan wiraniaga (salesman)
3. Mengingatkan (reminding), dapat terdiri atas:

a. Mengingatkan pembeli bahwa produk yang bersangkutan dibutuhkan dalam waktu dekat

b. Mengingatkan pembeli akan tempat-tempat yang menjuual produk Perusahaan

c. Membuat pembeli tetap ingat walaupun tidak ada kampanye iklan

d. Menjaga agar ingatan pertama pembeli jatuh pada produk perusahaan.

Menurut Rangkuti (2009:51), setiap perusahaan dalam melakukan kegiatan tentu mempunyai tujuan, maka promosi di lakukan berdasarkan tujuan berikut:

1. Modifikasi Tingkah Laku, yaitu berusaha untuk mengubah pendapat dan perilaku individu tersebut hingga mampu setia dengan produk yang udi tawarkan perusahaan. 
2. Memberitahu, artinya adalah promosi yang dengan cara memberikan informasi kepada pasar tentang produk yang berkaitan dengan syarat pembelian, harga, kegunaan, kualitas, keistimewaan, dan lain sebagainya. Sehingga hal tersebut mampu membantu konsumen dalam mengambil keputusan untuk membeli.

3. Membujuk, promosi yang bersifat membujuk banyak tidak disenangi masyarakat, namun kenyataannnya melalui bujukan sering digunakan agar memberi kesan positif dan pengaruh dalam waktu yang lama terhadap perilaku pembeli.

4. Mengingatkan, dengan cara mengingatkan maka diharapkan mampu mempertahankan merek produksi di hati masyarakat.

Sementara itu, menurut Simamora (2000:760) bahwa tujuan dari komponen bauran promosi adalah saling berkaitan, berikut tujuan dari promosi itu sendiri:

1. Menyediakan informasi, informas tersenut diberikan kepada pasar tentang ketersediaan barang atau jasa tertentu, bagian besar dari promosional diarahkan kepada penyedia informasi produk kepada pelanggan potensial.

2. Meningkatkan permintaan, Sebagian besar dariu promosi memiliki tujuan untuk meningkatkan permintaan dari sebuah barang dan jasa. Beberapa promosi ditujukan kepada permintaan primer, keinginan untuk suatu kategori umum produk.

3. Membedakan produk, promosional memiliki tujuan yang salah satunya adalah diferensiasi produk. Permintaan homogen berarti bahwa para 
konsumen menganggap bahwa keluaran perusahaan pada akhirnya adalah identik dengan produk pesaingnya. Perusahaan hampir tidak mempunyai kendali terhadap variabel pemasaran, seperti harga. Sebaliknya, permintaan terdiferensiasi mengidentifikasikan lebih banyak keluwesan dalam tindakantindakan strategi pemasaran seperti perubahan harga.

4. Mengaksentuasi nilai produk, tujuan dari promosi untuk menjelaskan kepemilikan yang lebih besar utilitas produk kepada para pembeli, dengan demikian mengaksentuasi nilainya dan membenarkan harga yang lebih tinggi di pasar.

5. Engenalan kebutuhan, promosi melalui suatu komunikasi dapat mengenalkan produk baru, dalam rangka untuk memicu suatu kebutuhan, contohnya adalah asuransi jiwa.

6. Pengumpulan informasi, promosi dapat membantu pencarian informasi seorang pembeli dalam mempelajari produk. Dan oeriklanan merupakan promosi yang paling efektif-biaya untuk menyebarkan informasidibandingkan elemen bauran promosi yang lain.

7. Pengevaluasian Alternatif-alternatif, pembeli dapat mengevaluasi produk atau merek melalui promosi.

8. Keputusan untuk membeli.

9. Penggunaan Produk. 


\subsubsection{Promosi dalam Pemasaran Syariah}

Dalam era bisnis saat ini, tidak dipungkiri bahwa yang dapat meningkatkan jumlah keuntungan adalah promosi. Namun, untuk mendapatkan keuntungan tersebut mengakibatkan banyak para pelaku bisnis yang melakukan perilaku menyimpang dari etika, moral, dan aturan-aturan yang telah di tetapkan, bahkan hal tersebut juga dilakukan oleh pelaku bisnis muslim.

Sedangkan menurut Huda, dkk (2017:132) bahwa pada dasarnya, promosi yang dipandang pada segi pemasaran syariah maka harus memiliki etika dan secara terbuka tentang kelebihan dan kekurangan produk yang ditawarkan karena pada intinya yaitu mengedepankan kebenaran dari produk yang di pasarkan. Perilaku tersebut merupakan bentuk pertanggung jawaban atas apa yang telah disampaikan kepada konsumen, sebagaimana firman-Nya pada surah AlMuddatstsir ayat 38:

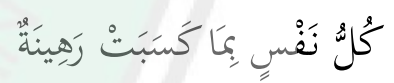

Artinya: "Tiap-tiap diri bertanggung jawab atas apa yang diperbuat". (Q.S. Al-Muddatstsir:38)

Rahman, dkk (2014) dalam Huda, dkk (2017:234) menuturkan bahwa Islam memiliki aturan ketat terhadap periklanan yang menggunakan perempuan sebagai objek untuk menarik konsumen karena perempuan memiliki daya tarik yang liar terhadap lawan jenis, dan hal tersebut sangat dilarang dalam Islam. Dan Islam sendiri memperbolehkan perempuan melakukan promosi periklanan apabila 
perempuan tersebut menutup aurat.Kemudian menurut Gunara \& Sudibya (2008:57) bahwa dalam melakukan penjualan, Rasulullah tidak pernah melebihlebihkan produk yang di jual untuk memikat para pembeli. Rasulullah menyatakan secara tegas bahwa sebagai seorang penjualan maka harus menjauhkan diri dari sumpah-sumpah yang berlebihan dan menyarankan agar orang lain tidak melakukan sumpah secara berlebihan, karena Beliau juga tidak pernah melakukan sumpah untuk melariskan dagangannya. Sebagaimana sabda Rasulullah:

"Sumpah yang diucapkan untuk melariskan perniagaan, dapat merusakan keuntungan"(HR Muslim dari Abu Hurairah Ra)

Melalui Hadis diatas, Rasulullah telah melihat di masa yang akan datang bahwa promosi yang dilakukan dengan sumpah secara berlebihan akan mengancam kelangsungan usaha para penjual itu sendiri. Hal tersebut dapat terjadi karena apabila konsumen menyadari bahwa sumpah yang kita ucapkan hanya sebuah kebohongan maka konsumen akan berhenti melakukan pembelian pada kita, bahkan tidak menutup kemungkinan konsumen tersebut akan menyebarkan informasi buruk tentang produk tersebut kepada konsumen lain sehingga diperlukan kejujuran dalam menawarkan produk tanpa adanya kalimat sumpah yang berlebihan. 
Sebagaimana Firman-Nya dalam surah Ali Imran ayat 77:

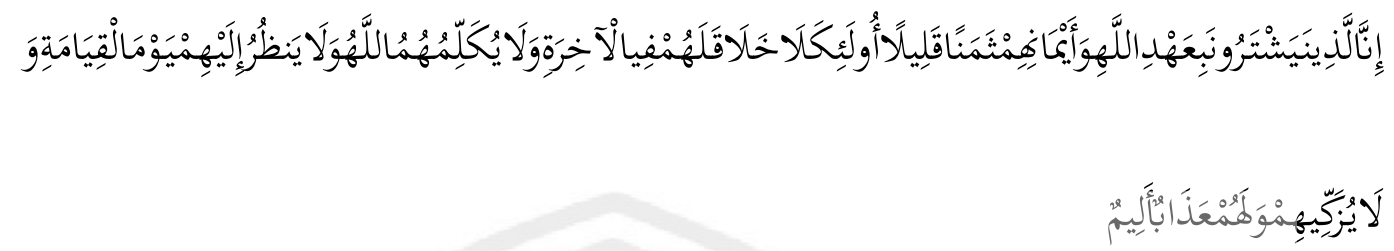

Artinya: "Sesungguhnya orang-orang yang menukar janji (nya dengan)

Allah dan sumpah-sumpah mereka dengan harga yang sedikit, mereka itu tidak mendapat bahagian (pahala) di akhirat, dan Allah tidak akan berkata-kata dengan mereka dan tidak akan melihat kepada mereka pada hari kiamat dan tidak (pula) akan mensucikan mereka. Bagi mereka azab yang pedih". (Q.S Ali-Imran:77)

Rasulullah memberikan penegasan terkait sumpah dalam melakukan promosi. Beliau melarang para penjual melakukan sumpah palsu dan menyebarkan iklan yang tidak sesuai kenyataan, karena hal tersebut dapat mengakibatkan konsumen mempunyai tingkat kepercayaan buruk pada produk yang dijual. Sebagaimana sabda Rasulullah:

"Yang dinamakan berjualan dengan sumpah palsu adalah usaha untuk melariskan barang dagangannya, lagi berusaha dengan cara yang tercela”.(HR Buchari dan Muslim).

Etika dalam melakukan promosi juga diperhatikan oleh Rasulullah, Beliau mengingangatkan para penjual tentang pentingnya cara dalam melakukan penjualan melalui hadist berikut: Rasulullah bersabda “ Duduklah! Sesungguhnya 
kamu menawarkan dengan duduk itu lebih mudah mendatangkan rezeki." (HR Thusi). Hal tersebut terjadi karena pada saat itu Rasulullah melewati seorang pedagang yang sedang menawarkan produknya, orang tersebut tinggi sedang baju yang ditawarkan pendek.

Dampak yang akan timbul dari promosi yang berlebihan adalah kekecewaan yang dirasakan oleh konsumen karena produk yang diperoleh tidak sesuai dengan ekspektasi, sehingga mengakibatkan konsumen tersebut memberikan informasi negatif kepada calon pembeli yang lain melalui media word of mouth. Ketidak jujuran dalam proses promosi merupakan prilaku yang sangat dilarang karena dapat merusak keuntungan yang diperoleh, baik itu financial, relasional, kepercayaan dan keberlangsungan bisnis dalam jangka panjang. Menurut pandangan islam bahwa dalam proses promosi tidak dibenarkan melakukan penipuan baik dalam bentuk prilaku maupun perkataan, bahkan seorang salesman atau customer relation tidak etis apabila memberikan pujian yang berlebihan atas produk yang ditawarkan kepada konsumen.

Etika dalam berbisnis dijelaskan pula dalam firman Allah Swt pada QS. Az-Zukhruf 43:19.

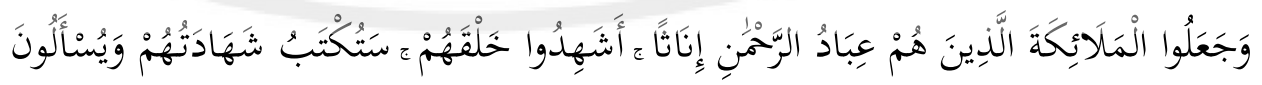

"Dan mereka menjadikan malaikat-malaikat yang mereka itu adalah hamba-hamba Allah Yang Maha Pemurah sebagai orang-orang perempuan. Apakah mereka menyaksikan penciptaan malaika-malaikat 
itu? Kelak akan dituliskan persaksian mereka dan mereka akan dimintai pertanggung-jawaban. ”(Q.S Az-Zukhruf:19)

Kemudian dalam proses penerapan bauran promosi juga termasuk pada perbuatan-berpuatan yang dijelaskan dalam firman Allah, diantaranya:

1. Periklanan

Pada proses peruiklanan akan menimbulkan efek penasaran bagi para penerima informasi, sehingga bagi penerima informasi tersebut diharuskan melakukan pengecekan dari apa yang diterima untuk menghindari adanya kesalahan.

Sebagaimana firman Allah dalam al-Quran Surah al-huujurat ayat 6 yang berbunyi:

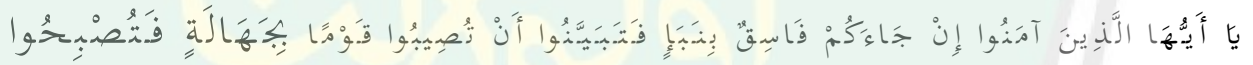

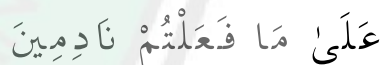

Artinya:Hai orang-orang yang beriman, jika datang kepadamu orang fasik membawa suatu berita, maka periksalah dengan teliti agar kamu tidak menimpakan suatu musibah kepada suatu kaum tanpa mengetahui keadaannya yang menyebabkan kamu menyesal atas perbuatanmu itu.(Q.S Al-Hujurat:6)

Maka, untuk menghindari kesalahan maka kita sebagai manusia ketika menerima informasi dari siapapun harus dilakukan pengecekan terlebih dahuu 
untuk mengetahui kebenarannya. Dan dalam proses periklanan maka dapat mendorong seseorang untuk melakukan kunjungan pada perusahaan tersebut untuk mengetahui tentang kebenaran dari perusahaan tersebut.

\section{Penjualan Pribadi}

Dalam berdagang diperlukan sikap yang baik antara penjual kepada pembeli, karyawan toko tunggal tata bersikap ramah dalam melayani pembeli merupakan suatu sikap yang benar. Dijelaskan dalam firman Allah pada al-Quran surah Ali-Imran ayat 159 sebagai berikut:

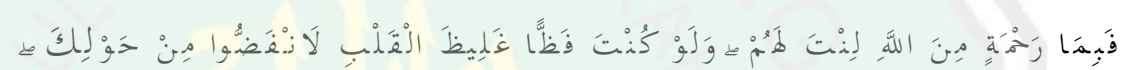

Artinya: Maka disebabkan rahmat dari Allah-lah kamu berlaku lemah lembut terhadap mereka. Sekiranya kamu bersikap keras lagi berhati kasar, tentulah mereka menjauhkan diri dari sekelilingmu.(Q.S Ali-Imran:

Maka, sebaik-baiknya seseorang dalam melayani pembeli adalah dengan bersikap lemah lembut karena pembeli adalah raja .

\section{Promosi Penjualan}

Dalam islam, selama hadiah yang diberikan tidak mempengaruhi harga dan bertujuan untuk memenuhi taget beli maka hal itu diperbolehkan sebagai bentuk hukum asal dari muamalah, yaitu halal. Muamalah dilakukan atas dasar suka sama suka. 
Sebagaimana firman Allah dalam surah An-Nsia ayat 29:

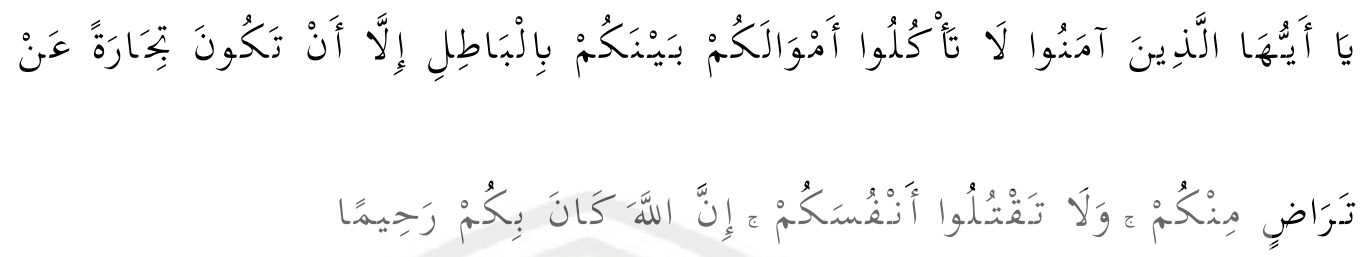

Artinya: Hai orang-orang yang beriman, janganlah kamu saling memakan harta sesamamu dengan jalan yang batil, kecuali dengan jalan perniagaan yang berlaku dengan suka sama-suka di antara kamu. Dan janganlah kaтu membunuh dirimu; sesungguhnya Allah adalah Maha Penyayang kepadamu.(Q.S An-Nisa:29)

\subsubsection{Volume Penjualan}

Menurut Rangkut (2009:57) bahwa penjualan merupakan pertukaran hak milik atas jasa atau barang uyang dilakukan oleh penjualan kepada pembeli dengan harga yang telah disepakati bersama dengan jumlah yang dibebankan penjual kepada pembeli dalam satu periode akuntansi. Dapat pula disebut dengan pemindahan hak milik atas barang atau jasa dengan imbalan uang sebagai gantinya sesuai dengan persetujuan yang disepakati. Menurut Ismaya (2007:253) bahwa volume penjualan merupakan hasil dari dagangan yang diperoleh atau ingin diperoleh suatu perusahaan dalam jangka waktu tertentu. 
2.3 Kerangka Berfikir

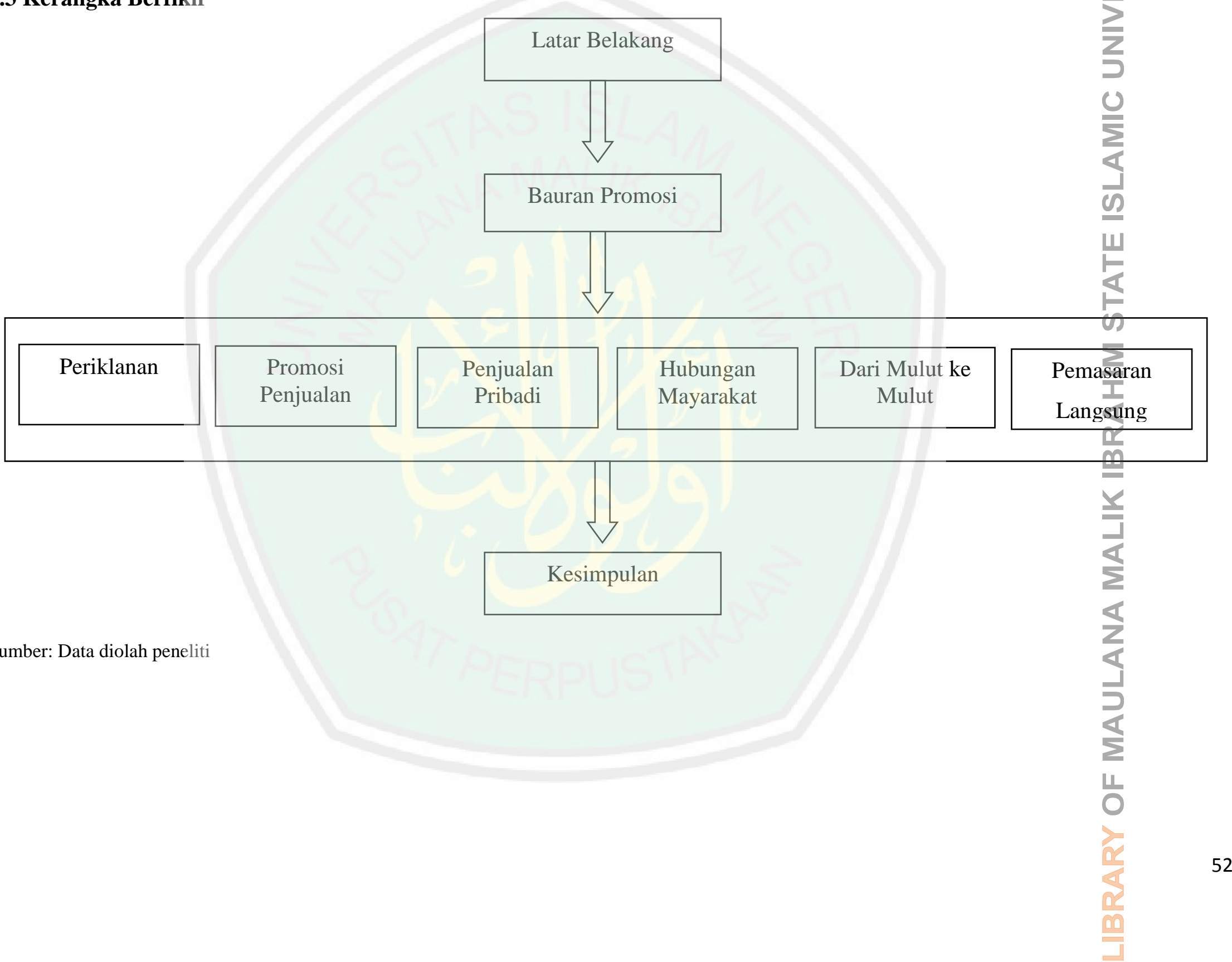




\section{BAB III \\ METODE PENELITIAN}

\subsection{Lokasi Penelitian}

Penulis melakukan penelitian pada lokasi yang merupakan tempat dari adanya permasalahan mengenai bauran promosi dalam meningkatkan volume penjualan, sehingga diharapkan dapat menangkap keadaan dari objek yang diteliti dalam rangka memperoleh data. Maka dalam penelitian ini, penulis memilih lokasi pada toko material bangunan Tunggal Tata yang masih menggunakan sistem penjualan secara manual. Toko material bangunan Tunggal Tata bertempat di desa sembungrejo kecamatan merakurak, kabupaten Tuban.

\subsection{Jenis dan PendekatanPenelitian}

Jenis penelitian ini menggunakan metode penelitian kualitatif dengan pendekatan deskriptif implementasi bauran promosi pada toko material bangunan Tunggal Tata, dimana penelitian dilakukan sesuai kondisi lapangan dengan mengumpulkan data dan mempelajari dokumen-dokumen yang diperoleh. Metode kualitatif ini dilakukan pada kondisi lapangan dari obyek yang diteliti. Sebagaimana penelitian kualitatif menurut Creswell (2015:59) bahwa penelitian tersebut dimulai dengan penggunaan kerangka teoritis dan asumsi yang membentuk atau memengaruhi studi tentang permasalahan riset yang terkait dengan makna yang dikenakan oleh individu atau kelompok pada fenomena 
sosial. Sehingga penelitian ini dilakukan atas dasar pengungkapan adanya penggunaan teori pada fenomena yang terjadi pada peningkatan volume penjualan toko tunggal tata.

Pendekatan dari penelitian ini adalah dengan metode deskriptif karena ingin mengetahui bagaimana toko Tunggal Tata dapat meningkatkan volume penjualan melalui implementasi bauran promosi. Gulo (2000:19) memaparkan bahwa penelitian deskriptif berarti ingin mengetahui bagaimana suatu peristiwa itu terjadi secara lebih luas dan terperinci karena peneliti tidak hanya meneliti masalahnya melainkan juga variabel lain yang berhubungan dengan permasalahan yang sedang diteliti. Berdasarkan ungkaapan diatas, maka penelitian deskriptif menggambarkan bahwa seluruh data yang diperoleh pada saat penelitian berlangsung merupakan kunci dari proses penelitian.

Penelitian ini menggunakan jenis penelitian strudi kasus sehingga dapat mendalami fenomena yang terjadi saat ini dari objek yang diteliti secara menyeluruh. Sebagaimana menurut Yiin (2014:1) bahwa studi kasus merupakan strategi yang paling cocok pada suatu penelitian yang berkenaan dengan kata bagaimana dan mengapa, bila peneliti hanya memiliki sedikit peluang untuk mengontrol peristiwa yang akan di selidiki, dan penelitian yang terfokus pada fenomena kontemporer di dalam konteks kehidupan nyata. 


\subsection{Subyek Penelitian}

Menurut Sarantokos dalam Poerwondari (2005:37) bahwa prosedur penelitian subjek dan sumber data pada penelitian dengan metode kualitatif menampilkan beberapa karakterisktik, diantaranya:

1. Diarahkan pada kasus-kasus tipikal yang sesuai dengan kehususan dari fenomena yang diteliti.

2. Tidak ditentukan secara kaku, tetapi dapat berubah karakteristik sampel dan jumlahnya sesuai dengan pemahaman konseptual yang berkembang dalam penelitian.

3. Tidak diarahkan pada keterwakilan, melainkan pada kecocokan konteks penelitian.

Sementara untuk memenuhi keperluan pengambilan data maka subyek dari penelitian ini adalah pemilik toko, karyawan, dan konsumen.

\subsection{Sumber Data}

Penelitian ini mengambil data melalui sumber data primer dan data sekunder.

1. Data Primer menurut Purhantara (2010:79) merupakan data yang diperoleh dari subjek penelitian secara langsung, dan peneliti memperoleh data-data atau informasi dengan menggunakan instrumen yang telah ditetapkan. Sebagaimana yang paparkan oleh Indriantono \& Supomo dalam Purhantara 
(2010:79) bahwa data primer berisikan tentang opini subjek, hasil observasi dari suatu kejadian dan hasil dari pengujian. Dalam penelitian ini, sumber data primer diperoleh secara langsung melalui wawancara dan observasi. Wawancara dilakukan kepada pihak memahami dan berkaitan langsung dengan penjualan di toko material bangunan Tunggal tata, sedangkan observasi juga dilaksanakan di lapangan yakni tempat proses penjualan toko material bangunan tunggal tata.

2. Data sekunder menurut Purhantara (2010:79) merupakan data yang diperoleh secara tidak langsung dari objek yang diteliti yang bersifat publik diantaranya yaitu: kearsipan, struktur organisasi, dokumen, buku-buku dan laporanlaporan. Pada penelitian ini data sekunder yang diperoleh yaitu berupa dokumen dokumen hasil penjualan, dan katalog.

\subsection{Teknik Pengumpulan data}

Penyusunan pendapat-pendapat yang logis dapat menjadi fakta nyata dan teruji kebenaranya maka perlu dilakukannya analisis data melalui teknik pengumpulan data sebagai berikut

\section{Wawancara}

Menurut Purhantara (2010:80), wawancara adalah proses percakapan dengan maksud untuk mengontruksi mengenai orang, motivasi, kejadian, dan kegiatan, serta perasaan sebagaimana yang dilakukan dua pihak yaitu pewawancaraan dengan mengajukan pertanyaan kepada lawan bicara. Sebagaimana ungkapan 
tersebut maka metode wawancara yang dilakukan peneliti adalah melalui proses berhadapan langsung dengan narasumber yakni terdiri dari pemilik toko, karyawan, dan konsumen. Dengan demikian maka peneliti dapat memperoleh data secara lebih jelas sehingga mampu menjelaskan permasalahan yang akan dibahas pada penelitian.

\section{Observasi}

Proses observasi ini merupakan pengamatan dan penyelidikan secara lansung terhadap fenomena-fenomena yang terjadi pada toko material tunggal tata, kemudian dilakukan pencatatan. Sebagaimana yang di paparkan oleh Usman \& Akbar (2006:54) bahwa observasi merupakan pengamatan dan pencatatan terhadap gejala-gejala yang diteliti secara sistematis.

\section{Dokumentasi}

Peneliti melakukan dokumentasi berupa foto aktivitas yang dilakukan di toko tunggal tata yang berkaitan penting dalam memberikan bukti pada hasil penelitian, kemudian peneliti meminta data penjualan, dan nama-nama pelanggan.

\subsection{Analisis Data}

Data yang telah di peroleh dari objek peneliti akan di analisis melalui metode-metode yang dapat menjelaskan hasil dari penelitian secara jelas. Sebagaimana yang diungkapkan juga oleh salim (2006:22) bahwa proses analisis data dengan metode kualitatif dapat berlangsung selama dan pasca pengumpulan data. 


\subsubsection{Tahap Analisis Data}

Menurut Salim (2006:20) tahap analisis data dapat menggunakan teknik Interactive Model sebagai berikut:

1. Reduksi data

Data yang diperoleh sangat banyak sehingga peneliti melakukan reduksi data, yaitu dengan merangkum data yang diperoleh kemudian memfokuskan pada data yang diperlukan dalam penyajian penelitian.

2. Penyajian data

Peneliti melakukan penyajian dari data yang telah dipilah tersebut dalam bentuk tabel, grafik, dan naskah yang mudah dipaham.

3. Kesimpulan atau verifikasi

Setelah dilakukan pengumpulan, reduksi, dan penyajian data maka diperlukan adanya penarikan kesimpulan dari hasil penelitian tersebut, kemudian dilakukan verifikasi yang diperoleh dari data-data yang didapatkan peneliti. Apabila kesimpulan tersebut valid berdasarkan bukti-bukti yang diperoleh dari lapangan, maka kesimpulan yang dikemukakan oleh peneliti merupakan kesimpulan yang kredibel.

\subsubsection{Kredibilitas Data}

Pada penelitian kualitatif, kredibilitas data mengacu pada temuan penelitian terhadap situasi dan didukung oleh bukti. Menurut Usman \& Purnomo (2009:98) bahwa kredibilitas merupakan keseuaian antara konsep yang dimiliki 
penulis dengan konsep responden. Sehingga untuk memeriksa dan menetapkan kevalidan pada penelitian ini maka teknik yang digunakan adalah metode triagulasi, penggunaan alat bantu pengumpulan data, dan menggunakan member check.

1. Triagulasi

Patton, dalam sutopo (2006:93) mengemukakan bahwa konsep triagulasi terdiri dari empat jenis, diantaranya:

a. Triagulasi data: teknik ini bisa disebut dengan teknik sumber yaitu dengan digunakannya berbagai macam sumber data dan situasi yang berbeda. Variasi sumber data yang digunakan pada penelitian ini adalah hasil wawancara dan hasil observasi dengan beberapa orang yang memiliki aktivitas sama, pada waktu yang relatif berbeda, dan tempat pengumpulan data yang berbeda.

b. Triagulasi peneliti: yaitu dengan digunakannya beberapa penulis dan evaluator. Pada penelitian ini, dosen pembimbing ikut serta dalam memberikan masukan terhadap hasil pengumpulan data melalui sebuah pengamatan (expert judgment)

c. Triagulai teori: yaitu dengan digunakannya berbagai prespektif teori yang berbeda untuk menginterpretasikan data yang sama. Teori yang digunakann untuk menguji terkumpulnya data penelitian ini telah dijelaskan pada bab II.

d. Triagulasi metodologis: yaitu digunakannya metode yang berbeda dalam meneliti hal yang sama. Dalam hal ini peneliti melakukan 
wawancara, observasi, dan dokumentasi segingga dapat dilakukan perbandingan.

\section{Penggunaan alat bantu dalam mengumpulkan data}

Dalam proses pengumpulan data, peneliti menggunakan perekam suara sebagai alat bantu penulis pada proses wawancara sehingga memudahkan penulis dalam melakukan proses penyalinan informasi dalam bentuk naskah.

\section{Penggunaan Member Check}

Pemeriksaan ulang pada informasi yang diperoleh merupakan bagian terpenting.

Dalam hal ini peneliti memberikan pertanyaan ulang kepada orang yang telah di wawancara untuk dimintai pendapat tentang data yang telah terkumpul. 


\section{BAB IV}

\section{PAPARAN DAN PEMBAHASAN HASIL PENELITIAN}

\subsection{Paparan Data Hasil Penelitian}

Pemaparan metoe penelitian yang digunakan pada penelitian ini sudah dijelaskan dalam bab III yaitu data primer berupa data hasil wawancara dan observasi, dan menggunakan data skunder berupa dokumen-dokumen milik toko bangunan tunggal tata yang mendukung hasil wawancara dan observasi.

\subsubsection{Sejarah Singkat Toko Bangunan Tunggal Tata}

Toko tunggal tata didirikan oleh bapak H. Royom pada tahun 1999 dengan menyediakan kayu, selama berlangsungnya usaha ini jumlah permintaan semakin menurun sehingga mengakibatkan toko tunggal tata mengalami gulung tikar dengandengan kerugian dalam jumlah besar. Namun, karena kegigihan dari bapak H. Royom maka pada 2001 membuka memulai usaha baru pada bidang obat-obat pertanian dan BBM, kemudian ketika melihat peluang usaha pada bidang material bangunan maka pada tahun 2003 toko tunggal tata menyediakan material bangunan tetapi hanya satu jenis produk yaitu batu kapur. Jumlah karyawan yang bekerja di toko bangunan pada saat itu hanya 2 orang dan armada yang digunakan dalam proses pengiriman barang masih menggunakan sewa transportasi.

Seiring berjalannya waktu dan dengan pengelolaan penjualan yang baik, toko bangunan tunggal tata semakin berkembang pesat di tahun 2009 dengan produk matrial yang dijual bermacam-macam diantaranya yaitu batu kapur, bata 
ringan, pasir, semen, paving, perlengkapan kamar mandi (shower, kran, bathop, dll), bahkan toko tunggal tata telah memiliki 6 armada sebagai alat pengiriman barang, dan memiliki 18 karyawan. Hal tersebut membuktikan bahwa toko tunggal tata mengalami perkembangan pesat dengan jumlah permintaan yang semakin meningkat.

\subsubsection{Visi dan Misi}

Visi:

Membuka cabang toko bangunan Tunggal Tata di berbagai daerah

Misi:

1. Meningkatkan volume penjualan

2. Mengatasi pesaing

3. Mempersiapkan modal

\subsubsection{Struktur Organisasi}

Pada sebuah organisasi, maka perlu adanya kerjasama sehingga dapat mencapai tujuan yang telah ditetapkan. Dalam proses kerjasama antar individu diperlukan struktur organisasi agar tanggung jawab dan pembagian tugas dari masing-masing individu perjalan dengan lancar.

Sebagaimana pada umumnya, toko bangunan tunggal tata memiliki struktur organisasi yang terdiri dari pemilik toko dan karyawan, karyawan terbagi menjadi 2 kategori yakni yang bertugas di toko dan karyawan bagian pengiriman 
barang. Namun, struktur organisasi di toko banguna tungal tata tidak pernah dipaparkan secara tertulis karena pada awal merekrut karyawan langsung di briefing terkait tugasnya di toko bangunan tunggal tata.

\section{Gambar 4.1}

Struktur Organisasi Toko Bangunan Tunggal Tata

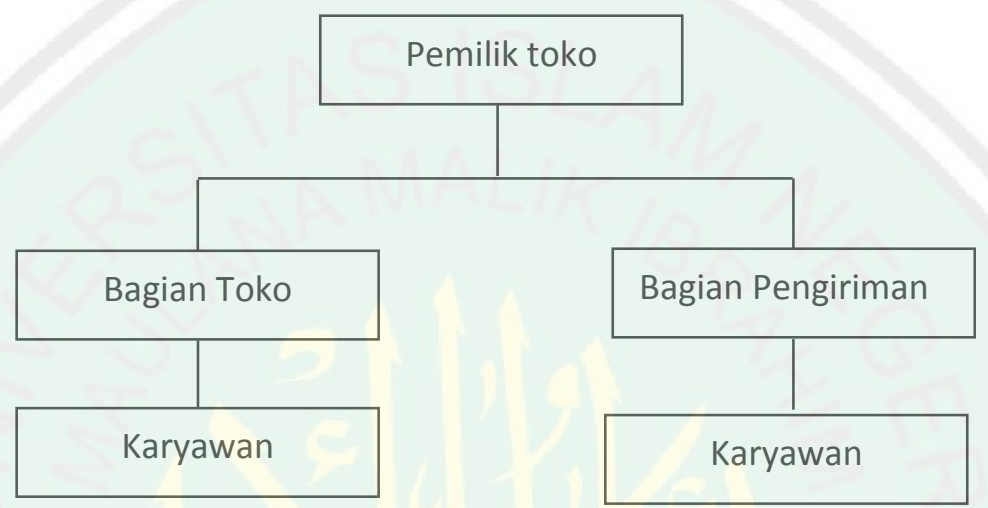

Sumber: Data diolah peneliti

a. Pemilik toko

Bapak H. Royom sebagai pemilik toko yang berperan sebagai pemantau dan penanggung jawab aktivitas kerja di toko tunggal tata, serta mengatur pembagian pengiriman barang ke konsumen

b. Bagian toko

Bagian di dalam toko terdiri dari 5 orang, yakni mbak hani, mbak wasrik, mbak ana, mbak kasniti, dan mbak siti. Para karyawan tersebut bertugas untuk melayani konsumen yang membeli dan memesan produk, serta bertanggung jawab untuk menjaga kondisi toko bangunan tunggal tata.

c. Bagian pengiriman

Pada bidang ini, para mengirim barang terdiri dari 6 driver dan 7 pengangkut. Dari totol seluruh karyawan pengiriman barang tersebut 
bekerjasama dalam pengankutan, pengecekan barang yang di angkut, dan sampainya barang di tempat konsumen.

\subsubsection{Lokasi Toko Bangunan Tunggal Tata}

Alamat: Jl. Merakurak, Semampir, Sembungrejo, Merakurak, Kabupaten Tuban

Gambar 4.2

Lokasi Toko bangunan Tunggal Tata
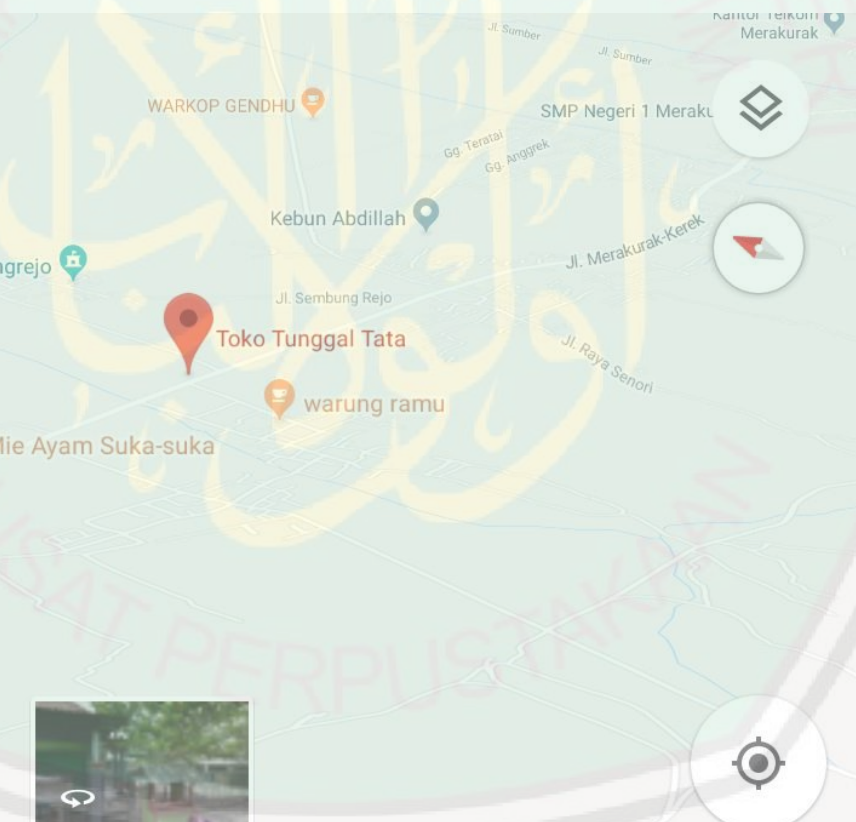

Sumber: Google Maps "Toko Tunggal Tata"

Pemilihan lokasi pada toko tunggal tata sangat strategis, karena di sebelah jalan raya yang hanya satu jalur untuk menuju ke pabrik semen indonesia, dan 
jalur ke berbagai instansi pendidikan di antara 2 kecamatan yakni kerek dan merakurak. Kemudian area parkir sangat luas.

\subsubsection{Logo}

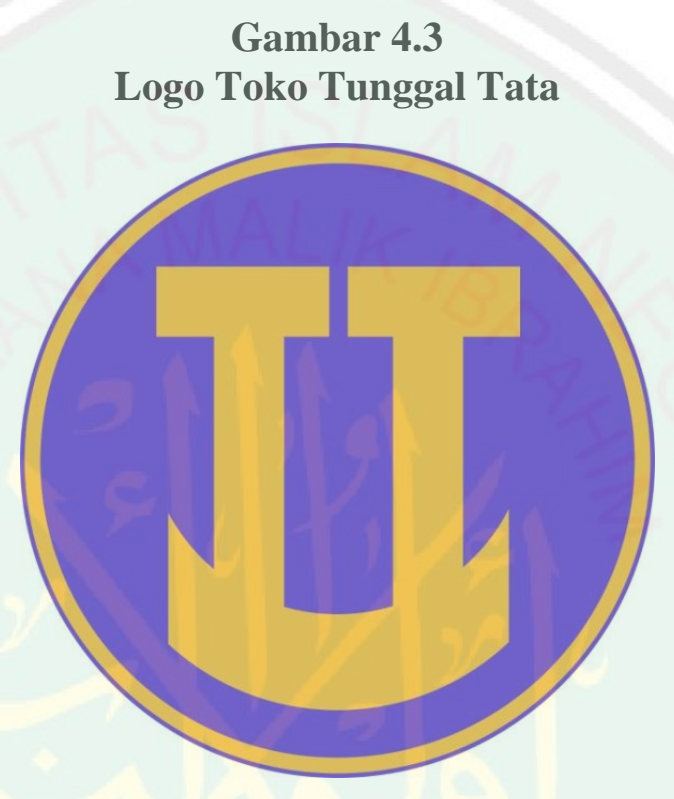

Sumber: Pemilik toko Tunggal Tata

Logo terdiri atas lambang logo. Logo pada lambang tersebut adalah 2 huruf balok "T" yang digabung dengan garis melengkung, makna dari logo ini memiliki unsur spiritual, bahwa lambang tersebut maksudnya adalah "Tunggal Tata" dan arti dari "Tunggal Tata" adalah hanya 1 yang menata dan mengatur semua di semsta yaitu Allah, hal itu diperkuat dengan ada garis lingkaran yang mengelilingi “Tunggal Tata” yaitu penguasa alam semseta. 


\subsection{Hasil Pembahasan Implementasi Bauran Promosi pada Toko Bangunan}

\section{Tunggal Tata}

Bauran promosi merupakan elemen dari bauran pemasaran yang memiliki keunggulan tersendiri dengan berbagai elemen didalamnya yang telah dipaparkan berdasarkan teori-teori pada bab II, yakni periklanan, promosi penjualan, penjualan pribadi, hubungan masyarakat, dari mulut ke mulut, dan pemasaran langsung. Berbagai elemen promosi tersebut masing-masing memiliki alat yang digunakan dalam proses promosi, hal itu diuraikan pula pada teori-teori di bab II. Dewasa ini, dengan adanya banyak pesaing maka lebih dari 1 elemen promosi sangat dibutuhkan agar bisnis berjalan dengan lancar dan sukses.

Sebagaimana yang dilakukan oleh Toko Bangunan Tunggal Tata yang menggunakan lebih dari 1 media promosi agar dapat berkembang dan menghadapi pesaing. Pemaparan dari hasil wawancara dan dokumentasi serta observasi yang telah dilakukan peneliti. Bahwa toko bangunan tunggal tata menggunakan beberapa elemen dari bauran promosi, diantaranya adalah periklanan, penjualan pribadi, promosi penjualan, pemasaran langsung, dan promosi dari mulut ke mulut. Berdasarkan pencarian data dilapangan, bahwa toko tunggal tata melakukan tindakan cukup baik dalam menghadapi besaing melalui penggunaan berbagai elemen bauran promosi tersebut.

Bertambahnya jumlah peminat/pembeli bahan bangunan untuk membangun infrastruktur dan untuk memperbaiki rumah dengan berbagai desain modern maka semakin banyak bermunculan toko dalam bidang toko bangunan 
yang menjual berbagai alat dan bahan bangunan, diantaranya dari bahan pokok yakni batu-bata, semen, pasir, kayu, genteng, hingga bahan tambahan yakni kramik, berbagai macam cat, dan alat-alat yang digunakan dalam proses pembangunan. Fenomena ini mengakibatkan tingkat persaingan semakin ketat. Hal itu menjadikan pemilik toko bangunan tunggal tata yakni bapak H.Royom semakin waspada dalam menjalankan bisnis bahan bangunan, dan meningkatkan berbagai strategi untuk mengatasi pesaing.

Secara tidak disadari, toko tunggal tata berhasil unggul dalam persaingan dengan menggunakan strategi SWOT dalam mengidentifikasi faktor-faktor secara exsternal maupun internal dengan teknik yang dikemukakan oleh Albert Humphrey pada tahun 1960-an. Dewasa ini dikemukakan oleh Bapak H. Royom pada tanggal 1 mei 2019 bahwa awal memulai bisnis dalam bidang bangunan material atas dasar kekuatan yang dimiliki yaitu memiliki tempat strategis yang kemudian memanfaatkan peluang bahwa banyak konsumen yang mencari material bangunan, sedangkan kelemahannya adalah pada modal awal sehingga toko tunggal tata melakukan pinjaman pada instansi perbankan. Namun pada saat ini banyak bermunculan toko material bangunan yang menjadi ancaman baru bagi toko tunggal tata sehingga toko bangunan tunggal menggunakan kekuatan untuk melakukan pemantauan harga yang ditawarkan pesaing kepada konsumen, dan yang paling utama adalah memantau strategi promosi yang digunakan oleh pesaing dalam menarik minat pelanggan sehingga pihak toko tunggal tata dapat memberikan penawaran harga terbaik untuk konsumen. Dengan berbagai kekuatan yang dimiliki, toko tunggal tata menciptakan ancaman baru bagi pesaing 
yaitu melayani konsumen dengan cepat dan tepat melalui 6 armada dalam proses pengiriman banrang, hal tersebut berhasil menjadi ancaman bagi pesaing toko tunggal tata.

Selain mengatasi ancaman dari luar toko tunggal tata melakukan perbaikan sistem penjualan didalamnya, usaha yang dilakuakan yaitu menata toko dengan baik. Berdasarkan pengamatan peneliti bahwa exsterior dan interior dari toko pesaing cenderung menimbulkan rasa ketidaknyamanan sehingga muncul ketidak puasan. Toko bangunan tunggal tata melakukan perbaikan dari sisi exsterior dan interior toko sehingga konsumen dapat mudah memperhatikan produk yang disediakan oleh toko tunggal tata melalui layou-tnya, dan memunculkan keinginan konsumen untuk melakukan pembelian ulang dengan suasana toko yang nyaman.

Tidak hanya menarik pelanggan untuk melakukan pembelian ulang, penjual juga perlu melakukan strategi agar jumlah pembeli semakin meningkat. Hal tersebut dapat dilakukan dengan menerapkan berbagai elemen dari bauran promosi, sebagaimana yang dijelaskan oleh Madura (2007:273) bahwa bauran promosi merupakan metode yang dapat digunakan oleh penjualan agar permintaan produk-produknya dapat meningkat. Sehingga dalam hal ini peneliti fokus pada bagaimana toko tunggal tata menghadapi pesaing dari dalam dengan implementasi bauran promosi yang digunakan.

Hal tersebut disampaikan dalam wawancara dengan informan, yakni pemilik toko bangunan Tunggal Tata, karyawan, dan konsumen, sebagaimana hasil paparan berikut ini: 


\subsubsection{Periklanan}

Komunikasi yang dilakukan secara tidak langsung untuk menumbuhkan rasa penasaran sehingga tumbuh keinginan konsumen untuk melakukan pembelian, hal demikian disebut dengan periklanan. Informasi yang disampaikan dalam komunikasi tidak langsung tersebut dapat dilakukan dengan berbagai media. Berikut hasil wawancara yang dilakukan oleh peneliti kepada pikah toko Tunggal Tata yakni 7 informan:

1. Peneliti bertanya pada tanggal 1 mei 2019 kepada pemilik toko Tunggal Tata: Bagaimana menurut bapak selaku pemilik toko Tunggal Tata terkait promosi periklanan yang diterapkan di toko Tunggal Tata?

Informan (bapak H. Royom) menjawab:

"Tidak pernah, ya memangnya kami sebagai yang punya toko. Sponsor itu sekarang ini hanya sekedar kaos dan saya tulisi toko saya, kemudian selain itu ya lewat orang-orang itu ya temen-temen itu, jadi sementara ini ya ndak pake sponsor lain istilahnya”

2. Peneliti bertanya pada tanggal 2 mei 2019 kepada karyawan toko Tunggal Tata:

Bagaimana menurut mbak Hani selaku karyawan toko Tunggal Tata terkait promosi periklanan yang diterapkan di toko Tunggal Tata?

Informan (mbak Hani) menjawab:

“Untuk promosi lewat sosial media atau sponsor-sponsor seperti itu tidak pernah" 
3. Peneliti bertanya pada tanggal 3 mei 2019 kepada konsumen dari toko Tunggal Tata:

Bagaimana menurut bapak selaku pelanggan di toko Tunggal Tata terkait promosi periklanan yang diterapkan oleh pihak toko Tunggal Tata?

Informan (bapak Dul Mukti) menjawab:

"Tidak ada mbak kalau iklan-iklan seperti di televisi itu"

4. Peneliti bertanya pada tanggal 3 mei 2019 kepada konsumen dari toko Tunggal Tata:

Bagaimana menurut bapak selaku pelanggan di toko Tunggal Tata terkait promosi periklanan yang diterapkan oleh pihak toko Tunggal Tata?

Informan (bapak Aryo) menjawab:

"kan banyak dari brosur kaos-kaos yang ada tulisannya toko ini kan, kalau untuk sosial media belum pernah melihat sih"

5. Peneliti bertanya pada tanggal 3 mei 2019 kepada konsumen dari toko Tunggal Tata:

Bagaimana menurut bapak selaku pelanggan di toko Tunggal Tata terkait promosi periklanan yang diterapkan oleh pihak toko Tunggal Tata?

Informan (bapak Puji Mulyo) menjawab:

"Sosial media, belum pernah" 
6. Peneliti bertanya pada tanggal 3 mei 2019 kepada konsumen dari toko Tunggal Tata:

Bagaimana menurut bapak selaku pelanggan di toko Tunggal Tata terkait promosi periklanan yang diterapkan oleh pihak toko Tunggal Tata?

Informan (bapak Anto) menjawab:

"nggak pernah, nggak pernah" (melihat dari brosur/sosial media)

7. Peneliti bertanya pada tanggal 3 mei 2019 kepada konsumen dari toko Tunggal Tata:

Bagaimana menurut bapak selaku pelanggan di toko Tunggal Tata terkait promosi periklanan yang diterapkan oleh pihak toko Tunggal Tata? Informan (bapak Sarmadi) menjawab:

"ya kalau tentang iklan saya tidak pernah melihat"

Berdasarkan hasil wawancara yang dilakukan peneliti kepada informan adalah bahwa dari pihak internal yakni pemilik toko Tunggal Tata meyakini bahwa kaos-kaos yang diberikan kepada para pelanggan merupakan salah satu bentuk sponsor. Sebagaimana yang disampaikan pula oleh konsumen yakni bapak Aryo bahwa beliau mengetahui tentang toko Tunggal Tata dari kaos-kaos berlogo Tunggal Tata yang pakai oleh masyarakat.

Namun pernyataan tersebut berbeda dengan yang disampaikan oleh karyawan bahwa tidak pernah ada iklan ataupun sponsor tentang toko Tunggal Tata. Kemudian hal itu diperkuat dari pernyataan yang disampaikan oleh 4 konsumen yakni bapak Dul Mukti, bapak Puji Mulyo, bapak Anto, dan bapak 
Sarmadi bahwa tidak pernah ada promosi yang disampaikan oleh toko Tunggal Tata melalui media iklan seperti sosial media.

Berdasarkan observasi yang telah dilakukan oleh peneliti pada tanggal 1-3 mei 2019, dapat diketahui bahwa ada beberapa tumpukan kaos bertuliskan toko tunggal tata yang disediakan oleh pihak tunggal tata, kemudian diberikan kepada pembeli sebagai hadiah pembelian. Selama 3 hari melakukan pengamatan, peneliti memantau bahwa ada 7 konsumen yang datang di toko tunggal tata telah berpakaian kaos bertuliskan "toko tunggal tata".

Maka, secara tidak langsung bahwa kaos yang diberikan oleh toko Tunggal Tata kepada para konsumen merupakan media promosi yang digunakan dalam penerapan promosi periklanan. Berdasarkan penjelasan yang disampaikan oleh pemilik toko Tunggal Tata dan pernyataan dari salah satu konsumen maka dapat disimpulkan bahwa kaos yang diberikan oleh pihak toko tunggal tata kepada para konsumen memiliki peran penting untuk menarik pelanggan baru. Hal tersebut terjadi karena banyak konsumen yang memiliki kaos bertuliskan "Toko Tunggal Tata" sehingga memunculkan rasa penasaran kepada masyarakat yang belum pernah melakukan pembelian di toko tunggal tata.

Melalui pemakaian/penggunaan kaos bertuliskan "toko tunggal tata" oleh pelanggan diberbagai tempat mengakibatkan tumbuhnya rasa penasaran konsumen lain tentang keberadaan toko tunggal tata sehingga menyebabkan para konsumen melakukan kunjungan di toko tunggal tata dan melakukan pembelian. Dari bertambahnya jumlah konsumen melalui alat tersebut dapat disebutkan 
bahwa toko tunggal tata mengimplementasikan bauran promosi pada elemen periklanan.

Hal diatas merupakan implementasi periklanan yang dilakukan oleh toko tunggal tata yang telah sesuai dengan teori yang disampaikan oleh tjiptono (1997:222) bahwa untuk mengubah pikiran seseorang agar melakukan pembelian maka dapat dilakukan dengan memberikan informasi kepada konsumen tentang keunggulan produk melalui berbagai alat diantaranya, iklan cetak, film, brosur, poster, selebaran, direktori, billboard, bahan audiovisual, logo atau simbul, dan lain-lain.

Bahkan dalam islam dijelaskan bahwa ketika seseorang mendapatkan informasi dari seseorang lainnya maka seseorang itu harus memeriksa informasi yang diperoleh secara teliti agar tidak terjadi adanya kesalahan. Sebagaimana firman Allah dalam al-Quran Surah al-huujurat ayat 6 yang berbunyi:

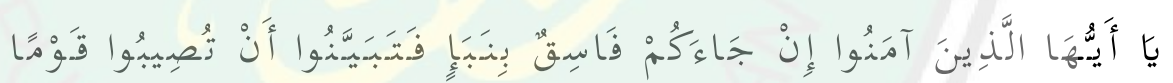

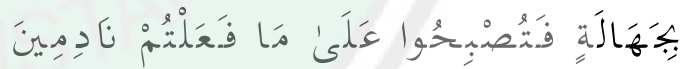

Artinya:Hai orang-orang yang beriman, jika datang kepadamu orang fasik membawa suatu berita, maka periksalah dengan teliti agar kamu tidak menimpakan suatu musibah kepada suatu kaum tanpa mengetahui keadaannya yang menyebabkan kamu menyesal atas perbuatanmu itu.(Q.S Al-Hujurat:6) 
Ayat diatas memerintahkan manusia untuk meneliti atau melakukan pengecekan terhadap informasi yang diperoleh. Dalam hal ini melalui kaos berlogo "toko tunggal tata" yang digunakan oleh konsumen toko tersebut menimbulkan rasa penasaran kepada konsumen lain sehingga konsumen lain mengunjungi toko bangunan tunggal tata dan pada momen tersebut karyawan toko tunggal tata melayani konsumen baru dengan menerapkan elemen promosi penjualan pribadi.

\subsubsection{Penjualan Pribadi}

Pertemuan antara penjual dan pembeli untuk memperkenalkan produk yang ditawarkan tanpa adanya perantara, komunikasi tersebut merupakan salah satu elemen dari promosi penjualan pribadi.promosi tersebut dilakukan oleh berbagai kegiatan bisnis, salah satunya pada usaha toko tunggal tata. Berikut hasil wawancara yang dilakukan peneliti kepada 7 informan toko Tunggal Tata:

1. Peneliti bertanya pada tanggal 1 mei 2019 kepada pemilik toko Tunggal Tata: Bagaimana penerapan penjualan pribadi/proses pelayanan yang dilakukan oleh karyawan kepada pembeli?

Informan (bapak H. Royom) menjawab:

"Ya itu penting sekali (pelayanan) dan perlu karena pelayanannya itu saya tekankan kepada anak buah saya itu harus bagaimana ya, pokoknya harus kalau disini tuh namanya sumeh, setiap ada orang pembeli tuh harus cepat-cepat ditanggapi gitu, kalo ada yang datang seakan-akan itu belum masuk di ruangan penjual itu sudah di song-song gitu lo, ditanggapi gitu 
lo, ya mungkin itu termasuk promosi juga, terus anak buah saya itu saya tekankan jangan terlalu keras, maksunya itu harus lemahlembut, ramah"

2. Peneliti bertanya pada tanggal 2 mei 2019 kepada Karyawan toko Tunggal Tata :

Bagaimana penerapan penjualan pribadi melalui komunikasi yang dilakukan karyawan kepada para pembeli?

Informan (Mbak Hani) menjawab:

"ya misal kalau pembeli itu datang terus saya layani mau cari apa"

3. Peneliti bertanya pada tanggal 3 mei 2019 kepada Konsumen toko Tunggal Tata :

Bagaimana penerapan penjualan pribadi melalui pelayanan yang dilakukan oleh karyawan kepada anda?

Informan (bapak Dul Mukti) menjawab:

"untuk pelayanan di toko Tunggal Tata ini saya rasa sangat bagus sekali, ramah dan tamah, sering senyum mbak"

4. Peneliti bertanya pada tanggal 3 mei 2019 kepada Konsumen toko Tunggal Tata :

Bagaimana penerapan penjualan pribadi melalui pelayanan yang dilakukan oleh karyawan kepada anda?

Informan (bapak Aryo) menjawab: 
"Pelayanannya juga bagus, pokoknya cocoknya disini”"

5. Peneliti bertanya pada tanggal 3 mei 2019 kepada Konsumen toko Tunggal

Tata :

Bagaimana penerapan penjualan pribadi melalui pelayanan yang dilakukan oleh karyawan kepada anda?

Informan (bapak Puji Mulyo) menjawab:

"lumayan bagus (pelayanan), cepat"

6. Peneliti bertanya pada tanggal 3 mei 2019 kepada Konsumen toko Tunggal Tata :

Bagaimana penerapan penjualan pribadi melalui pelayanan yang dilakukan oleh karyawan kepada anda?

Informan (bapak Anto) menjawab:

"di sini pelayanannya tepat, cepat"

7. Peneliti bertanya pada tanggal 3 mei 2019 kepada Konsumen toko Tunggal Tata :

Bagaimana penerapan penjualan pribadi melalui pelayanan yang dilakukan oleh karyawan kepada anda?

Informan (bapak Sarmadi) menjawab:

"disini toko ini pelayanannya ramah, terus bosnya juga supel orangnya" 
Berdasarkan hasil wawancara yang dilakukan peneliti kepada informan adalah bahwa dari pihak internal yakni pemilik toko Tunggal Tata meyakini bahwa karyawanmelakukan pelayanan dengan baik dan menjalin hubungan baik melalui sikap ramah pada saat berinteraksi dengan pembeli. Penjelasan tersebut diperkuat oleh pernyataan yang disampaikan oleh karyawannya bahwa dalam melakukan interaksi secara tatap muka dengan para pembeli maka melakukan suatu komunikasi. Komunikasi tersebut merupakan salah satu pemanfaatan fungsi dari promosi penjualan pripadi.

Kemudian pernyataan dari 5 informan yakni konsumen yang merupakan pihak eksternal dari toko Tunggal Tata tersebut berkesinambungan dengan pernyataan dari pemilik dan karyawan toko Tunggal Tata bahwa para konsumen merasakan pelayanan yang bagus sehingga hal itu merupakan alat komunikasi tatap muka yang digunakan oleh pemilik dan karyawan toko tunggal tata dalam mengimplementasikan promosi penjualan pribadi.

Bahkan berlandaskan dari observasi yang dilakukan oleh peneliti dari tanggal 1-3 mei 2019 di toko bangunan tunggal tata, dapat dinyatakan bahwa pelayanan yang diberikan oleh karyawan kepada konsumen sangat ramah dan cepat tanggap. Pemilik toko juga sangat supel kepada konsumen, bahkan terkadang timbul obrolan diluar pembahasan produk yang sedang dibeli.

Toko Tunggal Tata melakukan penerapan elemen promosi penjualan pribadi untuk menjadi penguat penerapan pormosi periklanan. Dalam hal ini berdasarkan hasil wawancara dan observasi yang dilakukan oleh peneliti bahwa karyawan telah melakukan penerapan promosi penjualan pribadi dengan 
melakukan pelayanan yang baik kepada konsumen sehingga mereka memutuskan untuk melakukan pembelian. Tindakan yang dilakukan oleh karyawan tersebut sesuai degan teori yang dikemukakan oleh madura (2007:274) bahwa penjualan pribadi merupakan presentasi yang dilakukan secara perorangan untuk memberikan pengaruh bagi pembeli, dan pada penjualan ritel promosi ini tidak menjadi tantangan karena satiap konsumen datang memiliki tujuan untuk melakuka pembelian.

Dalam berdagang diperlukan sikap yang baik antara penjual kepada pembeli, karyawan toko tunggal tata bersikap ramah dalam melayani pembeli merupakan suatu sikap yang benar. Dijelaskan dalam firman Allah pada al-Quran surah Ali-Imran ayat 159 sebagai berikut:

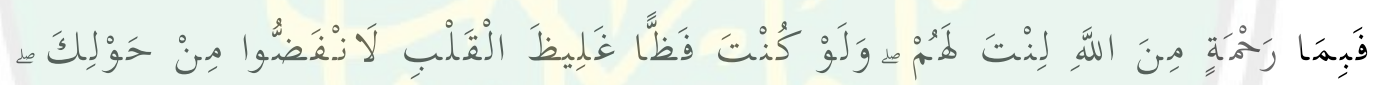

Artinya: Maka disebabkan rahmat dari Allah-lah kamu berlaku lemah lembut terhadap mereka. Sekiranya kamu bersikap keras lagi berhati kasar, tentulah mereka menjauhkan diri dari sekelilingmu.(Q.S AliImran:159)

Penjualan Pribadi sangat diperlukan karena memiliki berbagai fungsi berdasarkan penjelasan dari Tjiptono (1997:222) bahwa promosi penjualan pribadi dapat mendukung elemen promosi yang lain dengan berbagai fugsi yaitu Prospecting (mencari pembeli kemudian menjalin hubungan baik dengan mereka), Targeting (penjual mengalokasikan waktu yang tepat demi kenyamanan 
konsumen), Comunicating (penjual selalu memberikan informasi tentang produk yang dijual kepada konsumen), Selling (penjual melakukan pendekatan, mendemonstrasi, dan mengatasi penolakan dari konsumen), Servicing (pelayanan dan jasa diberikan oleh penjual agar konsumen merasa puas), Informating Gathering (melakukan riset pasar), Allocating (penentuan pelanggan).

Melalui ungkapan teori tersebut dan berdasarkan penelitian yang telah dilakukan oleh peneliti maka toko tunggal tata telah menerapkan beberapa fungsi dari promosi penjualan pribadi diantaranya, karyawan bersikap ramah dan menjalin hubungan baik dengan pembeli yang datang, dan memberikan informasi tentang produk yang dijual dengan pelayanan jasa yang baik sehingga pembeli merasa puas. Penerapan fungsi yang dilakukan oleh karyawan toko tunggal tata tersebut mampu mendukung penerapan elemen dari promosi penjualan. 


\subsubsection{Promosi Penjualan}

Promosi penjualan dilakukan dengan memberikan insentif pada pelanggan sehingga menambah kesan daya tarik kepada mereka terhadap produk yang dijual. toko tunggal tata juga melakukan promosi penjualan dengan mengaplikasikan berbagai media. Sebagaimana hasil wawancara yang dilakukan oleh peneliti kepada para informan sebagai berikut:

1. Peneliti bertanya pada tanggal 1 mei 2019 kepada pemilik toko Tunggal Tata: Bagaimana penerapan promosi penjualan yang dilakukan toko tunggal tata/bagaimana cara pemilik toko Tunggal Tata dalam mendorong konsumen untuk lebih tertarik dengan toko Tunggal Tata?

Informan (bapak H. Royom) menjawab:

"yang ada itu kadang-kadang membeli suatu barang contoh ya ini seumpama beli baut akhirnya di bawa pulang dan ternyata nggak cocok, nah saya pesan (pak kalau ini ndak cocok ya di kembalikan tapi dengan syarat tidak rusak). Kalau diskon atau hadiah itu endak, tapi kalau seumpama nominal Rp.40-jutaan atauRp. 30-jutaan itu biasanya ya diberi kenang-kenangan diberi kompor seharga Rp. 400rb atau kipas angin seharga Rp. 200rb. Nah ini yang penting lagi saya kan di desa, didesa itu kan ada banyak orang teman-teman atau tetangga-tenagga itu kalau berhubungan sosial itu ya itu juga saya pake, bukan cuma hadiah-hadiah itu saja. Itu kalau di desa itu terpenting kalau di kota memangnya ndak ada itu kalau promonya besar-besaran kemudian orang kenal, kalau di kota kan itu tau toko ini-toko ini, kalau di desa kan enggak" 
2. Peneliti bertanya pada tanggal 2 mei 2019 kepada karyawan toko Tunggal Tata:

Bagaimana proses penerapan promosi penjualan yang dilakukan toko tunggal tata/bagaimana cara anda sebagai karyawan dalam mendorong konsumen untuk lebih tertarik dengan toko Tunggal Tata?

Informan (mbak Hani) menjawab:

"kalau belinya banyuak sih biasanya dikasih hadiah"

3. Peneliti bertanya pada tanggal 3 mei 2019 kepada konsumen toko Tunggal Tata:

Promosi penjualan seperti apa yang diberikan oleh toko Tunggal Tata sehingga anda sebagai konsumen tertarik dengan toko Tunggal Tata?

Informan (bapak Dul Mukti) menjawab:

"Barang yang saya pesen langsung dianter"

4. Peneliti bertanya pada tanggal 3 mei 2019 kepada konsumen toko Tunggal Tata:

Promosi penjualan seperti apa yang diberikan oleh toko Tunggal Tata sehingga anda sebagai konsumen tertarik dengan toko Tunggal Tata?

Informan (bapak Aryo) menjawab:

"Kalau kita beli volumenya agak banyak kan dianter sampai tempat”

5. Peneliti bertanya pada tanggal 3 mei 2019 kepada konsumen toko Tunggal Tata: 
Promosi penjualan seperti apa yang diberikan oleh toko Tunggal Tata sehingga anda sebagai konsumen tertarik dengan toko Tunggal Tata?

Informan (bapak Puji Mulyo) menjawab:

“apa ya, ya mungkin karena barangnya lengkap”

6. Peneliti bertanya pada tanggal 3 mei 2019 kepada konsumen toko Tunggal Tata:

Promosi penjualan seperti apa yang diberikan oleh toko Tunggal Tata sehingga anda sebagai konsumen tertarik dengan toko Tunggal Tata?

Informan (bapak Anto) menjawab:

"Kalau diskon sih nggak pernah"

7. Peneliti bertanya pada tanggal 3 mei 2019 kepada konsumen toko Tunggal Tata:

Promosi penjualan seperti apa yang diberikan oleh toko Tunggal Tata sehingga anda sebagai konsumen tertarik dengan toko Tunggal Tata?

Informan (bapak Sarmadi) menjawab:

"Kita kalau sering di toko Tunggal Tata ini, biasanya kalau istilahnya ya kita ngambil barang barang, kita bisa bayar lunas maka dapat Fee, istilahnya ya diberi kipas angin, entah jaket gitu mbak"

Berdasarkan hasil wawancara yang dilakukan peneliti kepada informan adalah bahwa dari pihak internal yakni pemilik toko Tunggal Tata menyatakan bahwa konsumen yang membeli barang dengan nominal Rp. 40jutaan atau Rp. 30jutaan akan diberikan kenang-kenangan sebagai bentuk penghargaan kepada 
para pelanggan, serta didukung pernyataan dari karyawan bahwa apabila konsumen membeli barang dalam jumlah tertentu maka diberi hadiah. Hadiah yang diberikan merupakan berbagai cara untuk mendorong pelanggan menambah jumlah barang yang dibeli.

Konsumen juga memberi pernyataan yang berkesinambungan dengan pemilik dan karyawan toko Tunggal Tata bahwa toko tunggal tata memberikan kenag-kenangan (hadiah) yang disesuaikan dengan jumlah pembelian barang . Hal itu dapat mendorong pelanggan untuk melakukan pembelian dengan jumlah volume yang lebih banyak. Toko tunggal tata memberikan hadiah sebagai reward kepada konsumen yang melakukan pembayaran lunas dari pembelian bahan bagunan dengan pembelian senilai 30-40jutaan.

Namun, walaupun terdapat 4 informan eksternal yang tidak sejalan dengan pernyataan yang disampaikan oleh pihak toko Tunggal tata tetapi peneliti memiliki bukti dari hasil observasi pada tanggal 1-3 Mei 2019 bahwa dapat diketahui ada beberapa tumpukan kaos bertuliskan toko tunggal tata yang disediakan oleh pihak tunggal tata untuk diberikan kepada pembeli sebagai hadiah pembelian. Ada pula kompor yang diberikan kepada pembeli yang telah membayar lunas barang yang telah dibeli.

Metode yang dilakukan oleh pihak toko Tunggal Tata merupakan alat dari yang digunakan untuk meningkatkan jumlah pembelian dari para pelanggan. penerapan promosi penjualan tersebut sesuai dengan teori yang dikemukakan oleh Simamora (2000:756) yang mengungkapkan bahwa promosi penjualan dapat menjadi salah satu alat insentif yang dominan digunakan dalam jangka waktu 
pendek untuk memancing konsumen melakukan pembelian secara cepat dan dalam jumlah banyak. Hal itu dirasakan oleh pihak toko tunggal tata bahwa dengan menargetkan satu konsumen dengan jumlah pembelian tertentu maka konsumen tersebut diberi insentif berupa hadiah.

Dalam islam, selama hadiah yang diberikan tidak mempengaruhi harga dan bertujuan untuk memenuhi taget beli maka hal itu diperbolehkan sebagai bentuk hukum asal dari muamalah, yaitu halal. Muamalah dilakukan atas dasar suka sama suka sebagaimana firman Allah dalam surah An-Nsia ayat 29:

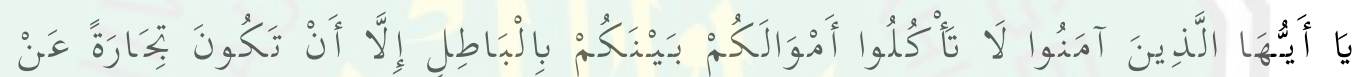

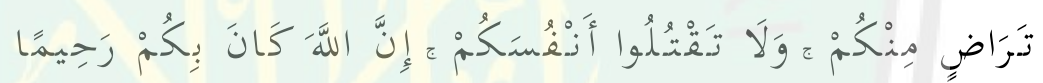

Artinya: Hai orang-orang yang beriman, janganlah kamu saling memakan harta sesamamu dengan jalan yang batil, kecuali dengan jalan perniagaan yang berlaku dengan suka sama-suka di antara kamu. Dan janganlah kaтu membunuh dirimu; sesungguhnya Allah adalah Maha Penyayang kepadamu.(Q.S An-Nisa:29)

Menurut tjiptono (1997:222) bahwa ada berbagai macam alat yang dapat digunakan dalam proses promosi penjualan, diantaranya: undian, hadiah, produk sampel, pameran dagang, tawaran pengembalian uang,diskon, jaminan produk, dan lain-lain. Selain memberuikan insentif berupa hadiah yang berikan kepada konsumen, toko tunggal tata memberikan tawara pengembalian uang jika terjadi 
kekeliruan dalam melakukan penjualan produk namun dengan catatan harus ada perjanjian terlebih dahulu. Selain promosi penjualan sebagai bentuk memotivasi konsumen untuk melakukan pembelian, toko tunggal tata menerapkan elemen promosi untuk menghemat waktu dalam proses penjualan/pelayanan terhadap konsumen dengan menggunakan pemasaran langsung.

\subsubsection{Pemasaran Langsung}

Bentuk komunikasi yang dilakukan penjual secara langsung kepada konsumen dapat dilakukan dengan berbagai media diantaranya melalui telepon dan berbagai katalog dan lain-lain, hal itu merupakan promosi yang dilakukan pada elemen pemasaran langsung. Sebagaimana yang dilakukan oleh toko tunggal tata agar menghemat waktu dalam proses perbelanjaan, dalam hasil wawancara kepada informan bahwa dibenarkan adanya media katalog yang digunakan dalam proses promosi, berikut hasil wawancara yang dilakukan oleh peneliti:

1. Peneliti bertanya pada tanggal 1 mei 2019 kepada pemilik toko Tunggal Tata: Bagaimana penerapan bauran promosi yang dilakukan toko Tunggal tata dalam memasarkan produk secara langsung? Apa mungkin melalui katalog, pesan email, ataupun telepon?

Informan (bapak H.Royom) menjawab:

"Iya, ya ada katalog warna cat"

2. Peneliti bertanya pada tanggal 2 mei 2019 kepada karyawan toko Tunggal Tata: 
Bagaimana penerapan bauran promosi yang anda lakukan dalam memasarkan produk secara langsung kepada konsumen? Apa mungkin melalui katalog, pesan email, ataupun telepon?

Informan (mbak Hani) menjawab:

"orang kalau cari cat saya beri katalog original, tapi semisal tidak cocok ya saya kasih cat oplosan yang warnanya lebih bagus, nanti saya oplos sendiri"

3. Peneliti bertanya pada tanggal 3 mei 2019 kepada konsumen toko Tunggal Tata:

Bagaimana penerapan promosi yang dilakukan toko Tunggal Tata kepada anda dalam memasarkan produk secara langsung? Apa mungkin melalui media katalog, pesan email, ataupun telepon?

Informan (bapak Dul Mukti) menjawab:

"Ada mbak, ini juga saya beli cat milih dari katalog”

4. Peneliti bertanya pada tanggal 3 mei 2019 kepada konsumen toko Tunggal Tata:

Bagaimana penerapan promosi yang dilakukan toko Tunggal Tata kepada anda dalam memasarkan produk secara langsung? Apa mungkin melalui media katalog, pesan email, ataupun telepon?

Informan (bapak Aryo) menjawab:

"pelayanannya melalui katalog memang ada, biasanya saya memilih warna dari katalo yang duisediakan dengan berbagai merek" 
5. Peneliti bertanya pada tanggal 3 mei 2019 kepada konsumen toko Tunggal

Tata:

Bagaimana penerapan promosi yang dilakukan toko Tunggal Tata kepada anda dalam memasarkan produk secara langsung? Apa mungkin melalui media katalog, pesan email, ataupun telepon?

Informan (bapak Puji Mulyo) menjawab:

"tidak pernah sih ada promosi masuk dari telepon, tapi untuk katalog biasanya ada untuk warna cat, jadi kalau milih bisa enak"

6. Peneliti bertanya pada tanggal 3 mei 2019 kepada konsumen toko Tunggal Tata:

Bagaimana penerapan promosi yang dilakukan toko Tunggal Tata kepada anda dalam memasarkan produk secara langsung? Apa mungkin melalui media katalog, pesan email, ataupun telepon?

Informan (bapak Anto) menjawab:

"untuk saat ini saya belum pernah membeli barang yang ada katalognya, dan tidak pernah menerima promosi dari telepon"

7. Peneliti bertanya pada tanggal 3 mei 2019 kepada konsumen toko Tunggal Tata:

Bagaimana penerapan promosi yang dilakukan toko Tunggal Tata kepada anda dalam memasarkan produk secara langsung? Apa mungkin melalui media katalog, pesan email, ataupun telepon? 
Informan (bapak Sarmadi) menjawab:

"ya mbak, saya biasanya membeli cat ya milihnya dari kataloh itu, dan warnanya aada macam-macam"

Berdasarkan hasil wawancara yang dilakukan peneliti kepada informan adalah bahwa dari pihak internal yakni pemilik toko Tunggal Tata memberikan pernyataan yang memiliki makna bahwa toko tunggal tata menawarkan warna cat menggunakan katalog berbagai macam warna baik itu original maupun campuran sehingga pempermudah proses perbelanjaan. Hal tersebut diungkapkan pula oleh karyawan dan konsumen pahwa dalam membeli produk cat maka menggunakan katalog untuk memilih warna.

Hal tersebut sejalan dengan hasil observasi yang dilakukan peneliti pada saat mengamati keadaan yang ada di toko tunggal tata, dan terlihat ada berbagai katalog cat dengan berbagai merek cat yang disediakan di dalam toko untuk memudahkan konsumen dalam memilih warna sesuai dengan kebutuhan konsumen. Dan katalog tersebut merupakan salah satu alat yang dapat digunakan sebagai promosi pada elemen pemasaran langsung.

Sebagaimana yang disampaikan oleh tjiptono (1997:222) bahwa dalam melakukan promosi pemasaran langsung, maka alat yang digunakan dapat bermanfaat untuk menghemat waktu perbelanjaan dan dapat bersifat rahasia, salah satu alat nya adalah katalog. Maka pemasaran langsung telah dilakukan oleh pihak toko tunggal tata melalui alat katalog sehingga proses perbelanjaan konsumen di 
tunggal tata akan berjalan secara mudah, cepat dan tepat sehingga tidak muncul rasa bosan dari konsumen, dan konsuemn akan merasa nyaman.

\subsubsection{Dari Mulut Ke Mulut}

Promosi yang sangat mempengaruhi penjualan yaitu komunikasi yang dilakukan antar masyarakat yang secara tidak langsung mempromosikan produk penjual dengan menceritakan pengalaman pembelian yang dirasakan. Sehingga dalam hal ini peneliti melakukan wawancara hanya dengan pihak eksternal toko Tunggal Tata yakni 5 informan (konsumen) sebagai berikut:

1. Peneliti bertanya pada tanggal 3 mei 2019 kepada konsumen toko Tunggal Tata:

Darimanakah anda mendapatkan informasi terkait toko Tunggal Tata Informan (bapak Dul Mukti) menjawab:

"Saya mengenal toko ini dari inisiatif sendiri (berkunjung di toko Tunggal Tata), memang dulunya toko ini sangat kecil ternyata lama-lama toko ini kok menjadi besar"

2. Peneliti bertanya pada tanggal 3 mei 2019 kepada konsumen toko Tunggal Tata:

Darimanakah anda mendapatkan informasi terkait toko Tunggal Tata Informan (bapak Aryo) menjawab: 
“mendapatkan informasi tentang toko ini pertama dari temen yang cerita, pernah juga ada temen yang sempat tanya (tentang toko ini) juga saya kasih tau”

3. Peneliti bertanya pada tanggal 3 mei 2019 kepada konsumen toko Tunggal Tata:

Darimanakah anda mendapatkan informasi terkait toko Tunggal Tata Informan (bapak Puji Mulyo) menjawab:

"tau tentang toko ini pertama kali dari temeb, dari temen-temen kerja"

4. Peneliti bertanya pada tanggal 3 mei 2019 kepada konsumen toko Tunggal Tata:

Darimanakah anda mendapatkan informasi terkait toko Tunggal Tata Informan (bapak Anto) menjawab:

"Dari temen (mengetahui informasi tentang toko ini) desa Temandang"

5. Peneliti bertanya pada tanggal 3 mei 2019 kepada konsumen toko Tunggal Tata:

Darimanakah anda mendapatkan informasi terkait toko Tunggal Tata Informan (bapak Sarmadi) menjawab:

"teman-teman mbak, banyak yang bilang kalau toko Tunggal Tata itu lengkap"

Beberapa pernyataan konsumen tentang toko tunggal tata tersebut bahwa para konsumen mengetahui keberadaan toko tunggal tata dan tertarik untuk 
membeli di toko tunggal tata melalui informasi yang diberikan oleh pelanggan lain. Mereka membicarakan pengalaman pembelian yang didapatkan dari toko tunggal tata kepada konsumen lain sehingga konsumen yang lain tertarik dan mencoba melakukan pembelian pula di toko tunggal tata.

Namun, 1 konsumen menyatakan bahwa mengetahui tentang toko ini dengan sendirinya. Tetapi pernyataan konsumen tersebut lebih dominan mengetahui informasi terkait toko Tunggal Tata atas informasi yang disampaikan oleh teman-teman mereka yang merupakan pelanggan dari toko Tunggal Tata. Maka proses komunikasi yang terjadi antar konsumen tersebut termasuk dalam promosi dari mulut ke mulut karena dari komunikasi tersebut berhasil memicu adanya pembelian dari konsumen baru.

Maka, dari berbagai elemen promosi yang telah berhasil diterapkan oleh toko tunggal tata yakni periklanan, penjualan pribadi, promosi penjualan, dan pemasaran langsung, semua elemen tersebut mampu memberikan penilaian positif bagi konsumen sehingga dalam wawancara yang dilakukan peneliti dengan konsumen menunjukkan bahwa timbul rasa puas dari konsumen sehingga mereka memberikan informasi terkait toko tunggal tata kepada konsumen lain, hal itu membuat konsumen lain tertarik untuk mencoba melakukan pembelian di toko tunggal tata. Bahkan dari hasil wawancara peneliti dengan konsumen, masingmasing dari mereka mengetahui informasi terkait toko tunggal tata adalah didapatkan dari cerita teman sehingga melakukan pembelian bahan bangunan di toko tunggal tata. Hal ini sesuai dengan teori promosi yang timbul dari komunikasi antar masyaratkat. 
Teori yang mendukung aktivitas yang dilakukan para konsumen tersebut yaitu menurut Lupiyoadi (2001:108) bahwa promosi dari mulut kemulut sangat memberi pengaruh pada pemasaran karena peran konsumen dalam mempromosikan jasa penjualan melalui pembicaraannya kepada konsumen lain terkait pengalaman dalam melakukan menerima jasa pelayanan. Bahkan menurut Hasan (2010:33) bahwa pengalaman yang diberikan konsumen terhadap konsumen lain merupakan suatu pujian dan rekomendasi agar konsumen melakukan pembelian. Manfaat dari promosi mulut ke mulut sagatlah beharga karena memiliki nilai kejujuran dari seorang teman kepada teman lainnya dalam memperoleh pengalaman pembelian, kemudian memberi manfaat lebih bagi teman yang bertanya. Hal itu dirasakan oleh konsumen toko tunggal tata sehingga mampu tertari dengan toko tunggal tata melalui informasi yang diberikan oleh seorang teman yang jujur dan sangat meyakinkan sebagai influencer.

Bahkan dalam Islam dijelaskan terkait pengaruh teman bagi seseorang, sehingga ketika memiliki teman yang baik maka akan memberikan manfaat baik untuk diri tersebut namun jika berteman dengan orang yang jelek maka akan terjerumus kedalam lubang kemaksiatan. Hal itu disampaikan oleh Rasulullah Saw bahwa:

"Permisalan teman yang baik dan teman yang buruk ibarat seorang penjual minyak wangi dan seorang pandai besi . penjual minyak wangi mungkin akan memberimu minyak wangi, atau engkau bisa membeli minyuak wangi darinya, dan kalaupun tidak, engkau tetap mendapatkan bau harum dirinya. Sedangkan pandai besi, bisa jadi (percikan apinya) 
mengenai pakaianmu, dan kalaupun tidak engkau tetap mendapatkan bau asapnya yang tak sedap”. (HR.Bukhari 5534 dari Muslim 2628)

Hadist tersebut juga dapat memiliki arti bahwa jika memiliki teman yang baik ataupun buruk maka akan berdampak kepada teman yang lainnya. Sehingga dianjurkan untuk memilih teman yang baik. Dalam hal ini para konsumen menjadi pelanggan toko Tunggal Tata dari informasi yang diperoleh melalui pelanggan lainnya, maka pelanggan yang menjadi influencer tersebut memberikan pengaruh yang baik kepada teman yang lainnya, sebagaimana dalam hadist diatas.

\subsubsection{Temuan di Lapangan}

Selain melakukan 5 elemen dari bauran promosi diatas, toko bangunan tunggal tata menerapkan pelayanan tambahan diluar unsur bauran promosi, dari hasil wawancara yang dilakukan peneliti kepada 7 informan, masing-masing dari mereka memberi pernyataan yang merupakan temuan baru bagi peneliti. Berikut hasil wawancara:

1. Peneliti bertanya pada tanggal 3 mei 2019 kepada konsumen toko Tunggal Tata:

Apa perbedaan toko Tunggal Tata dengan toko bangunan yang lain?

Informan (bapak Dul Mukti) menjawab:

"Toko bangunan ini saya rasa perbedaannya sangat banyak sekali dengan toko yang lain mbak, terutama pembayaranya kalau kurang itu bisa istilahe ngutang lah, kalau di bangunan ini contohnya saya baru mau 
renovasi rumah ini untuk dana kurang ini bisa saya minta keringanan alias ngutang”

2. Peneliti bertanya pada tanggal 3 mei 2019 kepada konsumen toko Tunggal Tata:

Apa perbedaan toko Tunggal Tata dengan toko bangunan yang lain?

Informan (bapak Anto) menjawab:

"kalau beli disini bisa hutang, nggak pernah dikasih jatuh tempo tapi dari pihak kita sendiri setiap satu bulan sekali satu minggu sekali memberi uang”

3. Peneliti bertanya pada tanggal 3 mei 2019 kepada konsumen toko Tunggal Tata:

Apa perbedaan toko Tunggal Tata dengan toko bangunan yang lain?

Informan (bapak Sarmadi) menjawab:

"yang paling penting mbak bisa ngutang, kalau kita punya dana ada kurangnya, itu biasanya nitip, terus nanti kalau mbangun udah selesai itu biasanya ya dari toko Tunggal Tata tidak memberi jatuh tempo tetapi kita yang punya inisiatif sendiri (untuk membayar)"

4. Peneliti bertanya pada tanggal 1 mei 2019 kepada pemilik toko Tunggal Tata: Apa perbedaan toko Tunggal Tata dengan toko bangunan yang lain? Informan (bapak H.Royom) menjawab:

“Gini, kalau itu bukan melayani hutang, tapi cuma gini biasanya pembeli saya kan itu seorang pegawai, pegawai itu kan ndak tiap hari di rumah 
kemudian kan pembangunan itu kan kadang kurang ini kurang itu nah kadang-kadang oragnya itu titip uang ke saya kemudian tukangnya tingal minta barang ke saya gitu saja terus totalan itu belakang iutu yang maksudnya hutang. Kalau sudah selesai banguunan dikerjakang maka sibos tadi baru bayar ke saya."

Pernyataan itu diungkapkan oleh pemilik toko tunggal tata bahwa para pelanggan diberikan keringanan pada sitem pembayaran sebagai bentuk pelayanan tambahan kepada para pelanggan. kemudian berdasarkan pernyataan dari informan yang merupakan pelanggan toko Tunggal Tata tersebut bahwa mereka merasakan pelayanan lain diluar elemen pada bauran promosi. Beberapa infroman tersebut mengungkapkan ketertarikan pada toko Tunggal Tata adalah dengan pemberian keringanan dalam melakukan pembayaran. Keringan dalam pembayaran yang dimaksudkan dalam wawancara tersebut bahwa toko tunggal tata memberi keringanan kepada konsumen dalam proses pembayaran yaitu dalam bentuk hutang, hal itu dilakukan oleh pemilik sebagai bentuk pelayanan tambahan agar para konsumen yang membutuhkan barang namun memiliki kendala keuangan tetap bisa teratasi, dan untuk pembayaran diberi waktu pada saat musim panen tiba.

Pernyataan tersebut disampaikan pula oleh beberapa konsumen bahwa keunggulan dan perbedaan toko tunggal tata dengan toko lain adalah melayani sistem hutang dan pembayaran lunas dilakukan pada saat pembelian terakhir. Pelayanan sitem hutang tanpa ada jatuh tempo yang jelas tersebut tidak termasuk dalam elemen bauran promosi yang dikemukakan oleh para ahli. Sehingga cara 
tersebut merupakan penerapan pelayanan yang secara alamiah dilakukan oleh toko tunggal tata.

\subsection{Implikasi dari Implementasi Bauran Promosi pada Toko Bangunan} Tunggal Tata

Peneliti telah melakukan observasi dan wawancara yang disertai dengan bukti dokumentasi. Hal tersebut memunculkan berbagai cara yang dilakukan oleh toko tunggal tata dalam menerapkan bauran promosi. Dari berbagai elemenelemen promosi yang berhasil diterapkan oleh toko tunggal tata memiliki berbagai akibat dan bahkan mendapatkan konsekuensi dari hasil penerapan bauran bromosi tersebut. Toko tunggal tata menjalankan bisnis dalam bidang toko bangunan tersebut berangkat tanpa memiliki pengetahuan tentang teori promosi, namun cara yaang dilakukan oleh toko tunggal tata secara tidak langsung merupakan penerapan dari berbagai elemen promosi.

\subsubsection{Periklanan}

Elemen periklanan pada bauran promosi merupakan pokok yang tergolong sering digunakan oleh pebisnis modern melalui berbagai alat diantaraanya televisi, reklame, brosur dan lain sebagainya. Dengan berbagai media tersebut maka pesan dari iklan yang diberikan pelaku bisnis kepada konsumen akan tersampaikan dengan menghemat waktu dan biaya. Namun berbeda dengan toko tunggal tata, secara tidak langsung kaos-kaos yang diberikan oleh toko tunggal tata kepada para pelanggan dan kemudian dipakai/digunakan tersebut memberikan dampak 
positif, yaitu terjadi penyampaikan pesan kepada konsumen baru untuk mendorong mereka melakukan kunjungan di toko bangunan tunggal tata. Sebagaimana hasil wawancara yang dilakukan peneliti kepada beberapa informan sebagai berikut:

Pertanyaan kepada pihak internal:

1. Peneliti bertanya pada tanggal 1 mei 2019 kepada pemilik toko Tungal Tata: Apakah dampak yang diperoleh dengan adanya promosi periklanan?

Informan (bapak H.Royom) menjawab:

"ya lumayan (menambah pelanggan) tapi hanya beberapa persen saja karena toko saya kan di desa jadi mudah diketahui sama orang banyak, lain di kota kan banyak toko jadi yang ini jual ini kan agak sulit, kalo ini kan enggak, toko mudak diketahu orang banyak"

Pertanyaan kepada pihak eksteral:

2. Peneliti bertanya pada tanggal 3 mei 2019 kepada konsumen toko Tungal Tata:

Bagaimana efek dari adanya informasi melalui periklanan tersebut?

Informan (bapak Aryo) menjawab:

“dengan adanya gambar toko dimanaa-mana ya pastinya membuat saya tergugah untuk datang ke toko Tunggal Tata karena rasa penasaran ini"

Hal tersebut dapat terjadi karena dengan adanya logo bertuliskan "toko tunggal tata" di setiap kaos yang banyak dipakai/digunakan oleh pelanggan akan 
memunculkan rasa penasaran oleh konsumen lain terhadap toko tunggal tata sehingga mereka ingin merasakan pelayanan yang diperoleh dari toko tunggal tata. Berbagai perasaan dan keinginan untuk melakukan pembelian dari konsumen baru terhadap toko bangunan tunggal tata tersebut merupakan akibat yang diperoleh toko tunggal tata dari promosi yang talah disampaikan melalui media kaos tersebut dan perilaku tersebut merupakan dampak positif yang didapatkan dari penerapan elemen promosi periklanan.

\subsubsection{Penjualan Pribadi}

Sebagai akibat yang diperoleh dari penerapan promosi periklanan yakni bertambahnya jumlah konsumen baru, maka penerapan elemen promosi yang lain sangat perlu diterapkan. Dalam hal ini dengan memiliki banyak pelanggan maka toko tunggal tata memberikan pelayanan yang baik kepada konsumen dengan menciptakan rasa nyaman di benak konsumen dan menimbulkan dampak positif sebagaimana wawancara yang telah dilakukan peneliti kepada informan, sebagai berikut:

Pertanyaan kepada pihak internal:

1. Peneliti bertanya pada tanggal 1 mei 2019 kepada pemilik toko Tungal Tata:

Dengan adanya penerapan penjualan pribadi yang dilakukan karyawan kepada konsumen melalui proses pelayanan, apa akibat yang diperoleh?

Informan (bapak H.Royom) menjawab:

"iya menimbulkan dampak positif, kan nanti komunikasi bisa lancar dan konsumen merasa puas" 
2. Peneliti bertanya pada tanggal 2 mei 2019 kepada karyawan toko Tungal Tata:

Dengan adanya penerapan penjualan pribadi melalui pelayanan yang anda terapkan kepada konsumen, apa akibat yang diperoleh?

Informan (mbah Hani) menjawab:

"kalau saya pelayanannya bagus ya mereka yang beli pasti senang”

Pernyataan kepada pihak eksternal:

3. Peneliti bertanya pada tanggal 3 mei 2019 kepada konsumen toko Tungal Tata:

Melalui proses pelayanan yang dilakukan oleh karyawan apakah membuat konsuemen bertahan menjadi konsumen toko Tunggal Tata?

Informan (bapak Dul Mukti) menjawab:

"sehingga sudah lama mbak, sudah berapa tahun(penegasan)"

4. Peneliti bertanya pada tanggal 3 mei 2019 kepada konsumen toko Tungal Tata:

Melalui proses pelayanan yang dilakukan oleh karyawan apakah membuat konsuemen bertahan menjadi konsumen toko Tunggal Tata?

Informan (bapak Aryo) menjawab:

"Sayasudah bertahun-tahun langganan disini mbak" 
5. Peneliti bertanya pada tanggal 3 mei 2019 kepada konsumen toko Tungal Tata:

Melalui proses pelayanan yang dilakukan oleh karyawan apakah membuat konsuemen bertahan menjadi konsumen toko Tunggal Tata?

Informan (bapak Puji Mulyo) menjawab:

"sudah lama mbak, langganan disini sudah lama sekali"

6. Peneliti bertanya pada tanggal 3 mei 2019 kepada konsumen toko Tungal Tata:

Melalui proses pelayanan yang dilakukan oleh karyawan apakah membuat konsuemen bertahan menjadi konsumen toko Tunggal Tata?

Informan (bapak Anto) menjawab:

"Menjadi pelanggan disini sudah tiga tahun"

7. Peneliti bertanya pada tanggal 3 mei 2019 kepada konsumen toko Tungal Tata:

Melalui proses pelayanan yang dilakukan oleh karyawan apakah membuat konsuemen bertahan menjadi konsumen toko Tunggal Tata?

Informan (bapak Sarmadi) menjawab:

"Saya disini sudah lama mbak"

Dampak positif tersebut merupakan bentuk kesetiaan konsumen untuk menjadi pelanggan tetap di toko Tunggal Tata, hal tersbut diungkapkan pada hasil wawancara bahwa telah dirasakan oleh masing-masing konsumen yakni pelayanan yang diberikan oleh toko tunggal tata sangat bagus melalui komunikasi 
yang diciptakan oleh karyawan dengan konsumen. Dari kepuasan yang muncul dari pihak konsumen maka mengakibatkan mereka melakukan pembelian ulang di toko bangunan tunggal tata sehingga menjadi pelanggan toko tunggal tata dalam jangka waktu yang lama.

Berbagai hasil wawancara peneliti dengan para konsumen tersebut dapat disimpulkan bahwa mereka telah melakukan pembelian secara berulang di toko tunggal tata. Hal yang dilakukan tesebut merupakan dampak positif peroleh toko tunggal tata melalui penerapan proses promosi penjualan pribadi yang diperoleh pihak konsumen sehingga mereka merasa nyaman dan menjadi penaggan tetap di toko bangunan tunggal tata.

\subsubsection{Promosi penjualan}

Perlu adanya promosi penjualan yang dilakukan dalam berbagai bisnis. Dengan memiliki banyak pelanggan maka toko tunggal tata memberikan hadiah kepada para konsumen yang telah melakukan pembelian pada jumlah tertentu, hadiah tersebut berupa kaos berlogo "toko tunggal tata" dan barang-barang rumah tangga lainnya seperti kompor, kipas, dan lain sebagainya. Berikut hasil wawancara tentang implikasi toko Tunggal Tata dengan adanya penerapan promosi penjualan:

\section{Pertanyaan kepada pihak internal:}

1. Peneliti bertanya pada tanggal 1 mei 2019 kepada pemilik toko Tungal Tata: Melalui adanya penerapan promosi penjualan tersebut maka apa yang diperoleh pihak toko Tunggal Tata? 
Informan (bapak H.Royom) menjawab:

"kalau dikasih kenang-kenangan seperti itu ya para pelanggan

termotivasi untuk membeli barang dengan jumlah yang lebih banyak”

2. Peneliti bertanya pada tanggal 2 mei 2019 kepada konsumen toko Tungal Tata:

Melalui adanya penerapan promosi penjualan tersebut maka apa yang diperoleh pihak toko Tunggal Tata?

Informan (mbak Hani) menjawab:

"biasanya kalau ada hadiah jadinya orang-orang ngeborong barang biar dapet hadiah itu"

Petanyataan kepada pihak eksternal:

3. Peneliti bertanya pada tanggal 3 mei 2019 kepada karyawan toko Tungal Tata:

Apa yang dirasakan ketika mendapatkan insentif (bentuk penerapan dari promosi penjualan) dari toko tunggal tata?

Informan (bapak Dul Mukti) menjawab:

"kalau saya beli di sini itu barangnya langsung diantar mbak, jadi tidak menunggu lama”

4. Peneliti bertanya pada tanggal 3 mei 2019 kepada karyawan toko Tungal Tata:

Apa yang dirasakan ketika mendapatkan insentif (bentuk penerapan dari promosi penjualan) dari toko tunggal tata? 
Informan (bapak Aryo) menjawab:

"saya tetap bertahan disini, karena dibanding dengan toko lain malah biasanya barang tidak diantar kalau pesan sedikit”

5. Peneliti bertanya pada tanggal 3 mei 2019 kepada karyawan toko Tungal Tata:

Apa yang dirasakan ketika mendapatkan insentif (bentuk penerapan dari promosi penjualan) dari toko tunggal tata?

Informan (bapak Puji Mulyo) menjawab:

"karena barangnya lengkap jadi saya tidak perlu repot-repot ke toko lain"

6. Peneliti bertanya pada tanggal 3 mei 2019 kepada karyawan toko Tungal Tata:

Apa yang dirasakan ketika mendapatkan insentif (bentuk penerapan dari promosi penjualan) dari toko tunggal tata?

Informan (bapak Sarmadi) menjawab:

"dengan adanya pemberian Fee tadi ya membuat saya bertahan"

Berdasarkan hasil wawancara yang dilakukan peneliti dengan para informan membuktikan bahwa toko bangunan tunggal tata menerapkan promosi penjualan dengan media pemberian hadiah kepada para pelangggan dengan pembelian pada jumlah tertentu, hadiah tersebut merupakan reward yang diberikan toko tunggal tata untuk memotivasi para pelanggan untuk terus melakuka pembelian. Melalui penerapan tersebut maka berakibat positif bagi 
pihak toko tunggal tata yakni semakin bertambahnya jumlah pembelian yang dilakukan oleh konsumen sehingga volume penjualan toko Tunggal Tata mengalami peningkatan.

Tabel 4.1

Data Penjualan Toko Tunggal Tata Tahun 2015-2018

\begin{tabular}{|c|c|c|}
\hline Tahun & Penjualan & \multicolumn{1}{|c|}{$\begin{array}{c}\text { Presentase } \\
\text { Kenaikan }\end{array}$} \\
\hline 2015 & Rp. 7.099.250.000 & $19,5 \%$ \\
\hline 2016 & Rp. 8.484.900.000 & \\
& Rp. 10.639.750.000 & $25,4 \%$ \\
\hline 2017 & Rp. 13.519.600.000 & \\
\hline Total & Rp. 39.013.500.000 & \\
\hline Rata-rata & Rp. 9.753.375.000 & \\
\hline
\end{tabular}

Sumber: Data Toko Tunggal Tata 2019

Berdasarkan data yang diperoleh peneliti dari toko Tunggal Tata bahwa selama 4 tahun terakhir volume penjualan toko Tunggal Tata mengalami peningkatan secara signifikan, selisih antara tahun 2015 dengan tahun 2016 senilai Rp 1.385.650.000, kemudian kenaikan terjadi lagi pada tahun 2017 senilai Rp 2.154.850.000, hingga kenaikan yang lebih tinggi pada tahun 2018 senilai Rp 2.879.850.000. Data tersebut membuktikan bahwa penjualan pada toko Tunggal Tata telah naik, hal itu terjadi akibat implementasi promosi penjualan yang dijalankan oleh toko Tunggal Tata. 


\subsubsection{Pemasaran Langsung}

Pemasaran langsung merupakan kegiatan promosi yang dilakukan agar dalam proses penjualan berjalan secara efektif sehingga pada toko tunggal tata juga menerapkan promosi pemasaran langsung. Dengan banyaknya peelanggan yang dimiliki toko bangunan tunggal tata dan volume pembelian yang dilakukan oleh konsumen selalu meningkat maka disamping pelayanan yang ramah dan bagus maka proses pelayanan harus dilakukan secara efektif untuk menghindari kekecewaan yang muncul di benak konsumen. Berikut wawancara yan dilakukan dengan informan terkait dampak yang dirasakan dari penerapan elemen pemasaran langsung:

Pertanyaan kepada pihak internal:

1. Peneliti bertanya pada tanggal 1 mei 2019 kepada pemilik toko Tungal Tata: Apakah katalog tersebut memberikan efek positif bagi para pelanggan? Informan (bapak H.Royom) menjawab:

"ya mudah sekali, kalau diberi katalog kan nanti warnanya gimana ya jelas perlu sekali, iya (mempercepat)"

2. Peneliti bertanya pada tanggal 2 mei 2019 kepada karyawan toko Tungal Tata:

Apakah katalog tersebut memberikan efek positif bagi para pelanggan?

Informan (mbak Hani) menjawab:

"Orang-orang lebih suka dengan katalog karen bisa memilih warna sesuai gambar dan waranya macam-macam" 
Petanyataan kepada pihak eksternal:

3. Peneliti bertanya pada tanggal 3 mei 2019 kepada konsumen toko Tungal

Tata:

Apa dampak yang diperoleh dengan adanya pelayanan menggunakan katalog?

Informan (bapak Dul Mukti) menjawab:

"ya kalau ada katalog saya bisa milih berbagai macam warna"

4. Peneliti bertanya pada tanggal 3 mei 2019 kepada konsumen toko Tungal Tata:

Apa dampak yang diperoleh dengan adanya pelayanan menggunakan katalog?

Informan (bapak Aryo) menjawab:

"katalog itu mempermudah kita kalau memilih warna, jadi bisa cepet"

5. Peneliti bertanya pada tanggal 3 mei 2019 kepada konsumen toko Tungal Tata:

Apa dampak yang diperoleh dengan adanya pelayanan menggunakan katalog?

Informan (bapak Puji Mulyo) menjawab:

"kalau milih bisa enak" 
6. Peneliti bertanya pada tanggal 3 mei 2019 kepada konsumen toko Tungal Tata:

Apa dampak yang diperoleh dengan adanya pelayanan menggunakan katalog?

Informan (bapak Sarmadi) menjawab:

"ya bisa leluasa milih warna kalau ada katalog"

Toko tunggal tata menggunakan alat berbagai katalog dalam menawarkan salah satu produk yang dijual, yakni katalog cet dengan berbagai jenis, warna, dan merek. Hal itu dibuktikan dari kasil observasi dan dokumentasi serta wawancara yang dilakukan peneliti dengan karyawan toko tunggal tata yakni mbak hani pada tanggal 2 mei 2019 bahwa pelayanan yang diberikan oleh karyawan toko tunggal tata kepada konsumen dengan memberikan katalog.

Sebagaimana yang disampaikan oleh beberapa konsumen maka memberikan dampak positif bagi toko tunggal tata dan pihak konsumen, yaitu terjadi proses penjualan yang cepat dan tepat dalam pemilihan warna sehingga meminimalisir adanya kekeliruan. Proses penjualan yang cepat dan tepat tersebut dirasakan oleh beberapa konsumen.

\subsubsection{Dari Mulut ke Mulut}

Komunikasi antar pelanggan merupakan momen yang sangat penting bagi para penjual, karena pada saat itu terjadi penyampaian informasi baik itu positif ataupun negatif yang diberikan pelanggan kepada konsumen lain. Berikut efek yang diperoleh bagi informan dengan adanya promosi dari mulut ke mulut: 
1. Peneliti bertanya pada tanggal 3 mei 2019 kepada konsumen toko Tungal Tata:

Apakah dengan memperoleh cerita terkait toko tunggal tata memberikan dampak positif?

Informan (bapak Aryo) menjawab:

"iya tentunya, karena saya penasaran dan menghampiri toko ini sehingga saya bisa tau ada toko yang lengkap”

2. Peneliti bertanya pada tanggal 3 mei 2019 kepada konsumen toko Tungal Tata:

Apakah dengan memperoleh cerita terkait toko tunggal tata memberikan dampak positif?

Informan (bapak Puji Mulyo) menjawab:

"ya ini efeknya, saya menjadi pelanggan di toko Tunggal Tata"

3. Peneliti bertanya pada tanggal 3 mei 2019 kepada konsumen toko Tungal Tata:

Apakah dengan memperoleh cerita terkait toko tunggal tata memberikan dampak positif?

Informan (bapak Anto) menjawab:

"saya semenjak tau toko di sini jadi beli terus di sini" 
4. Peneliti bertanya pada tanggal 3 mei 2019 kepada konsumen toko Tungal Tata:

Apakah dengan memperoleh cerita terkait toko tunggal tata memberikan dampak positif?

Informan (bapak Sarmadi) menjawab:

"karena saya penasaran jadi saya datang kesini dan selalu beli di sini"

Berdasarkan wawancara yang dilakukan peneliti kepada beberapa konsuemen telah dibuktikan bahwa masing-masing dari mereka mendapatkan informasi terkait toko bangunan tunggal tata dari rekomendsi teman. Sehingga toko tunggal tata merupakan toko yang mendapatkan dampat positif dari proses promosi yang terjadi antara pelanggan toko tunggal tata dengan konsumen lain. Dampak positif yang diperoleh adalah banyak konsumen baru yang ingin mencoba melakukan pembelian di toko bangunan tunggal tata dan dapat merupah pikiran dari para konsumen malui penyampaian pesan positif terkait toko tunggal tata yang dismpaikan oleh teman yang mereka percaya.

\subsubsection{Temuan di Lapangan}

Melalui pelayanan yang diberikan oleh toko tunggal tata kepada para konsumen melalui sistem hutang, hal itu merupakan tindakan pemberian keringanan bagi para konsumen. Dan karena tidak memberi waktu jatuh tempo secara jelas dengan memberikan kebebasan membayar oleh para konsumen 
tersebut akan memunculkan rasa nyaman karena konsumen merasa bahwa pihak toko tunggal tata memberikan kepercayaan penuh pada masing-masing konsumen.

\subsection{Hambatan dan Solusi dalam Implementasi Bauran promosi}

Pada segala aktivitas yang dijalankan akan memiliki berbagai macam jenis hambatan, dalam melakukan bisnis para pelaku akan memperoleh hambatan pada proses pelaksanaan bisnis yang dijalankan. Namun pada umunya hambatan yang muncul akan dapat diselesaikan melalui tindakan yang menjadi solusi dari permasalahan tersebut, sebagaimana dijelaskan pada firman Allah dalam al-Quran surah Ath-Tholaq ayat 7 yang berbunyi:

Artinya: Allah kelak akan memberikan kelapangan sesudah kesempitan.(Q.S Ath-Tholaq:7)

Maka, dalam segala aspek kehidupan termasuk pada bidang bisnis akan timbul adanya hambatan-hambatan namun akan membantu para pelaku bisnis dari untuk bangit melaui suatu kelapangan yang mudah dari Allah SWT.

\subsubsection{Periklanan}

Periklanan yang sering digunakan para pelaku bisnis sebagai media promosi memiliki berbagai keunggulan. Hal tersebut tidak menutup kemungkinan bahwa dalam pelaksanaan promosi periklanan memiliki berbagai hambatan. 
Namun bedahalnya dengan toko tunggal tata bahwa mereka tidak memiliki hambatan dalam melakukan promosi periklanan.

\section{Pertanyaan kepada pihak Internal:}

1. Peneliti bertanya pada tanggal 1 mei 2019 kepada pemilik toko Tungal Tata: Apa yang menjadi penghambat dalam proses penerapan promosi periklanan pada toko Tunggal Tata dan bagaimana solusinya?

Informan (bapak H.Royom) menjawab:

"pembagian kaos itupun kalau memang orangnya sudah menjadi pelanggan saya, jadi saya beri kaos itupun juga ada nominalnya, seumpama belinya cuma beberapa ratus ribu ya ndak saya kasih, umpama itu kok sampai Rp.2jt atau lebih pasti saya beri kaos, istilahnya jadi ya nambah-nambah kesenangan orang lain juga sponsor karena toko tadi saya tulisi toko saya”

Berdasarkan hasil wawancara tersebut, toko tunggal tata tidak memiliki hambatan dalam promosi periklanan karena pembiayaan yang dikeluarkan sepadan dengan pembelian yang dilakukan oleh para pelanggan.

\subsubsection{Penjualan Pribadi}

Pelayanan dan komunikasi yang terjalin dengan baik secara tatap muka antara penjual dan pembeli merupakan salah satu tindakan penerapan dari promosi penjualan pribadi, dan dalam proses komunikasi antara penjual dan pembeli akan 
mengalami berbagai hambatan. Toko bangunan tunggal tata memiliki hambatan dalam proses promosi penjualan pribadi.

\section{Pertanyaan kepada pihak Internal:}

1. Peneliti bertanya pada tanggal 1 mei 2019 kepada pemilik toko Tungal Tata: Apakah ada hambatan yang diperoleh dengan menerapkan penjualan pribadi dan bagaimana solusinya?

Informan (bapak H.Royom) menjawab:

"sistem anak buah saya kerja itu kan ndak kontrak, jadi umpama kekurangan orang saya ambil orang baru gitu, dan hambatannya itu cuma yang sering terjadi di toko saya anak-anak muda, kemudian nanti setelah 2-3 tahun waktunya nikah ya nikah terus keluar, nah itu hambatan saya sementara itu karena nanti kalau ada orang baru harus mengajari lagi traineng gitu, ya itu yang sering terjadi, solusinya ya itu, solusinya ya ngajari lagi tapi kan ndak ngajari lagi terus menerus "tapi 1-2 bulan kan ikut kawannya yg lama kan bisa juga”,

2. Peneliti bertanya pada tanggal 1 mei 2019 kepada pemilik toko Tungal Tata: Apakah ada hambatan yang diperoleh dengan menerapkan penjualan pribadi dan bagaimana solusinya?

Informan (Mbak Hani) menjawab:

"kendala konsumen yang ribet pernah, kalau mereka cari obat untuk campuran cor itu saya masih belum terlalu paham. Kayak gitu ya tetap 
saya yang melayani tapi saya tanya dulu ke karyawan yang lebih paham, Kayak gitu ya tetap saya yang melayani tapi saya tanya dulu ke karyawan yang lebih paham”.

Maka berdasarkan wawancara tersebut bahwa sistem kerja tanpa kontrak akan menghambat proses pembentukan kematangan skill dari masing-masing karyawan. Sebagaimana dibuktikan dari hasil observasi dan wawancara oleh peneliti kepada karyawan bahwa hambatan yang menjadi kendalan dalam proses promosi penjualan pribadi yang dilakukan karyawan toko tunggal tata adalah pada saat ada produk yang dicari oleh konsumen namun karyawan tersebut tidak memahami atau tidak menguasai tentang produk yang dijual, hal itu sangat menghambat proses pelayanan yang baik sehuingga mengurangi kepercayaan konsumen pada produk yang ditawarkan oleh toko tunggal tata.

Hambatan dari proses penjualan pribadi tersebut membuat karyawan tetap melayani konsumen tersebut dengan berdiskusi terlebih dahulu kepada karyawan lain terhadap manfaat produk yang dijual sehingga proses itu membutuhkan waktu lama, namun hal tersebut merupakan solusi bagi karyawan agar proses penjualan dapat terus berjalan dan konsumen tetap bertahan di toko tunggal tata. Sedangkan solusi yang disampaikan oleh pemilik toko tunggal tata adalah dengan memberikan pengarahan lagi kepada para karyawan namun hal tersebut tidak terjadi terus-menerus karena karyawan sudah mulai memahami tentang produk melalui karyawan lain.

Pada paparan yang disampaikan pemilik toko tunggal tata bahwa hambatan yang muncul dari karyawan yang tidak paham tentang produk adalah 
karena mereka tidak ada kontrak kerja sehingga sulit bagi pihak toko tunggal tata untuk melakukan pengarahan secara maksimal ketika ada karyawan baru.

\subsubsection{Promosi Penjualan}

Promosi penjualan yang dilakukan oleh toko tunggal tata yaitu dengan menggunakan media pemberian hadiah kepada para pelanggan, promosi tersebut dilakukan tanpa muncul adanya hambatan apapun.

Pertanyaan kepada pihak Internal:

1. Peneliti bertanya pada tanggal 1 mei 2019 kepada pemilik toko Tungal Tata: Apakah ada hambatan dalam proses penerapan promosi penjualan? Jika iya, apa solusinya?

Informan (bapak H.Royom) menjawab: "ya sudah saya perhitungkan jadi tidak pernah ada kendala"

Sehingga dapat dinyatakan bahwa dalam proses promosi penjualan dengan media yang digunakan oleh toko tunggal tata tersebut berjalan dengan lancar dan tersampaikan dengan baik kepada konsumen tanpa adanya kerugian dari pihak toko tunggal tata, maka toko tunggal tata tidak memiliki hambatan pada proses promosi ini.

\subsubsection{Pemasaran Langsung}

Pada toko tunggal tata, alat pemasaran langsung yang duigunakan sebagai promosi adalah katalog. Dengan adanya katalog akan mempermudah konsumen 
dalam memilih produk yang diinginkan sesuai gambar yang disediakan pada katalog. Dalam proses ini juga tidak memiliki hambatan sebagaimana disampaikan oleh pihak internal toko Tunggal Tata:

Pertanyaan kepada pihak Internal:

1. Peneliti bertanya pada tanggal 1 mei 2019 kepada pemilik toko Tungal Tata:

Apakah ada hambatan yang diperoleh dengan menerapkan pemasaran langsung, kemudian bagaimana solusinya?

Informan (bapak H.Royom) menjawab:

"Kalau cat itu sudah ditutu terus dibuka d irumah, siapa tau di rumah itu tadi dikurangi aja atau terus warnanya nggak cocok sudah saya beritahu tidak boleh kembali"

2. Peneliti bertanya pada tanggal 1 mei 2019 kepada karyawan toko Tungal Tata:

Apakah ada hambatan yang diperoleh dengan menerapkan pemasaran langsung, kemudian bagaimana solusinya?

Informan (mbak Hani) menjawab:

"selama ini tidak ada yang kecewa dengan warna cat yang dipilih dari katalog karena warna di katalog sesuai dengan cat aslinya”

Pada pemaparan katalog yang dilakukan oleh karyawan toko tunggal tata sebagai alat pemasaran langsung tersebut tidak mengalami hambatan karena apabila terjadi kekeliruan atau ketidaksesuaian yang dirasakan oleh konsumen merupakan kejadian diluar tanggung jawab pihak toko tunggal tata karena diawal 
telah dilakukan perjanjian bahwa untuk produk cat yang sudah dibuka segelnya maka produk tidak bisa dikembalikan dan hal tersebut merupakan kecerobohan dari pikah konsumen tersebut. Dan warna yang disediakan pada kataong selalu sama dengan warna asli dalam kaleng cat.

\subsubsection{Dari Mulut Ke Mulut}

Promosi melalui komunikasi antara pelanggan dengan konsumen lain yang merupakan promosi efektif dan efisien tersebut hanya memberikan dampak positif bagi pihak toko tunggal tata. Bahkan tidak ada hambatan apapun karena promosi ini berjalan mengalir secara spontan dari keantusiasan yang dimiliki para pelanggan toko tunggal tata sehingga untuk menyalurkan informasi kepada para temannya.

Oleh karena itu, komunikasi dari mulut ke mulut merupakan kejadian sepontan dari pihak pelanggan kepada para konsumen lain sebagai bentuk kesolidan untuk membaguikan pengalaman membeli yang menyenangkan dan memuaskan.

\subsubsection{Temuan di Lapangan}

Berdasakan hasil wawancara peneliti kepada konsumen toko tunggal tata yang menerima peayanan meng-hutang tanpa ada jatuh tempo yang pasti maka dari pihak toko bangunan tunggak tata memiliki beberapa hambatan, sebagaimana wawancara yang peneliti lakukan pada pemilik toko bangunan tunggal tata sebagai berikut: 
Pertanyaan pihak internal:

1. Peneliti bertanya pada tanggal 1 mei 2019 kepada pemilik toko Tunggal Tata: Apakah ada kendala dengan adanya pemberian hutang tersebut, kemudian bagaimana solusinya?

Informan (bapak H.Royom) menjawab:

"kadang-kadang kan nggak pake anggunan, ya kadang-kadang ada orang yang 2 bulan selesai terus totalan tapi kadang totalannya kurang terus molor sampai setengah bulan atau satu bulan ya juga ada, nah itu tantangan yang selalu saya hadapi. Solusinya ya" solusinya itu kalau lama kelamanan dan itu nominal banyak itu saya datangi terus saya pakai perjanjian ya otomatis ttd perjanjian dgn matrai."

Pernyataan yang diungkapkan oleh pemilik toko tunggal tata dapat disimpulkan bahwa dalam memberikan keringanan membayar oleh konsumen tanpa ada kepastian jatuh tempo memiliki hambatan, yakni terjadinya telat bayar dari pihak konsumen, dan solusi yang dilakukan oleh pemilik toko bangunan tunggal tata dengan membuat surat perjanjian kepada konsumen tersebut. 


\section{BAB V \\ PENUTUP}

\subsection{Kesimpulan}

Berdasarkan permasalahan yang telah dirumuskan pada bab 1 dan berdasarkan hasil penelitian yang telah dipaparkan oleh peneliti pada bab V, maka dapat disimpulkan bahwa:

1. Implementasi atau penerapan yang dilakukan oleh toko bangunan tunggal tata pada bauran promosi tersebut menggunakan lima elemen bauran promosi diantaranya adalah: periklanan, penjualan prbadi, promosi penjualan, pemasaran langsung, dan promosi darui mulut ke mulut. Pada penerapannya toko tunggal tata menggunakan kaos berlogo "toko tunggal tata" sebagai alat promosi periklanan, menggunakan sistem pelayanan yang baik sebagai alat penjualan pribadi, dan menggunakan pemberian reward berupa hadiah-hadiah sebagai alat promosi penjualan, kemudian menggunakan katalog sebagai alat pemasaran langsung, serta promosi dari mulut ke mulut yang terjadi secara spontan oleh para konsumen. Berdasarkan paparan tersebut maka elemen promosi yang tidak diterapkan

oleh toko bangunan tunggal tata adalah promosi melalui hungungan masuyarakat. Kemudian toko tunggal tata melakukan penerapan pelayanan lain yaitu pemberian hutang kepada para konsumen dan merupakan pelayanan yang tidak termasuk dalam bauran promosi. 
2. Malalui lima elemen bauran promosi dan satu pelayanan diluar bauran promosi yang diterapkan oleh toko bangunan tunggal tata, maka toko tunggal tata mendapatkan berbagai macam dampak positif diantaranya: melalui promosi periklanan maka akan menambah jumlah pelanggan dengan datangnya pelanggan baru, kemudian dengan penjualan pribadi maka komunikasi lancar dan konsumen akan merasa nyaman dan puas, promosi penjualan yang dilakukan toko tunggal tata dengan memberikan rewar kepada konsumen akan membuat konsumen puas dan memilih bertahan untuk tetap menjadi pelanggan dan memunculkan motivasi para pelanggan untuk melakukan pembelian dalam jumlah besar, dan dengan pembelian barang yang bervolume besar maka pelayanan dilakukan oleh karyawan toko bangunan tunggal tata melalui pemasaran langsung dengan menyediakan katalog. Selain itu promosi dari mulut kemulut juga memberikan dampak positif bagi toko tunggal tata yaitu dengan bertambahnya jumlah konsumen yang datang. Bahkan pelayanan pemberian hutang oleh toko bangunan tunggal tata untuk pada konsumen memberikan dampak kepada mereka untuk tetap menjadi pelanggan tetap di toko bangunan tunggal tata.

3. Hambatan yang diperolah toko tunggal tata dalam penerapan bauran promosi adalah hanya pada elemen promosi penjualan pribadi, yaitu dalam proses penjualan tersebut karyawan kurang mamahami tentang spesifikasi produk yang ditawarkan sehigga mengakibatkan proses pelayanan menjadi terhambat dan solusi yang dilakukan adalah dengan bertanya kepada 
karyawan lain kemudian proses pelayanan berjalan kembali. Kemudian hambatan terjadi ketika pelayana pemberian hutang dilakukan oleh pihak toko bangunan tunggal tata yakni modal yang diperoleh tidak kembali secara cepat sehingga menghambat proses kulakan dalam jumlah besar dan solusi yang lakukan adalah dengan meminta pinjaman pada pihak bank.

\subsection{Saran}

Berdasarkan hasil penelitian yang dilakukan peneliti melalui proses turun lapangan tersebut maka peneliti ingin memberikan saran terkait implementasi bauran promosi agar dapat diterapkan lebih tepat dan memberikan dampak yang lebih besar pada volume penjualan yang diperoleh, saran tersebutsebagai berikut:

1. Untuk Toko bangunan Tunggal Tata

Semakin berkembangnya era digital pada zaman ini maka sebaiknya toko tunggal tata memanfaatkan media tersebut dalam proses promosi periklanan sehingga lebih menghemat biaya dan waktu serta dapat meningkatkan jumlah konsumen yang datang. Kemudian seharusnya memberikan pengarahan secara tepat dan jelas kepada para karyawan baru sebelum masa percobaan sehingga ketika para koaryawan mulai berkomunikasi langsung dengan pelanggan tidak menghambat terjadinya proses pelayanan yang baik. Dan sebaiknya pada penerapan pemasaran langsung maka pihak toko tunggal tata memanfaatkan alat komunikasi telepon sebagai media promosi kepada pelanggan lama, misalnya 
memberikan informasi kepada pelanggan bahwa ada barang terbaru yang sedang dijual. Sedangkan dalam proses pelayanan pemberian hutang kepada konsumen seharusnya diberikan kepastian jatuh tempo atau diberikan waktu pembayaran secara bertahap secara jelas agar modal yang diperoleh toko tunggal tata dapat cepat kembali dan dapat digunakan tanpa harus melakuka pinjaman kepada pihak perbankan, serta apabila jumlah hutang yang diberikan kepada konsumen dalam jumlah yang cukup besar maka alangkah baiknya jika pihak toko tujggal tata memberikan jaminan agar resiko yang akan muncul tidak terlalu besar.

2. Untuk peneliti selanjutnya

Penelitian yang akan dilakukan diwaktu mendatang, agar peneliti dapat meneruskan penelitian di toko bangunan tungga tata maka diharapkan mengungkapkan faktor lain sehingga toko bangunan tunggal tata mampu meningkatkan volume penjualan. 


\section{DAFTAR PUSTAKA}

Afrianti, Nova \& Yunaldi. (2012). Peranan Promosi Perpustakaan Terhadap Kunjungan Pemustaka di Perpustakaan Umum Kota Solok. Jurnal Ilmu Informasi Perpustakaan dan Kearsipan. Vol 1. 9-16

Al Idrus, Salim. (2017). Strategi Pembelajaran Kewirausahaan: Aplikasi Pembelajaran Mata Kuliah Kewirausahaan di Perguruan Tinggi. Malang: Media Nusa Creative

Al Idrus, Salim. (2018). Model Pengelolaan Koperasi Berbasis Kinerja: Sebuah Uji Transformasi Model Model Konseptual. Malang: Media Nusa Creative

Arianty, Nel. (2014). Pengaruh Bauran Promosi Terhadap Volume Penjualan Sepeda Motor Yamaha Mio Pada PT. Alfa Scorpii Sentral Yamaha. Jurnal Riset Akuntansi dan Bisnis. Vol 14. 98-110

Asnawi, Nur \& Muhammad Asnan F. (2017).Pemasaran Syariah: Teori, filosofi, dan isu-isukontemporer. Jakarta: Raja Grafindo Persada

Basu Swastha \& Irawan. (2005).Asas-asas Marketing.Yogyakarta:Liberty

Cahyadi, Karnia \& Rendy Iswanto. (2013). Perencanaan Media Promosi Event sebagai Strategi Promosi Lorraine-DIY Invitation di Surabaya. Vol 2. 28-42

Creswell, Jhon W. (2015). Penelitian Kualitatif \& Desain Riset: Memilih diantara Lima Pendekatan. Yogyakarta: Pustaka Belajar

Dharmmesta, Basu Swasta. (2014). Manajemen Pemasaran. Tanggerang Selatan: Universitas Terbuka

Gulo, W. (2000). Metodologi Penelitian. Grasindo

Gunara, Thorik \& Utus H Sudipyo. (2008). Marketing Muhammad: Strategi Andalan dan Jitu Praktik Bisnis Nabi Muhammad SAW. Bandung: Karya Kita

Hasan, Ali . (2013). Marketing dan Kasus-Kasus Pilihan. Yogyakarta. CAPS (Center For Academic Publishing Service)

Hasan, Ali. (2010). Marketing dari Mulut ke Mulut. Yogyakarta: Media Pressindo

Hermawan, Agus. (2012). Komunikasi Pemasaran. Jakarta Erlangga

Huda, Nurul dkk. (2017). Pemasaran Syariah: Teori dan Aplikasi. Depok:Kencana

Ismaya, Sujana. (2007). Kamus Besar Ekonomi. Bandung : Pustaka Grafika 
Kotler, Philip. (1999). Marketing Jilid 1. Jakarta: Erlangga

Kotler, Philip \& Gary Armstrong. (2014). Principle Of Marketing, 15th edition. New Jersey: Pearson Prentice Hall.

Kotler, Philip. (2003). Marketing Insights From A to Z: 80 konsep yang harus dipahami setiap manajer. Jakarta: Erlangga

Kotler, Philip.(2005). Manajemen pemasaran jilid 1 \& 2.Jakarta: Indeks

Kotler, Pilip \& Gray Armstrong. (2003).Dasar-dasar Pemasaran Jilid 1, Edisi Kesembilan. Penerbit PT. Indeks Gramedia, Jakarta

Lupiyoadi, Rambat. (2001). Manajemen Pemasaran Jasa. Jakarta : PT. Salemba Empat.

Label, W.Charles. (2001). Pemasaran. Jakarta: Salemba Empat.

Madura, Jeff. (2007). Pengantar Bisnis, Edisi 4. Jakarta: Salemba Empat

Mursid, M. (2006). Manajemen Pemasaran. Jakarta: Bumi Aksara

Onggo, Olivia, dkk. Perencanaan Promosi Transportasi Wisata di Kota Solo. 112

Poerwondari, E. Kristi. (2005). Metodologi Penelitian untuk Penelitian Perilaku Manusia. Jakarta: Lembaga pengembangan Saran Pengukuran dan Pendidikan Psikologi Fakultas Psikologi Universitas Indonesia.

Purhantar, Whyu. (2010). Metode Penelitian Kualitatif untuk Bisnis. Yogyakarta: Graha Ilmu

Rangkuti, Freddy. (2009).Strategi Promosi yang kreatif \& Analisis Kasus Intregrated Marketing Comunication

Salim, Agus. (2006). Teorui dan Paradigma Penelitian Sosial. Yogyakarta:Tiarawacana

Simamora, Henry. (2000). Manajemen Pemasaran Internasional. Jakarta:Salemba Empat

Sutopo, HB. 2006. Metode Penelitian Kualitatif. Surakarta: UNS Press

Tjiptono, Fandy. (1997). Strategi Pemasaran. Yogyakarta: ANDI

Usman, Husaini dan Purnomo Setiady Akbar. (2006). Metodologi Penelitian Soaial. Jakarta: Bumi Aksara

Usman, Husaini dan Purnomo Setiady Akbar. (2009). Metodologi Penelitian Soaial. Jakarta: Bumi Aksara 
Wilson, Michael T. (1983). Manajemen Armada Penjualan. Jakarta: Pustaka Binaman Presindo

Yin, Robert K. (2014). Studi Kasus: Desain dan Metode. Jakarta: Rajawali Pers. https://www.jurnal.id/id/blog/2017/5-keuntungan-membuka-bisnis-tokobangunan, diakses 02 Desember 2018

http://www.kemenperin.go.id/artikel/7889/Pengembangan-Industri-BahanBangunan-yang-Ramah-Lingkungan, diakses 02 Desember 2018 https://tafsir.learn-quran.co/id diakses 08 Maret 2019 


\section{Lampiran 1. Instrumen Penelitian}

\section{INSTRUMEN OBSERVASI}

Implementasi Bauran Promosi dalam upaya Meningkatkan Volume Penjualan pada Toko Bangunan Tunggal Tata di Tuban Jawa Timur

\begin{tabular}{|c|c|}
\hline Fokus Observasi & Jenis Kegiatan yang akan di Observasi \\
\hline \multirow[t]{3}{*}{$\begin{array}{l}\text { Implementasi Bauran Promosi dalam } \\
\text { meningkatkan volume penjualan }\end{array}$} & $\begin{array}{l}\text { 1. Pemilik } \\
\text { - Penerapan Kebijakan dalam } \\
\text { melakukan Promosi }\end{array}$ \\
\hline & $\begin{array}{l}\text { 2. Karyawan } \\
\quad \bullet \quad \text { Proses pelayanan }\end{array}$ \\
\hline & $\begin{array}{l}\text { 3. Konsumen } \\
\qquad \begin{array}{l}\text { • Jumlah Konsumen } \\
\bullet \quad \text { Barang yang dibeli }\end{array}\end{array}$ \\
\hline
\end{tabular}

Sumber: Data diolah peneliti

\section{PEDOMAN WAWANCARA}

Implementasi Bauran Promosi dalam upaya Meningkatkan Volume Penjualan pada Toko Bangunan Tunggal Tata di Tuban Jawa Timur

Hari: Rabu, 01 Mei 2019

Lokasi: Toko Tunggal Tata

Pemilik Toko

Informan 1:

1. Nama pemilik toko tunggal tata?

"Bapak H.Royom"

2. Bagaimana Sejarah, struktur organisasi, visi dan misi toko Tunggal Tata?

(sesuai penjelasan di Bab 4.1) 


\section{Bagaimana penerapan promosi?}

a. Periklanan: (komunikasi impersonal untuk memberikan informasi kepada pembeli)

"Tidak pernah, ya memangnya kami sebagai yang punya toko. Sponsor itu sekarang ini hanya sekedar kaos dan saya tulisi toko saya, kemudian selain itu ya lewat orang-orang itu ya temen-temen itu, jadi sementara ini ya ndak pake sponsor lain istilahnya"

b. Penjualan Pribadi:(komunikasi secara tatap muka antara penjual dan calon pembeli)

"Ya itu penting sekali (pelayanan) dan perlu karena pelayanannya itu saya tekankan kepada anak buah saya itu harus bagaimana ya, pokoknya harus kalau disini tuh namanya sumeh, setiap ada orang pembeli tuh harus cepat-cepat ditanggapi gitu, kalo ada yang datang seakan-akan itu belum masuk di ruangan penjual itu sudah di songsong gitu lo, ditanggapi gitu lo, ya mungkin itu termasuk promosi juga, terus anak buah saya itu saya tekankan jangan terlalu keras, maksunya itu harus lemahlembut, ramah"

c. Promosi Penjualan: (promosi persuasi dengan menggunakan insentif

untuk menarik pembeli)

"yang ada itu kadang-kadang membeli suatu barang contoh ya ini seumpama beli baut akhirnya di bawa pulang dan ternyata nggak cocok, nah saya pesan (pak kalau ini ndak cocok ya di kembalikan tapi dengan syarat tidak rusak). Kalau diskon atau hadiah itu endak, tapi kalau seumpama nominal Rp.40-jutaan atauRp. 30-jutaan itu biasanya ya diberi kenang-kenangan diberi kompor seharga $R p$. 400rb atau kipas angin seharga Rp. 200rb. Nah ini yang penting lagi saya kan di desa, didesa itu kan ada banyak orang teman-teman atau tetangga-tenagga itu kalau berhubungan sosial itu ya itu juga saya pake, bukan cuma hadiah-hadiah itu saja. Itu kalau di desa itu terpenting kalau di kota memangnya ndak ada itu kalau promonya besar-besaran kemudian orang kenal, kalau di kota kan itu tau toko ini-toko ini, kalau di desa kan enggak 
d. Hubungan Masyarakat: (komunikasi untuk mendorong opinui dari berbagai kelompok)

"Ya itu tadi dengan melakukan pelayanan yang baik dan bersikap ramah kepada para pelanggan"

e. Pemasaran Langsung: (sistem komunikasi pemasaran bersifat interaktif)

"Iya, ya ada katalog warna cat"

4. Implikasi apa yang diperoleh?

"ya lumayan (menambah pelanggan) tapi hanya beberapa persen saja karena toko saya kan di desa jadi mudah diketahui sama orang banyak, lain di kota kan banyak toko jadi yang ini jual ini kan agak sulit, kalo ini kan enggak, toko mudak diketahu orang banyak. Dan iya menimbulkan dampak positif, kan nanti komunikasi bisa lancar dan konsumen merasa puas. Pelanggan kalau dikasih kenang-kenangan seperti itu ya para pelanggan termotivasi untuk membeli barang dengan jumlah yang lebih banyak. Meduia promosi menggunakan katalog ya mudah sekali, kalau diberi katalog kan nanti warnanya gimana ya jelas perlu sekali, iya (mempercepat)

5. Hambatan apa yang didapatkan dalam proses penjualan dan bagaimana solusinya?

"Dalam pembagian kaos itupun kalau memang orangnya sudah menjadi pelanggan saya, jadi saya beri kaos itupun juga ada nominalnya, seumpama belinya cuma beberapa ratus ribu ya ndak saya kasih, umpama itu kok sampai Rp.2jt atau lebih pasti saya beri kaos, istilahnya jadi ya nambah-nambah kesenangan orang lain juga sponsor karena toko tadi saya tulisi toko saya.

Ada hambatan pada penualan pribadi mbak, sistem anak buah saya kerja itu kan ndak kontrak, jadi umpama kekurangan orang saya ambil orang baru gitu, dan hambatannya itu cuma yang sering terjadi di toko saya anak-anak muda, kemudian nanti setelah 2-3 tahun waktunya nikah ya nikah terus keluar, nah itu hambatan saya sementara itu karena nanti kalau ada orang baru harus mengajari lagi traineng gitu, ya itu yang sering terjadi, sehingga solusi yang dilakuukan adalah ya itu, solusinya ya 
ngajari lagi tapi kan ndak ngajari lagi terus menerus "tapi 1-2 bulan kan ikut kawannya yg lama kan bisa juga.

ya sudah saya perhitungkan untuk pemberian kenang-kenangan jadi tidak pernah ada kendala. Sementara untuk katalog selama ini tidak ada yang kecewa dengan warna cat yang dipilih dari katalog karena warna di katalog sesuai dengan cat aslinya.

6. Penemuan Lapangan (berdasarkan observasi bahwa pihak toko tunggal tata menerima sistem hutang"

"Gini, kalau itu bukan melayani hutang, tapi cuma gini biasanya pembeli saya kan itu seorang pegawai, pegawai itu kan ndak tiap hari di rumah kemudian kan pembangunan itu kan kadang kurang ini kurang itu nah kadang-kadang oragnya itu titip uang ke saya kemudian tukangnya tingal minta barang ke saya gitu saja terus totalan itu belakang iutu yang maksudnya hutang. Kalau sudah selesai banguunan dikerjakang maka sibos tadi baru bayar ke saya.kadang-kadang kan nggak pake anggunan, ya kadang-kadang ada orang yang 2 bulan selesai terus totalan tapi kadang totalannya kurang terus molor sampai setengah bulan atau satu bulan ya juga ada, nah itu tantangan yang selalu saya hadapi. Solusinya ya" solusinya itu kalau lama kelamanan dan itu nominal banyak itu saya datangi terus saya pakai perjanjian ya otomatis ttd perjanjian dgn matrai."

Hari: Kamis, 02 Mei 2019

Lokasi: Toko Tunggal Tata

Karyawan

Informan 2:

1. Dengan Mbak siapa?

"Mbak Hani"

2. Sudah berapa lama menjadi karyawan di toko Tunggal Tata?

"Kurang lebih 1 tahun"

3. Bagaimana penerapan promosi periklanan di toko Tunggal Tata, dengan adanya penerapan tersebut apa yang diperoleh atau apa efek 
yang didapatkan, dan apakah ada kendala kemudian bagaimana solusinya?

“Untuk promosi lewat sosial media atau sponsor-sponsor seperti itu tidak pernah"

4. Bagaimana penerapan penjualan pribadi / proses pelayanan yang dilakukan oleh penjual kepada pembeli, dengan adanya penerapan tersebut apa yang diperoleh atau apa efek yang didapatkan, dan apakah ada kendala kemudian bagaimana solusinya?

"ya misal kalau pembeli itu datang terus saya layani mau cari apa, kalau saya pelayanannya bagus ya mereka yang beli pasti senang. Kemudian kendala konsumen yang ribet pernah, kalau mereka cari obat untuk campuran cor itu saya masih belum terlalu paham. Kayak gitu ya tetap saya yang melayani tapi saya tanya dulu ke karyawan yang lebih paham"

5. Bagaimana penerapan promosi penjualan yang dilakukan toko tunggal tata/ untuk mendorong konsumen lebih tertarik dengan toko Tunggal Tata, dengan adanya penerapan tersebut apa yang diperoleh atau apa efek yang didapatkan, dan apakah ada kendala kemudian bagaimana solusinya?

"kalau belinya banyuak sih biasanya dikasih hadiah, dan biasanya kalau ada hadiah jadinya orang-orang ngeborong barang biar dapet hadiah itu"

6. Bagaimana implementasi yang diterapkan toko Tunggal tata dalam memasarkan produk secara langsung? Apa mungkin melalui katalog, pesan email, ataupun telepon, dengan adanya penerapan tersebut apa yang diperoleh atau apa efek yang didapatkan, dan apakah ada kendala kemudian bagaimana solusinya?

"orang kalau cari cat saya beri katalog original, tapi semisal tidak cocok ya saya kasih cat oplosan yang warnanya lebih bagus, nanti saya oplos 
sendiri. Sekarang uini Orang-orang lebih suka dengan katalog karen bisa memilih warna sesuai gambar dan waranya macam-macam. Dan selama ini tidak ada yang kecewa dengan warna cat yang dipilih dari katalog karena warna di katalog sesuai dengan cat aslinya"

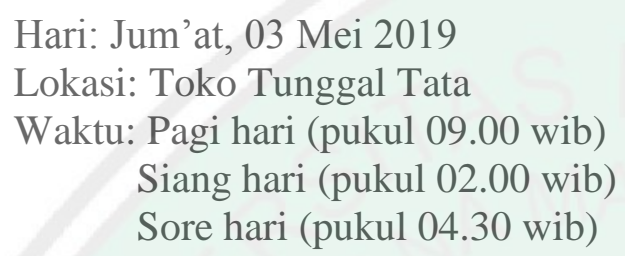

1. Dengan Bapak siapa?

"Bapak Dul Mukti"

2. Dimana tempat tinggal bapak?

"Desa Sembungrejo, Semampir"

3. Bagaimana penerapan promosi periklanan di toko Tunggal Tata, dengan adanya penerapan tersebut apa yang diperoleh atau apa efek yang didapatkan?

"Tidak ada mbak kalau iklan-iklan seperti di televisi itu"

4. Bagaimana penerapan penjualan pribadi / proses pelayanan yang dilakukan oleh penjual kepada pembeli, dengan adanya penerapan tersebut apa yang diperoleh atau apa efek yang didapatkan?

"untuk pelayanan di toko Tunggal Tata ini saya rasa sangat bagus sekali, ramah dan tamah, sering senyum mbak sehingga sudah lama mbak, sudah berapa tahun(penegasan) menjadi pelanggan di simi" 
5. Bagaimana penerapan promosi penjualan yang dilakukan toko tunggal tata/ untuk mendorong konsumen lebih tertarik dengan toko Tunggal Tata, dengan adanya penerapan tersebut apa yang diperoleh atau apa efek yang didapatkan?

"Barang yang saya pesen langsung dianter, kalau saya beli di sini itu barangnya langsung diantar mbak, jadi tidak menunggu lama”,

6. Bagaimana implementasi yang diterapkan toko Tunggal tata dalam memasarkan produk secara langsung? Apa mungkin melalui katalog, pesan email, ataupun telepon, dengan adanya penerapan tersebut apa yang diperoleh atau apa efek yang didapatkan?

"Ada mbak, ini juga saya beli cat milih dari katalog, ya kalau ada katalog saya bisa milih berbagai macam warna"

7. Dari manakah mendapatkan informasi tentang Toko Tunggal Tata, apakah dengan memperoleh informasi tersebut memiliki dampak positif?

"Saya mengenal toko ini dari inisiatif sendiri (berkunjung di toko Tunggal Tata), memang dulunya toko ini sangat kecil ternyata lamalama toko ini kok menjadi besar"

8. Apa perbedaan toko Tunggal Tata dengan toko lain?

"Toko bangunan ini saya rasa perbedaannya sangat banyak sekali dengan toko yang lain mbak, terutama pembayaranya kalau kurang itu bisa istilahe ngutang lah, kalau di bangunan ini contohnya saya baru mau renovasi rumah ini untuk dana kurang ini bisa saya minta keringanan alias ngutang" 
Informan 4:

\section{Dengan Bapak siapa?}

"Bapak Aryo"

2. Dimana tempat tinggal bapak?

\section{"Desa Senori mbak"}

3. Bagaimana penerapan promosi periklanan di toko Tunggal Tata, dengan adanya penerapan tersebut apa yang diperoleh atau apa efek yang didapatkan?

"kan banyak dari brosur kaos-kaos yang ada tulisannya toko ini kan, kalau untuk sosial media belum pernah melihat sih, dengan adanya gambar toko dimanaa-mana ya pastinya membuat saya tergugah untuk datang ke toko Tunggal Tata karena rasa penasaran ini”

4. Bagaimana penerapan penjualan pribadi / proses pelayanan yang dilakukan oleh penjual kepada pembeli, dengan adanya penerapan tersebut apa yang diperoleh atau apa efek yang didapatkan?

"Pelayanannya juga bagus, pokoknya cocoknya disini, makanya saya sudah bertahun-tahun langganan disini mbak"

5. Bagaimana penerapan promosi penjualan yang dilakukan toko tunggal tata/ untuk mendorong konsumen lebih tertarik dengan toko Tunggal Tata, dengan adanya penerapan tersebut apa yang diperoleh atau apa efek yang didapatkan?

"Kalau kita beli volumenya agak banyak kan dianter sampai tempat, saya tetap bertahan disini, karena dibanding dengan toko lain malah biasanya barang tidak diantar kalau pesan sedikit"

6. Bagaimana implementasi yang diterapkan toko Tunggal tata dalam memasarkan produk secara langsung? Apa mungkin melalui katalog, 
pesan email, ataupun telepon, dengan adanya penerapan tersebut apa yang diperoleh atau apa efek yang didapatkan?

"pelayanannya melalui katalog memang ada, biasanya saya memilih warna dari katalog yang disediakan dengan berbagai merek, katalog itu mempermudah kita kalau memilih warna, jadi bisa cepet"

7. Dari manakah mendapatkan informasi tentang Toko Tunggal Tata, apakah dengan memperoleh informasi tersebut memiliki dampak positif?

"mendapatkan informasi tentang toko ini pertama dari temen yang cerita, pernah juga ada temen yang sempat tanya (tentang toko ini) juga saya kasih tau, iya tentunya, karena saya penasaran dan menghampiri toko ini sehingga saya bisa tau ada toko yang lengkap"

8. Apa perbedaan toko Tunggal Tata dengan toko lain?

"Toko bangunan ini saya rasa perbedaannya ya itu tadi, barangnya lengkap, kemudian kalau pesan itu barangnya langsung di anter"

Informan 5:

1. Dengan Bapak siapa?

“Bapak Puji Mulyo”

2. Dimana tempat tinggal bapak?

"Desa Pong-pongan"

3. Bagaimana penerapan promosi periklanan di toko Tunggal Tata, dengan adanya penerapan tersebut apa yang diperoleh atau apa efek yang didapatkan?

"Sosial media, belum pernah" 
4. Bagaimana penerapan penjualan pribadi / proses pelayanan yang dilakukan oleh penjual kepada pembeli, dengan adanya penerapan tersebut apa yang diperoleh atau apa efek yang didapatkan?

"lumayan bagus (pelayanan), cepat, dan sudah lama mbak, langganan disini sudah lama sekali"

5. Bagaimana penerapan promosi penjualan yang dilakukan toko tunggal tata/ untuk mendorong konsumen lebih tertarik dengan toko Tunggal Tata, dengan adanya penerapan tersebut apa yang diperoleh atau apa efek yang didapatkan?

"apa ya, ya mungkin karena barangnya lengkap, karena barangnya lengkap jadi saya tidak perlu repot-repot ke toko lain”

6. Bagaimana implementasi yang diterapkan toko Tunggal tata dalam memasarkan produk secara langsung? Apa mungkin melalui katalog, pesan email, ataupun telepon, dengan adanya penerapan tersebut apa yang diperoleh atau apa efek yang didapatkan?

"tidak pernah sih ada promosi masuk dari telepon, tapi untuk katalog biasanya ada untuk warna cat, jadi kalau milih bisa enak”

7. Dari manakah mendapatkan informasi tentang Toko Tunggal Tata, apakah dengan memperoleh informasi tersebut memiliki dampak positif?

"tau tentang toko ini pertama kali dari temeb, dari temen-temen kerja, ya ini efeknya, saya menjadi pelanggan di toko Tunggal Tata"

8. Apa perbedaan toko Tunggal Tata dengan toko lain?

"Toko bangunan ini saya rasa perbedaannya ya itu tadi, barangnya lengkap, harganya juga bersaing" 
Informan 6:

1. Dengan Bapak siapa?

\section{"Bapak Anto"}

2. Dimana tempat tinggal bapak?

\section{"Tuban Kota"}

3. Bagaimana penerapan promosi periklanan di toko Tunggal Tata, dengan adanya penerapan tersebut apa yang diperoleh atau apa efek yang didapatkan?

“nggak pernah, nggak pernah" (melihat dari brosur/sosial media)

4. Bagaimana penerapan penjualan pribadi / proses pelayanan yang dilakukan oleh penjual kepada pembeli, dengan adanya penerapan tersebut apa yang diperoleh atau apa efek yang didapatkan?

"di sini pelayanannya tepat, cepat, makanya saya menjadi pelanggan disini sudah tiga tahun"

5. Bagaimana penerapan promosi penjualan yang dilakukan toko tunggal tata/ untuk mendorong konsumen lebih tertarik dengan toko Tunggal Tata, dengan adanya penerapan tersebut apa yang diperoleh atau apa efek yang didapatkan?

"Kalau diskon sih nggak pernah"

6. Bagaimana implementasi yang diterapkan toko Tunggal tata dalam memasarkan produk secara langsung? Apa mungkin melalui katalog, 
pesan email, ataupun telepon, dengan adanya penerapan tersebut apa yang diperoleh atau apa efek yang didapatkan?

"untuk saat ini saya belum pernah membeli barang yang ada katalognya, dan tidak pernah menerima promosi dari telepon"

7. Dari manakah mendapatkan informasi tentang Toko Tunggal Tata, apakah dengan memperoleh informasi tersebut memiliki dampak positif?

"Dari temen (mengetahui informasi tentang toko ini) desa Temandang. Dan saya semenjak tau toko di sini jadi beli terus di sini”,

8. Apa perbedaan toko Tunggal Tata dengan toko lain?

"kalau beli disini bisa hutang, nggak pernah dikasih jatuh tempo tapi dari pihak kita sendiri setiap satu bulan sekali satu minggu sekali memberi uang"

Informan 7:

1. Dengan Bapak siapa?

"Bapak Sarmadi”

2. Dimana tempat tinggal bapak?

"Tuban Kota"

3. Bagaimana penerapan promosi periklanan di toko Tunggal Tata, dengan adanya penerapan tersebut apa yang diperoleh atau apa efek yang didapatkan?

"ya kalau tentang iklan saya tidak pernah melihat" 
4. Bagaimana penerapan penjualan pribadi / proses pelayanan yang dilakukan oleh penjual kepada pembeli, dengan adanya penerapan tersebut apa yang diperoleh atau apa efek yang didapatkan?

"disini toko ini pelayanannya ramah, terus bosnya juga supel orangnya, wong Saya disini sudah lama mbak"

5. Bagaimana penerapan promosi penjualan yang dilakukan toko tunggal tata/ untuk mendorong konsumen lebih tertarik dengan toko Tunggal Tata, dengan adanya penerapan tersebut apa yang diperoleh atau apa efek yang didapatkan?

"Kita kalau sering di toko Tunggal Tata ini, biasanya kalau istilahnya ya kita ngambil barang barang, kita bisa bayar lunas maka dapat Fee, istilahnya ya diberi kipas angin, entah jaket gitu mbak, dengan adanya pemberian Fee tadi ya membuat saya bertahan"

6. Bagaimana implementasi yang diterapkan toko Tunggal tata dalam memasarkan produk secara langsung? Apa mungkin melalui katalog, pesan email, ataupun telepon, dengan adanya penerapan tersebut apa yang diperoleh atau apa efek yang didapatkan?

"ya mbak, saya biasanya membeli cat ya milihnya dari katalog itu, dan warnanya ada macam-macam, ya bisa leluasa milih warna kalau ada katalog"

7. Dari manakah mendapatkan informasi tentang Toko Tunggal Tata, apakah dengan memperoleh informasi tersebut memiliki dampak positif?

"teman-teman mbak, banyak yang bilang kalau toko Tunggal Tata itu lengkap, karena saya penasaran jadi saya datang kesini dan selalu beli di sini"

\section{Apa perbedaan toko Tunggal Tata dengan toko lain?}


“yang paling penting mbak bisa ngutang, kalau kita punya dana ada kurangnya, itu biasanya nitip, terus nanti kalau mbangun udah selesai itu biasanya ya dari toko Tunggal Tata tidak memberi jatuh tempo tetapi kita yang punya inisiatif sendiri (untuk membayar)" 


\section{INSTRUMEN DOKUMENTASI}

Implementasi Bauran Promosi dalam upaya Meningkatkan Volume Penjualan pada Toko Bangunan Tunggal Tata di Tuban Jawa Timur

\begin{tabular}{|l|l|l|}
\hline Dokumentasi & a. Pengambilan gambar & $\begin{array}{l}\text { Keadaan Toko } \\
\bullet\end{array}$ \\
\hline & b. Pktivitas Penjualan \\
\hline
\end{tabular}

Sumber: Data diolah peneliti 


\section{Lampiran 2. Foto Wawancara}

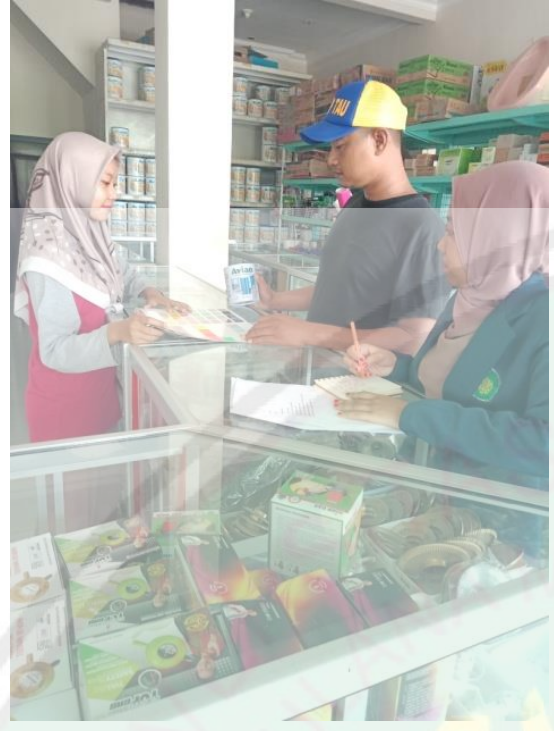

Foto: bersama bapak Dul Mukti

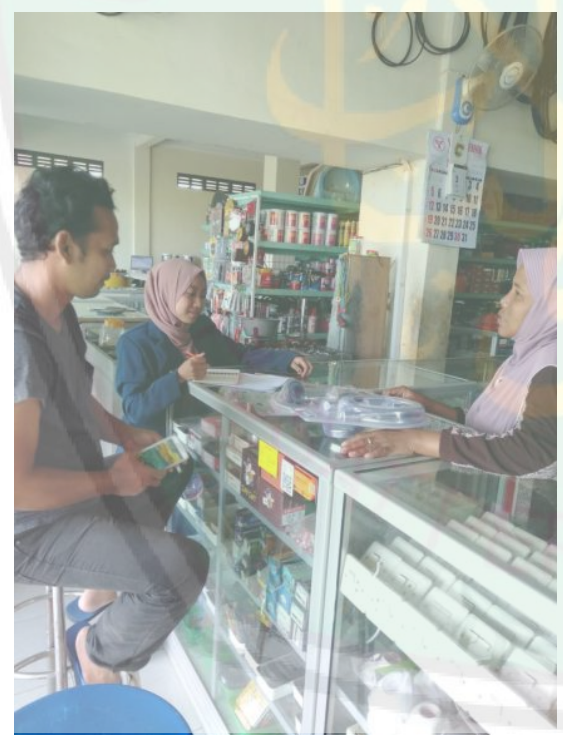

Foto: bersama bapak Puji Mulyo

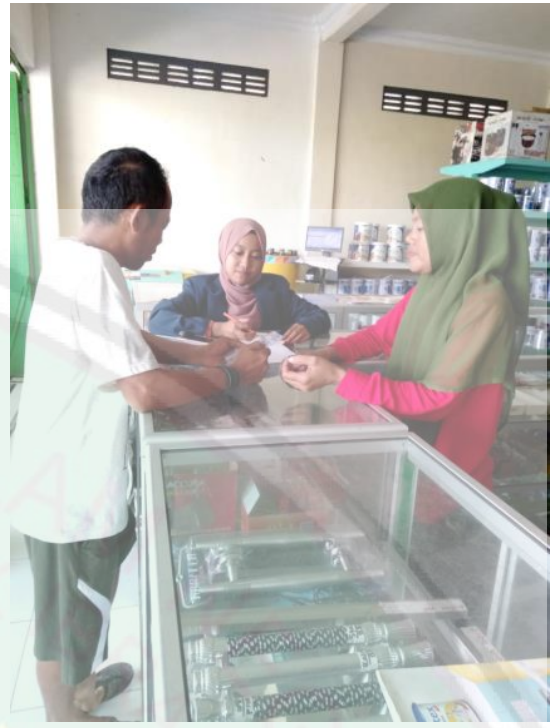

Foto: bersama bapak Aryo

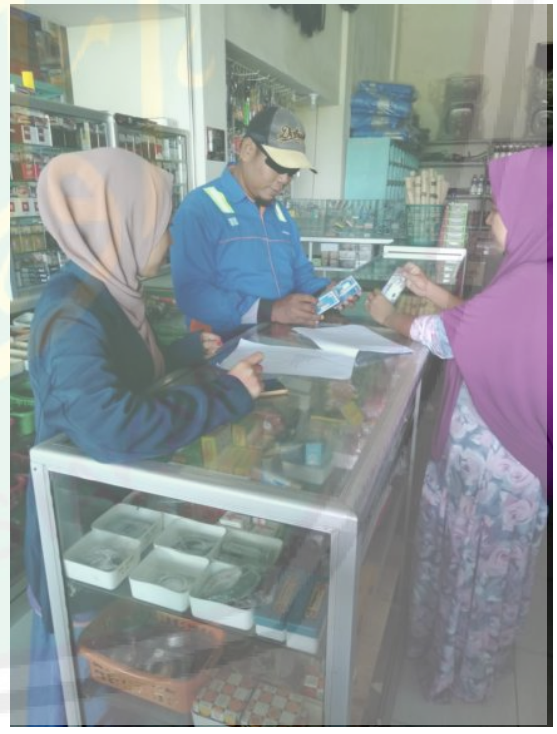

Foto: bersama bapak Sarmadi 


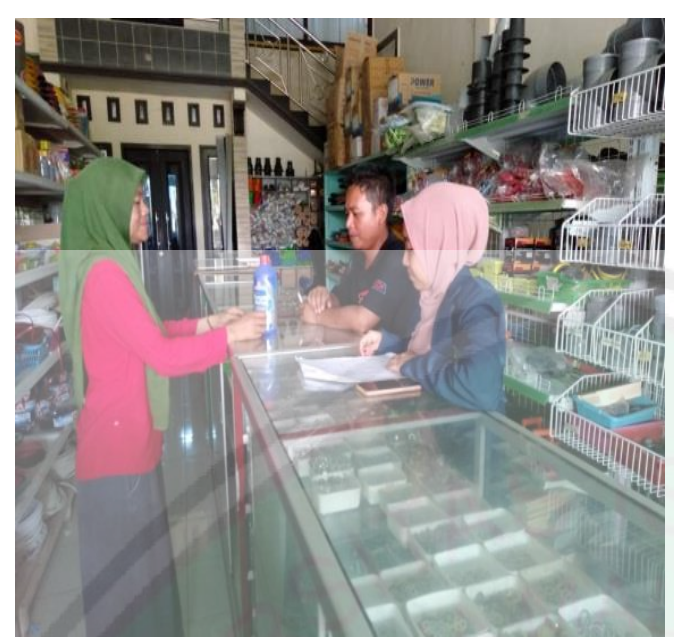

Foto: bersama bapak Anto

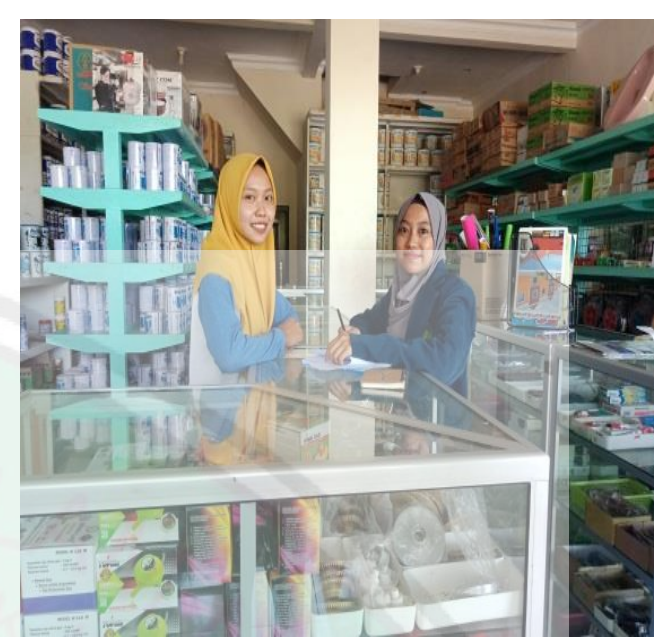

Foto: bersama mbak Hani

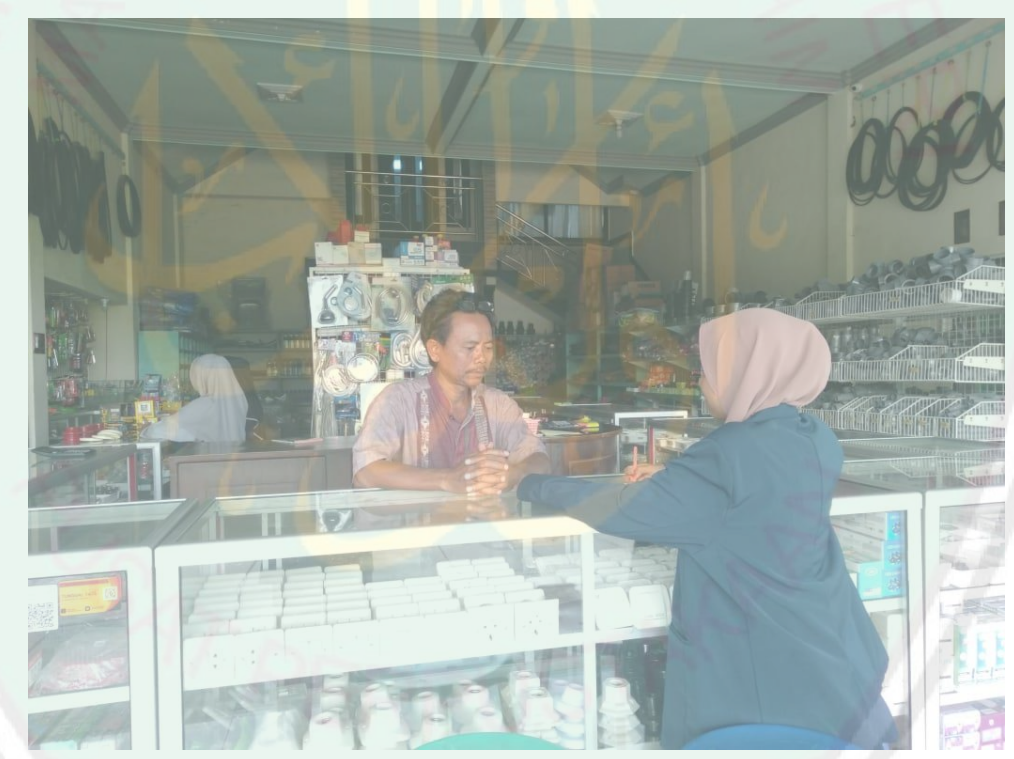

Foto: bersama bapak H.Royom 
Lampiran 3. Foto Aktivitas Toko Tunggal Tata

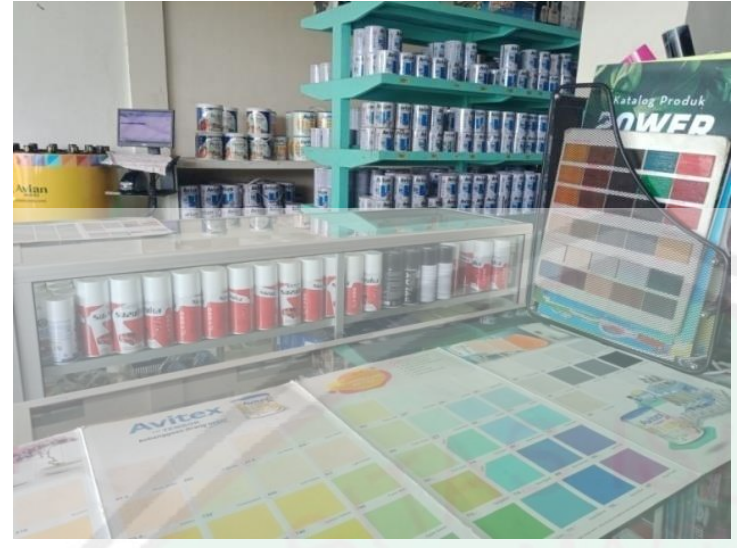

Foto: Katalog Cat

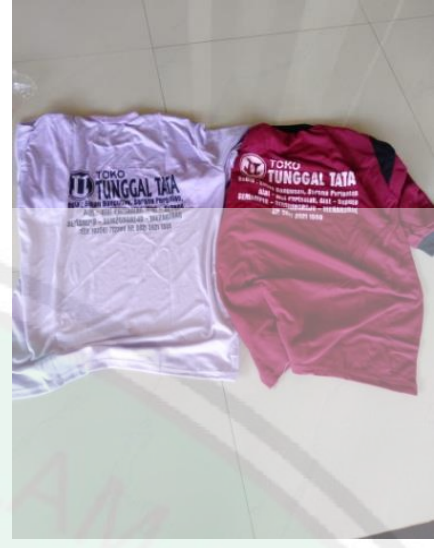

Foto: Kaos Tunggal Tata

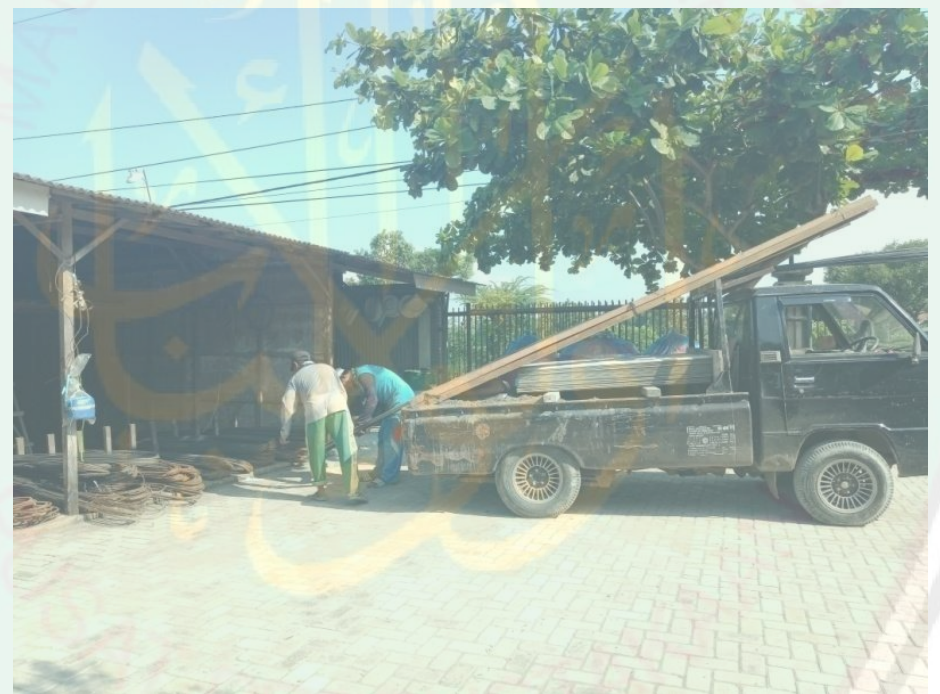

Foto: Proses pengangkutan barang 


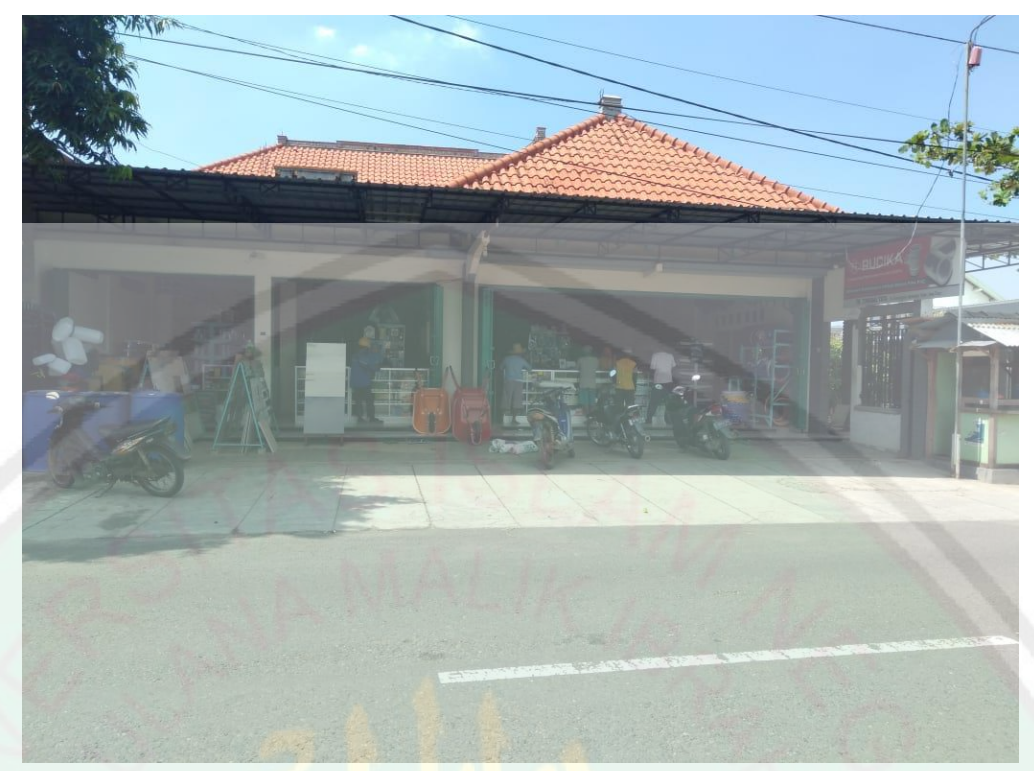

Foto: Toko Bangunan Tunggal Tata tampak depan

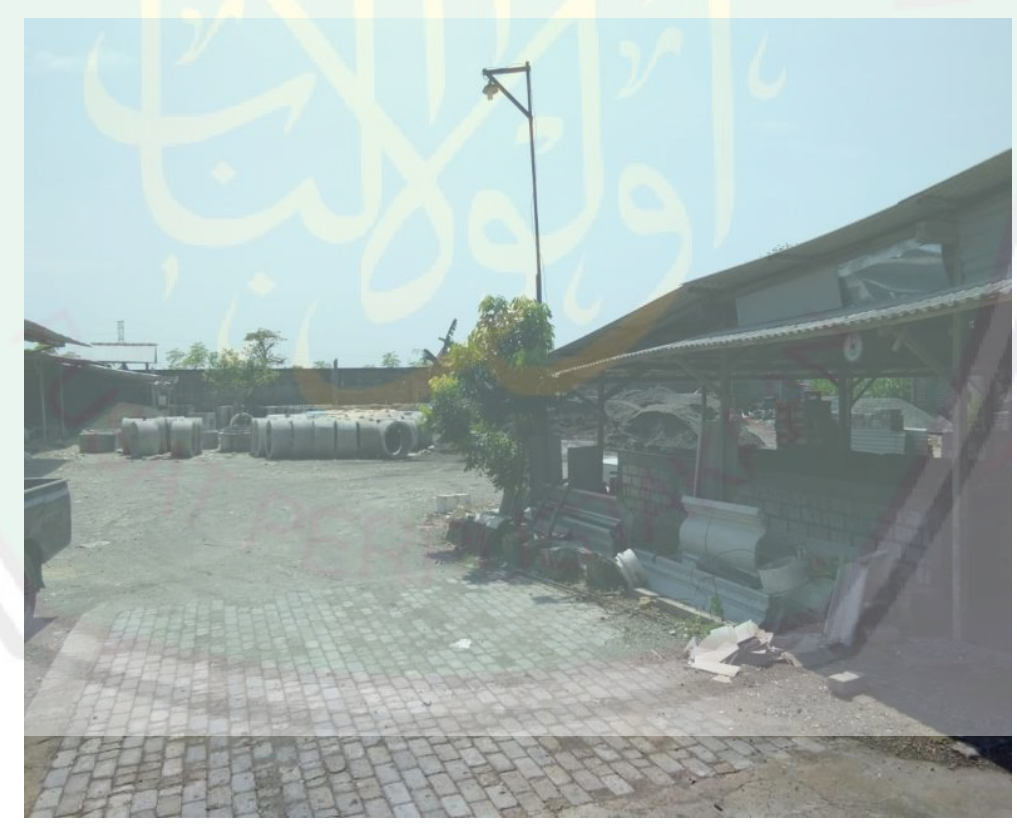

Foto: Toko Bangunan Tunggal Tata tampak Belakang 


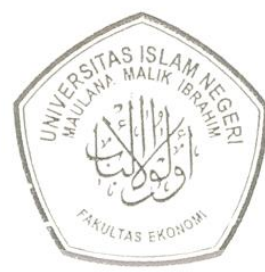

\section{KEMENTRIAN AGAMA \\ UNIVERSITAS ISLAM NEGERI \\ MAULANA MALIK IBRAHIM MALANG}

FAKULTAS EKONOMI

Jalan Gajayana 50 Malang Telepon (0341) 558881 Faksimile (0341) 558881

\section{SURAT KETERANGAN BEBAS PLAGIARISME}

Yang bertanda tangan dibawah ini :

Nama : Zuraidah, S.E., M.SA

NIP : : 197612102009122001

Jabatan : UP2M

Menerangkan bahwa mahasiswa berikut :

Nama : Siti Lailatuz Zahro'

NIM : 15510028

Handphone : 082231649636

Konsentrasi : Pemasaran

Email : Lailazahratuz@gmail.com

Judul Skripsi : Implementasi Bauran Promosi Dalam Upaya Meningkatkan Volume Penjualan pada Toko Bangunan Tunggal Tata di Tuban Jawa Timur

Menerangkan bahwa penulis skripsi mahasiswa tersebut di nyatakan $\boldsymbol{B E} \boldsymbol{B} \boldsymbol{A S}$ PLAGIARISME dari TURNITIN dengan nilai Originaly report:

\begin{tabular}{|c|c|c|c|}
\hline $\begin{array}{c}\text { SIMILARTY } \\
\text { INDEX }\end{array}$ & $\begin{array}{c}\text { INTERNET } \\
\text { SOURCES }\end{array}$ & PUBLICATION & $\begin{array}{c}\text { STUDENT } \\
\text { PAPER }\end{array}$ \\
\hline $24 \%$ & $20 \%$ & $3 \%$ & $19 \%$ \\
\hline
\end{tabular}

Demikian surat pernyataan ini dibuat dengan sebenar-benarnya dan di berikan kepada yang bersangkutan untuk dipergunakan sebagaimana mestinya.

Malang, 11 April 2019

UP2M

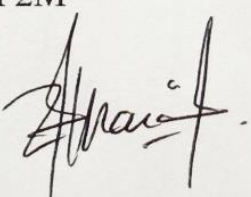

Zuraidah, S.E., M.SA

197612102009122001 
SKRIPSI

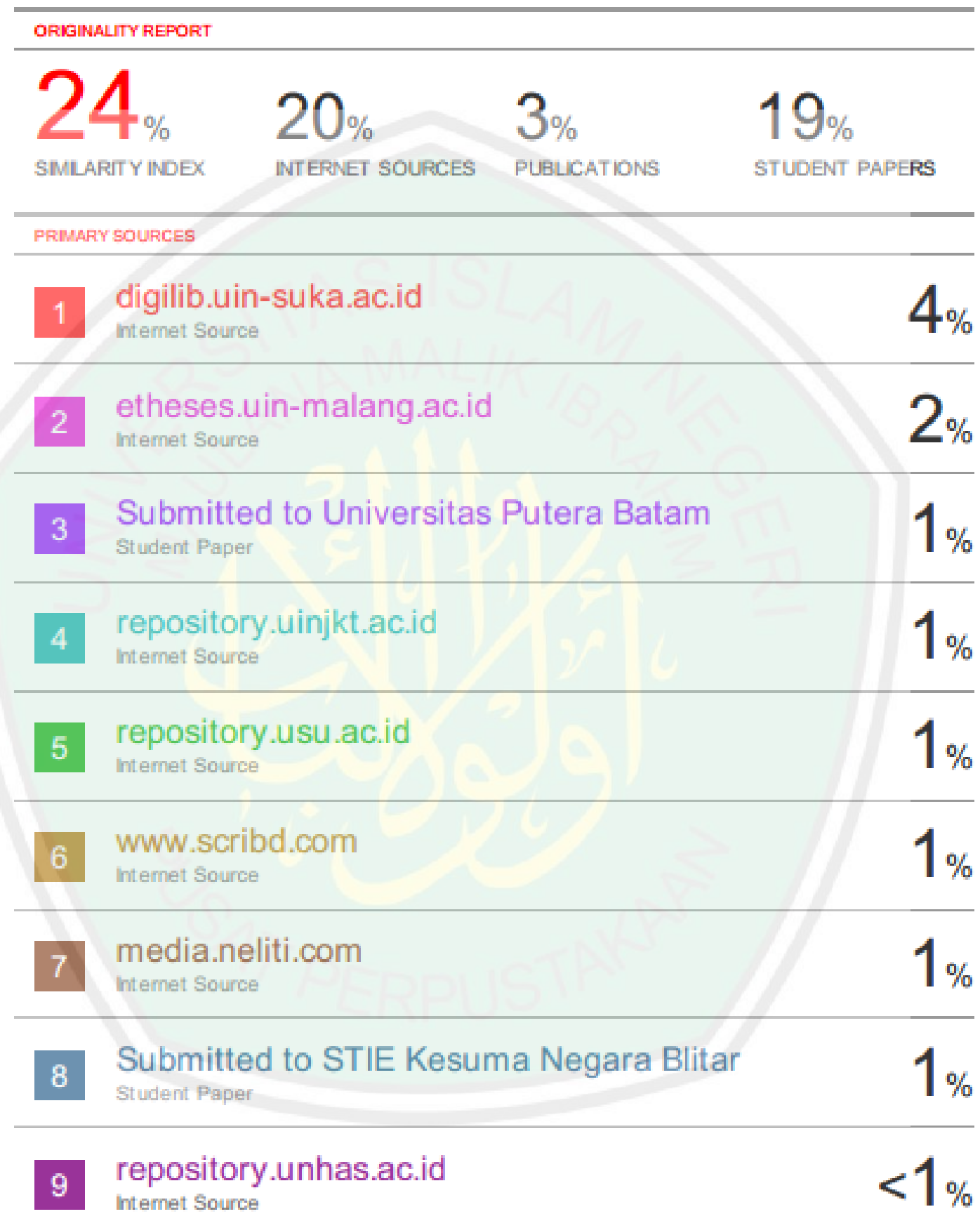




\section{0}

Submitted to Universitas Negeri Surabaya The State University of Surabaya

$<1 \%$ Student Paper

\begin{tabular}{lll}
\hline 11 & $\begin{array}{l}\text { repository.uin-malang.ac.id } \\
\text { Intemet Source }\end{array}$ & $<1 \%$ \\
\hline 12 & $\begin{array}{l}\text { Submitted to Universitas Muria Kudus } \\
\text { Student Paper }\end{array}$ & $<1 \%$ \\
\hline 13 & $\begin{array}{l}\text { studentjournal.petra.ac.id } \\
\text { Intemet Source }\end{array}$ & $<1 \%$ \\
\hline 14 & $\begin{array}{l}\text { library.binu s.ac.id } \\
\text { Intemet Source }\end{array}$ & $<1 \%$ \\
\hline 15 & $\begin{array}{l}\text { syukrahamna.blogspot.com } \\
\text { intemet Source }\end{array}$ & $<1 \%$ \\
\hline 16 & $\begin{array}{l}\text { Submitted to International Islamic University } \\
\text { Malaysia } \\
\text { Student Paper }\end{array}$ & $<1 \%$ \\
\hline 17 & $\begin{array}{l}\text { adoc.tips } \\
\text { Intemet Source }\end{array}$ & $<1 \%$ \\
\hline 18 & $\begin{array}{l}\text { Submitted to iGroup } \\
\text { Student Paper }\end{array}$ & $<1 \%$ \\
\hline 19 & $\begin{array}{l}\text { Submitted to Universitas Pendidikan Indonesia } \\
\text { Student Paper }\end{array}$ & $<1 \%$ \\
\hline 20 & $\begin{array}{l}\text { Submitted to Universitas Jenderal Soedirman } \\
\text { Student Paper }\end{array}$ & $<1 \%$ \\
\hline
\end{tabular}




\begin{tabular}{lll}
\hline 21 & $\begin{array}{l}\text { pa-sijunjung.go.id } \\
\text { intemet Source }\end{array}$ & $<1 \%$ \\
\hline 22 & $\begin{array}{l}\text { pt.scribd.com } \\
\text { Internet Source }\end{array}$ & $<1 \%$ \\
\hline 23 & $\begin{array}{l}\text { id.scribd.com } \\
\text { internet Source }\end{array}$ & $<1 \%$ \\
\hline 24 & $\begin{array}{l}\text { Submitted to Universitas Islam Indonesia } \\
\text { Student Paper }\end{array}$ & $<1 \%$ \\
\hline 25 & $\begin{array}{l}\text { Submitted to Politeknik Negeri Bandung } \\
\text { Student Paper }\end{array}$ & $<1 \%$ \\
\hline 26 & $\begin{array}{l}\text { Submitted to Universitas Muhammadiyah } \\
\text { Surakarta } \\
\text { Student Paper }\end{array}$ & $<1 \%$ \\
\hline 27 & $\begin{array}{l}\text { repository.unpas.ac.id } \\
\text { intemet Source }\end{array}$ & $<1 \%$ \\
\hline 28 & $\begin{array}{l}\text { docplayer.info } \\
\text { intemet Source }\end{array}$ & $<1 \%$ \\
\hline 29 & $\begin{array}{l}\text { Submitted to Universitas Diponegoro } \\
\text { Student Paper }\end{array}$ & $<1 \%$ \\
\hline 30 & $\begin{array}{l}\text { repository.ar-raniry.ac.id } \\
\text { intemet Source }\end{array}$ & $<1 \%$ \\
\hline 31 & $\begin{array}{l}\text { wwww.alquranpedia.org } \\
\text { intemet Source }\end{array}$ & $<1 \%$ \\
\hline
\end{tabular}




\begin{tabular}{|c|c|c|}
\hline 32 & $\begin{array}{l}\text { idr.uin-antasari.ac.id } \\
\text { Internet Source }\end{array}$ & $<1 \%$ \\
\hline 33 & $\begin{array}{l}\text { anzdoc.com } \\
\text { intemet Source }\end{array}$ & $<$ \\
\hline 34 & $\begin{array}{l}\text { www.slideshare.net } \\
\text { Intemet source }\end{array}$ & \\
\hline 35 & $\begin{array}{l}\text { repository.iainpurwokerto.ac.id } \\
\text { Internet Source }\end{array}$ & \\
\hline 36 & $\begin{array}{l}\text { repository.radenintan.ac.id } \\
\text { Internet Source }\end{array}$ & \\
\hline 37 & $\begin{array}{l}\text { eprints.uny.ac.id } \\
\text { intemet Source }\end{array}$ & \\
\hline 38 & $\begin{array}{l}\text { repo.iain-tulungagung.ac.id } \\
\text { Internet Source }\end{array}$ & \\
\hline 39 & $\begin{array}{l}\text { Submitted to Fakultas Ekonomi Universitas } \\
\text { Indonesia } \\
\text { Student Paper }\end{array}$ & \\
\hline 40 & $\begin{array}{l}\text { docobook.com } \\
\text { intemet Source }\end{array}$ & \\
\hline 41 & $\begin{array}{l}\text { Submitted to State Islamic University of } \\
\text { Alauddin Makassar } \\
\text { Student Paper }\end{array}$ & \\
\hline & $\begin{array}{l}\text { Submitted to STIE Kesatuan Bogor } \\
\text { Student Paper }\end{array}$ & \\
\hline
\end{tabular}




\begin{tabular}{|c|c|c|}
\hline 43 & $\begin{array}{l}\text { id.123dok.com } \\
\text { internet Source }\end{array}$ & $<1 \%$ \\
\hline 44 & $\begin{array}{l}\text { princessleejinki.blogspot.com } \\
\text { Intermet Source }\end{array}$ & $\%$ \\
\hline 45 & $\begin{array}{l}\text { Submitted to Binus University International } \\
\text { Student Paper }\end{array}$ & \\
\hline 46 & $\begin{array}{l}\text { es.scribd.com } \\
\text { Intemet Source }\end{array}$ & \\
\hline 47 & $\begin{array}{l}\text { eprints.walisongo.ac.id } \\
\text { Internet Source }\end{array}$ & \\
\hline 48 & $\begin{array}{l}\text { repository.widyatama.ac.id } \\
\text { internet Source }\end{array}$ & \\
\hline 49 & $\begin{array}{l}\text { thesis.binus.ac.id } \\
\text { internet Source }\end{array}$ & \\
\hline 50 & $\begin{array}{l}\text { Submitted to Sekolah Tinggi Pariwisata } \\
\text { Bandung } \\
\text { Student Paper }\end{array}$ & \\
\hline 51 & $\begin{array}{l}\text { azzaqun.blogspot.com } \\
\text { Intemet Source }\end{array}$ & \\
\hline 52 & $\begin{array}{l}\text { Submitted to UIN Syarif Hidayatullah Jakarta } \\
\text { Student Paper }\end{array}$ & $<1 \%$ \\
\hline 53 & $\begin{array}{l}\text { Submitted to Universitas Brawijaya } \\
\text { Student Paper }\end{array}$ & \\
\hline
\end{tabular}

Submitted to Universitas Negeri Jakarta 


\section{Submitted to STIE Perbanas Surabaya}

Student Paper

56 semangatpembaharuan.wordpress.com

internet Source

57 ariplie.blogspot.com

Internet Source

58 www.docstoc.com

internet Source

59 Submitted to Universiti Sains Malaysia Student Paper

60 cahayakhaeroni.blogspot.com

61 Submitted to Universitas Negeri Makassar Student Paper

62 Submitted to Universitas Sebelas Maret Student Paper

63 Submitted to Surabaya University Student Paper

64 Submitted to President University

65 skripsiekonomi1.blogspot.com 


\begin{tabular}{|c|c|}
\hline 66 & $\begin{array}{l}\text { Submitted to Sriwijaya University } \\
\text { Student Paper }\end{array}$ \\
\hline 67 & $\begin{array}{l}\text { fadhilashari01.blogspot.com } \\
\text { Intemet Source }\end{array}$ \\
\hline 68 & $\begin{array}{l}\text { administrasibisnis.studentjournal.ub.ac.id } \\
\text { Internet Source }\end{array}$ \\
\hline & $\begin{array}{l}\text { Yoga Adiyanto, Yuda Supriatna. "Analisis } \\
\text { Strategi Promosi Dalam Pengembangan } \\
\text { Pariwisata Di Kabupaten Lebak Banten", Sains } \\
\text { Manajemen, } 2019 \\
\text { Publication }\end{array}$ \\
\hline 70 & $\begin{array}{l}\text { Raditya Kurniawan. "PENGARUH BIAYA } \\
\text { BAHAN BAKU TERHADAP VOLUME } \\
\text { PENJUALAN PADA INDUSTRI GAMELAN } \\
\text { "MITRA JAYA" DI DESA KARANG REJO } \\
\text { KECAMATAN KARANG REJO KABUPATEN } \\
\text { MAGETAN", EQUILIBRIUM : Jurnal IImiah } \\
\text { Ekonomi dan Pembelajarannya, } 2014 \\
\text { Publication }\end{array}$ \\
\hline 7 & $\begin{array}{l}\text { jurnalmahasiswa.unesa.ac.id } \\
\text { intemet Source }\end{array}$ \\
\hline 72 & $\begin{array}{l}\text { portal.widyamandala.ac.id } \\
\text { internet Source }\end{array}$ \\
\hline 73 & $\begin{array}{l}\text { journal.uad.ac.id } \\
\text { Intemet Source }\end{array}$ \\
\hline
\end{tabular}


74 Submitted to UIN Maulana Malik Ibrahim Malang

Student Paper

\begin{tabular}{|c|c|c|}
\hline 75 & $\begin{array}{l}\text { destriana-fauzie.blogspot.com } \\
\text { Internet Source }\end{array}$ & $<1 \%$ \\
\hline 76 & $\begin{array}{l}\text { uad.portalgaruda.org } \\
\text { intemet Source }\end{array}$ & \\
\hline 77 & $\begin{array}{l}\text { text-id.123dok.com } \\
\text { intemet Source }\end{array}$ & \\
\hline 78 & $\begin{array}{l}\text { vdocuments.site } \\
\text { Internet Source }\end{array}$ & \\
\hline 79 & $\begin{array}{l}\text { e-journal.uajy.ac.id } \\
\text { Intemet Source }\end{array}$ & \\
\hline 80 & $\begin{array}{l}\text { Submitted to Universitas Andalas } \\
\text { Student Paper }\end{array}$ & \\
\hline 81 & $\begin{array}{l}\text { familyrumaday.blogspot.com } \\
\text { Internet Source }\end{array}$ & \\
\hline 82 & $\begin{array}{l}\text { ariebagoezt.blogspot.com } \\
\text { Intemet Source }\end{array}$ & \\
\hline 83 & $\begin{array}{l}\text { ftp.unpad.ac.id } \\
\text { intemet Source }\end{array}$ & \\
\hline 84 & $\begin{array}{l}\text { Submitted to Universitas Jember } \\
\text { Student Paper }\end{array}$ & \\
\hline
\end{tabular}

eprints.undip.ac.id 


\begin{tabular}{lll}
\hline 86 & $\begin{array}{l}\text { garuda.ristekdikti.go.id } \\
\text { intemet Source }\end{array}$ & $<1 \%$ \\
\hline 87 & $\begin{array}{l}\text { eprints.stainkudus.ac.id } \\
\text { Intemet Source }\end{array}$ & $<1 \%$ \\
\hline 88 & $\begin{array}{l}\text { afifhariz.blogspot.com } \\
\text { intemet Source }\end{array}$ & $<1 \%$ \\
\hline 89 & $\begin{array}{l}\text { repositori.uin-alauddin.ac.id } \\
\text { intemet Source }\end{array}$ & $<1 \%$ \\
\hline 90 & $\begin{array}{l}\text { Submitted to Universitas Warmadewa } \\
\text { Student Paper }\end{array}$ & $<1 \%$ \\
\hline 91 & $\begin{array}{l}\text { nurazizahaziz.web.unej.ac.id } \\
\text { internet Source }\end{array}$ & $<1 \%$ \\
\hline 92 & $\begin{array}{l}\text { eprints.uns.ac.id } \\
\text { Intemet Source }\end{array}$ & $<1 \%$ \\
\hline 93 & $\begin{array}{l}\text { eprints.upnjatim.ac.id } \\
\text { intemet Source }\end{array}$ & $<1 \%$ \\
\hline 94 & $\begin{array}{l}\text { ytnarf.blogspot.com } \\
\text { intemet Source }\end{array}$ & $<1 \%$ \\
\hline 95 & $\begin{array}{l}\text { Submitted to Universitas Islam Malang } \\
\text { Student Paper }\end{array}$ & $<1 \%$ \\
\hline 96 & $\begin{array}{l}\text { johannessimatupang.wordpress.com } \\
\text { internet Source }\end{array}$ & $<1 \%$ \\
\hline
\end{tabular}




\begin{tabular}{|c|c|}
\hline 97 & $\begin{array}{l}\text { library.upnvj.ac.id } \\
\text { Intemet Source }\end{array}$ \\
\hline 98 & $\begin{array}{l}\text { sungebanjur.blogspot.com } \\
\text { Intemet Source }\end{array}$ \\
\hline 99 & $\begin{array}{l}\text { repository.uinsu.ac.id } \\
\text { internet Source }\end{array}$ \\
\hline 100 & $\begin{array}{l}\text { Submitted to Unika Soegijapranata } \\
\text { Student Paper }\end{array}$ \\
\hline 101 & $\begin{array}{l}\text { vivekavana.com } \\
\text { internet Source }\end{array}$ \\
\hline 102 & $\begin{array}{l}\text { repository.fisip-untirta.ac.id } \\
\text { Intemet Source }\end{array}$ \\
\hline 103 & $\begin{array}{l}\text { azimanaf.blogspot.com } \\
\text { internet Source }\end{array}$ \\
\hline 104 & $\begin{array}{l}\text { fridaus.org } \\
\text { Internet Source }\end{array}$ \\
\hline 105 & $\begin{array}{l}\text { airminumfitaqua.blogspot.com } \\
\text { Internet Source }\end{array}$ \\
\hline 106 & $\begin{array}{l}\text { Submitted to Universitas Islam Bandung } \\
\text { Student Paper }\end{array}$ \\
\hline 107 & $\begin{array}{l}\text { Submitted to Doral Academy High School } \\
\text { Student Paper }\end{array}$ \\
\hline
\end{tabular}

108 Submitted to UIN Sunan Gunung DJati 


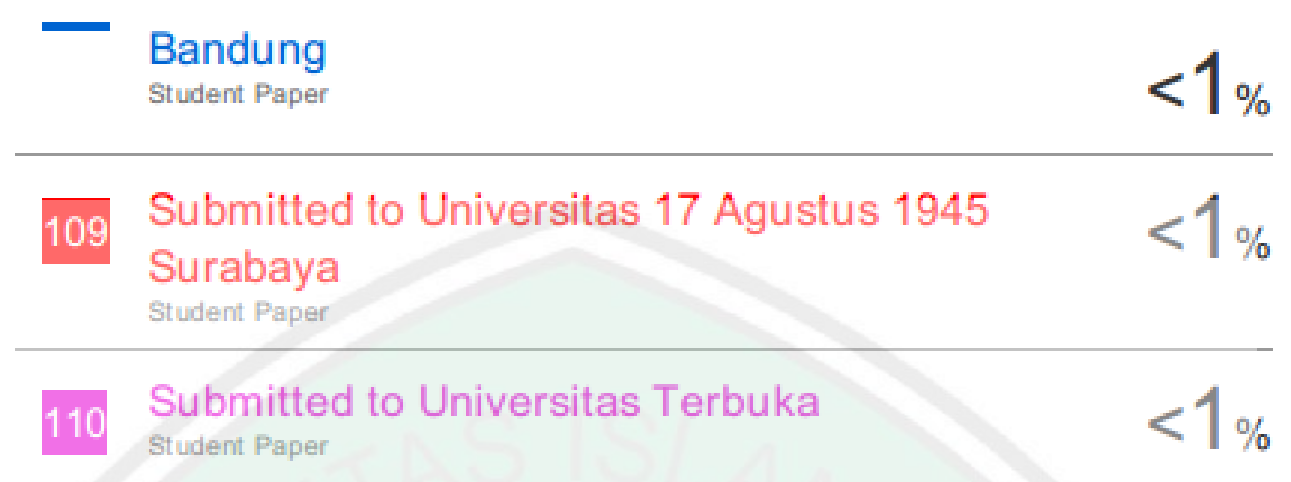

\begin{tabular}{ll|l} 
Exclude quotes & Off & Exclude matches \\
Exclude biblography & Off &
\end{tabular}




\section{BUKTI KONSULTASI}

Nama

NIM/Jurusan

Pembimbing

Judul Skripsi
: Siti Lailatuz Zahro'

: 15510028/Manajemen

: Fani Firmansyah, SE., MM

: Implementasi Bauran Promosi Dalam Upaya

Meningkatkan Volume Penjualan Pada Toko Bangunan

Tunggal Tata di Tuban Jawa Timur

\begin{tabular}{|c|c|c|c|}
\hline No. & Tanggal & Materi Konsultasi & Tanda Tangan Pembimbing \\
\hline 1. & 04 September 2018 & Judul Skripsi & 1. \\
\hline 2. & 08 Februari 2019 & Proposal & 2. \\
\hline 3. & 22 Februari 2019 & Proposal & \\
\hline 4. & 26 Februari 2019 & Acc Proposal & \\
\hline 5. & 10 Mei 2019 & Pembahasan Bab IV & 5. \\
\hline 6. & 13 Mei 2019 & Bab IV-V & \\
\hline 7. & 13 Mei 2019 & Acc Skripsi & 7. \\
\hline
\end{tabular}

Malang, 13 Mei 2019

Mengetahui,

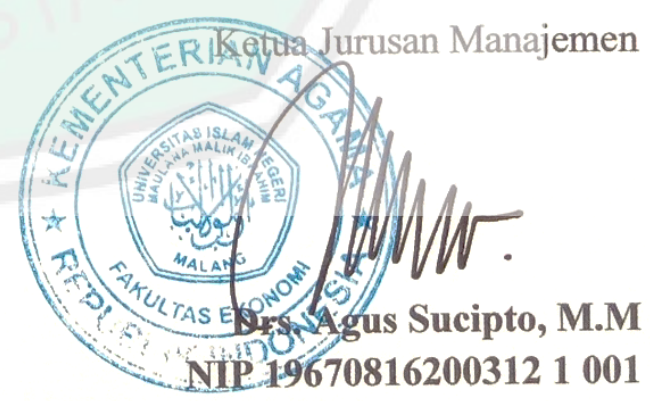




\section{BIODATA PENELITI}

\begin{tabular}{|c|c|}
\hline Nama Lengkap & : Siti Lailatuz Zahro’ \\
\hline Tempat, Tanggal Lahir & : Tuban, 25 September 1997 \\
\hline Alamat Asal & Dsn.Semampir Ds.Sembungrejo Merakurak Tuban \\
\hline Alamat Tinggal & : Jl. Joyosuko no.60A Lowokwaru Malang \\
\hline Telepon/HP & : 082231649636 \\
\hline E-Mail & : lailazahratuz@gmail.com \\
\hline \multicolumn{2}{|l|}{ Pendidikan formal } \\
\hline $2001-2003$ & : TK Darma Wanita Senori Merakurak Tuban \\
\hline 2003-2009 & : SDN Sembungrejo Merakurak Tuban \\
\hline 2009-2012 & : SMPN I Merakurak Tuban \\
\hline $2012-2015$ & : MAN Tambakberas (MAN 3) Jombang \\
\hline 2015-2019 & : Jurusan Manajemen Fakultas Ekonomi Universitas \\
\hline & Islam Negeri Maulana Malik Ibrahim Malang \\
\hline
\end{tabular}

Pendidikan Non Formal

$2015-2016$

: Program Khusus Perkuliahan Bahasa Arab UIN Maulana Malik Ibrahim Malang

2016-2017

: Eglish Language Center (ELC) UIN Maulana

Malik Ibrahim Malang

\section{Pengalaman Organisasi}

- Pengurus PMII Moh. Hatta Rayon Ekonomi UIN Maulana Malik Ibrahim Malang 2017 